\title{
USO DE PRODUTOS GLICONEOGÊNICOS NO PRÉ E PÓS- PARTO SOBRE PARÂMETROS PRODUTIVOS, REPRODUTIVOS E SANGÜÍNEO DE VACAS HOLANDESAS
}

\section{Paulo Garcez De Oliveira}

Tese apresentada à Escola Superior de Agricultura "Luiz de Queiroz", Universidade de São Paulo, para obtenção do título de Doutor em Agronomia, Área de Concentração: Ciência Animal e Pastagens.

PIR A C ICABA

Estado de São Paulo - Brasil

Julho - 2002 


\section{USO DE PRODUTOS GLICONEOGÊNICOS NO PRÉ E PÓS- PARTO SOBRE PARÂMETROS PRODUTIVOS, REPRODUTIVOS E SANGÜÍNEO DE VACAS HOLANDESAS}

\section{Paulo Garcez De Oliveira}

Médico Veterinário

Orientador: Prof. Dr. ALEXANDRE VAZ PIRES

Tese apresentada à Escola Superior de Agricultura "Luiz de Queiroz", Universidade de São Paulo, para obtenção do título de Doutor em Agronomia, Área de Concentração: Ciência Animal e Pastagens.

PIR A C I C A B A

Estado de São Paulo - Brasil

Julho -2002 


\title{
Dados Internacionais de Catalogação na Publicação (CIP)
} DIVISÃO DE BIBLIOTECA E DOCUMENTAÇÃO - ESALQ/USP

\author{
Oliveira, Paulo Garcezde \\ Uso de produtos glic oneogênic os no pré e pós-parto sobre parâmetros \\ produtivos, reprodutiv ose sangüíneo de vacas holandesas/ Paulo Garcez \\ de Oliveira. - - Piracic aba, 2002. \\ $120 \mathrm{p}$. \\ Tese (doutorado) - Escola Superior de Agricultura Luiz de Queiroz, 2002. \\ Bibliografia. \\ 1. Pós-parto a nimal2. Reprodução animal 3. Suplementos energétic os \\ para animais 4 . Vaca holandesa I. Título
}

CDD 636.234

"Permitida a cópia total ou parcial deste documento, desde que citada a fonte - O autor" 


\section{DEDICATÓRIA}

À minha esposa Mary, as filhas Paula, Mariane e Aline pelo apoio e compreensão das muitas horas de separação de nosso convívio, dedico este trabalho. 


\section{AGRADECIMENTOS}

À Deus pela oportunidade da vida, pela sua contínua presença e direção em minha vida, em minha família e na realização deste trabalho. Gratidão especial pelo seu amor incondicional e pelas promessas futuras, principalmente aquela de I Coríntios 2:9 que diz: "as coisas que o olho não viu, o ouvido não ouviu e que jamais passaram pelo pensamento do homem são as coisas que Deus preparou para aqueles que o amam".

À Escola Superior de Agricultura "Luiz de Queiroz" (ESALQ-USP) através do Departamento de Produção animal, a oportunidade e apoio da realização deste curso.

À Coordenação de Aperfeiçoamento de Pessoas de Nível Superior (CAPES) pela bolsa concedida.

À Fundação de Amparo à Pesquisa do Estado de São Paulo (FAPESP), pela concessão parcial do financiamento deste projeto.

Ao Instituto Adventista de Ensino por ter um dia me aceitado como estudante sem nenhuma condição financeira e ter transmitido valores morais fundamentais à vida de um ser humano.

Aos proprietários da Fazenda Pinhalzinho e ao Centro Universitário Adventista por ceder os animais para a realização do experimento.

Ao Prof. Dr. Alexandre Vaz Pires, pela orientação, confiança, amizade e exemplo de humildade.

Aos demais professores do Departamento, pelos ensinamentos e convívio. 
Ao Laboratório de Química Analítica do Centro de Energia Nuclear para Agricultura (CENA), especialmente ao Prof. Dr. Boaventura, à Dra. Patrícia e à doutoranda Cherrine pela cessão do laboratório e orientação de parte das análises laboratoriais.

Ao Prof. Dr. Paulo Mazza e doutoranda Paula Meyer pela amizade e auxílio nas análises estatísticas.

Ao colega e amigo Elias Villarreta, pelo convívio na FEOB e pelo excelente auxílio na realização deste trabalho.

À sobrinha e acadêmica do curso de Medicina Veterinária Ligiane Leme, pelo auxílio nas análises laboratoriais e tabulação dos dados.

Aos funcionários Sr. Anísio, Roque e Jair da Fazenda Pinhalzinho, Paulo Rafael, André Felipe, Gilmar Keffler e Amós do Nascimento do Instituto Adventista de Ensino pela indispensável ajuda na realização do experimento.

Aos meus familiares que, de uma forma direta ou indireta, contribuíram para que este trabalho pudesse ser executado.

À Dra Carla Nussio, ao Ms. Renato e ao técnico César do Laboratório de Bromatologia da ESALQ pelo auxílio de parte das análises laboratoriais.

Ao amigo e companheiro Juliano (GOMÃO) pelo apoio e auxílio, ao Reinaldo pela amizade, ao Vicente "S" pelo convívio, aos demais colegas da pós-graduação pelos momentos que compartilhamos juntos.

À todas as pessoas não mencionadas que, de uma forma ou de outra, participaram e apoiaram na conclusão do curso. 


\section{SUMÁRIO}

Página

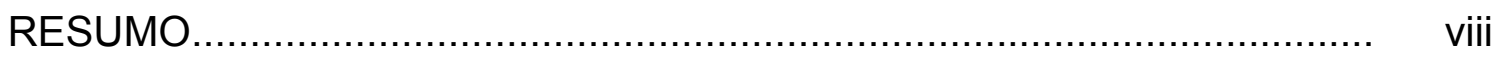

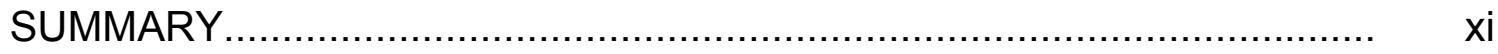

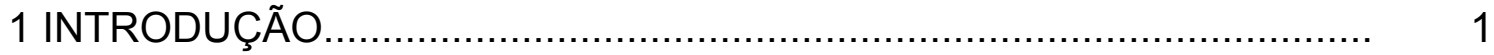

2 REVISÃO DE LITERATURA.........................................................

2.1 Desempenho reprodutivo............................................................. 4

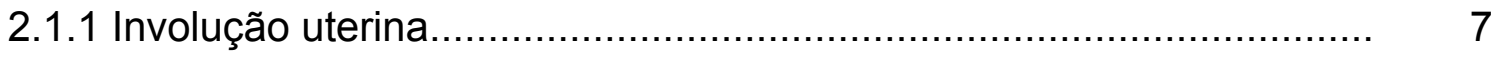

2.1.2 Período de serviço................................................................... 10

2.1.3 Balanço energético................................................................. 14

2.1.4 Animais de alta produção de leite................................................ 15

2.2 Condição corporal e reprodução....................................................... 22

2.3 Distúrbios metabólicos................................................................ 26

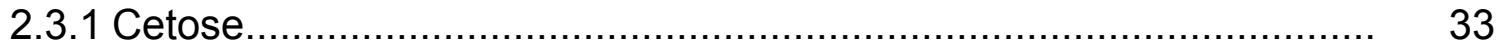

2.4 Período de transição.............................................................. 39

2.4.1 Suplementação com produtos energéticos no período de transição.. $\quad 42$

3 MATERIAL E MÉTODOS.............................................................. 49

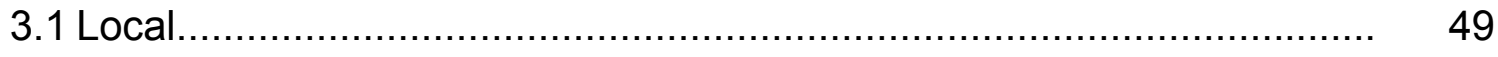

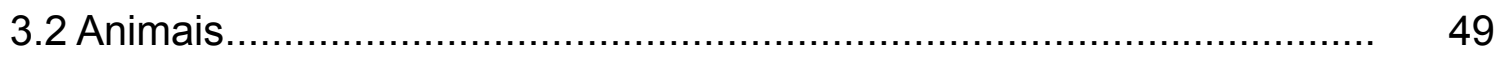

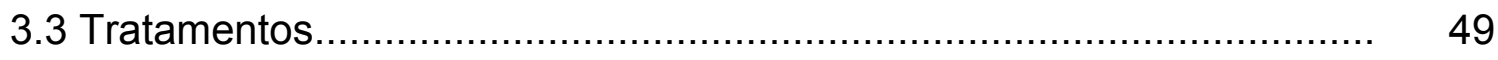

3.4 Variáveis avaliadas.............................................................. 51

3.4.1 Escore de condição corporal.................................................... 51

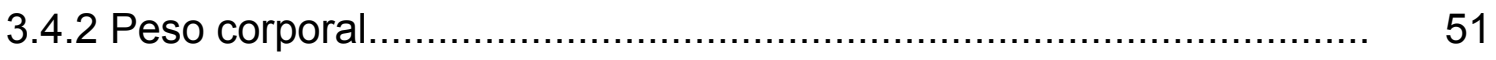

3.4.3 Produção de leite .................................................................. 52 
3.4.4 Parâmetro sangüíneo......................................................... 52

3.4.5 Parâmetros reprodutivos............................................................... 52

3.4.6 Amostragem de alimento............................................................ 52

3.5 Análise estatística..................................................................... 53

4 RESULTADOS E DISCUSSÃO................................................. 55

4.1 Condição corporal................................................................... 55

4.1.1 Escore de condição corporal ...................................................... 55

4.1.2 Variação no escore de condição corporal........................................ 60

4.2 Peso dos animais.................................................................... 61

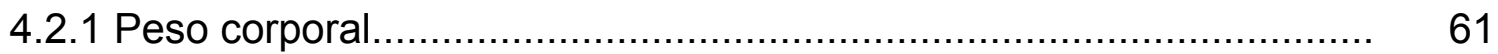

4.2.2 Variação diária do peso corporal.................................................... 64

4.3 Produção de leite....................................................................... 67

4.4 Eficiência reprodutiva............................................................. 70

4.4.1 Dias para ocorrência do primeiro cio detectável pós-parto................. 70

4.4.2 Número de serviços por concepção................................................ 74

4.4.3 Período de serviço................................................................. 77

4.5 Parâmetro sangüíneo.............................................................. 80

4.5.1 Ácidos graxos livres (AGL) …................................................ 80

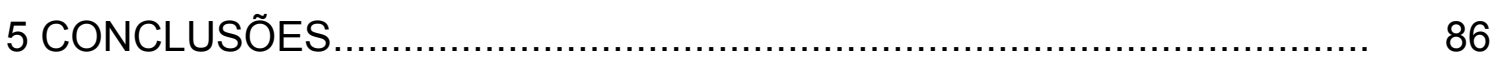

REFERÊNCIAS BIBLIOGRÁFICAS.................................................. 87 


\title{
USO DE PRODUTOS GLICONEOGÊNICOS NO PRÉ E PÓS-PARTO SOBRE PARÂMETROS PRODUTIVOS, REPRODUTIVOS E SANGÜÍNEO DE VACAS HOLANDESAS
}

\author{
Autor: PAULO GARCEZ DE OLIVEIRA \\ Orientador: Prof. Dr. ALEXANDRE VAZ PIRES
}

\section{RESUMO}

Este experimento foi realizado com objetivo de se avaliar os efeitos da suplementação com os energéticos propileno glicol, propionato de cálcio e "Dairy Power Drench ${ }^{\circledR}$ " no período pré e pós-parto de vacas leiteiras sobre: a) variação do escore de condição corporal (ECC); b) variação de peso; c) produção de leite, d) parâmetros de eficiência reprodutiva e e) concentração plasmática dos ácidos graxos livres (AGL). Para este estudo, foram utilizadas 165 fêmeas da raça Holandesa (132 vacas e 33 novilhas) de dois rebanhos comerciais. As parições destes animais ocorreram entre 15 de março a 15 de junho de 1999. Os animais foram distribuídos em quatro grupos: grupo CControle com 41 animais; grupo DR- com 42 animais que receberam 3 aplicações de "Dairy Power Drench®" no pós-parto; grupo PC- com 39 animais que receberam $500 \mathrm{~g}$ diários de propionato de cálcio, iniciando em média 11 dias antes da data do parto até 49 dias pós-parto; grupo PG com 43 animais que receberam $500 \mathrm{~mL}$ diários de propileno glicol, iniciando em média 13 dias antes da data do parto e continuando até o $51^{\circ}$ dia pós-parto. A avaliação da 
condição corporal foi feita semanalmente, usando-se a escala de 1 a 5 e o peso foi aferido com auxílio da fita barimétrica, ambos no mesmo dia e pela mesma pessoa. A mensuração individual da produção de leite e a colheita de sangue para avaliação da concentração de ácidos graxos livres foram realizados semanalmente. O parâmetro reprodutivo, dias para primeiro cio pós-parto, foi realizado por observação visual, realizada duas vezes ao dia. Os dados foram submetidos à análise de variância que separou como causas de variação efeito de tratamento e efeito dos blocos formados em função da fazenda (Fazenda $1 \mathrm{e}$ 2) e do números de partos (primíparas ou multíparas). As análises referentes aos valores de produção de leite, escore de condição corporal, peso vivo, variação diária do peso corporal e concentração de ácidos graxos livres foram acrescidos do fator medidas repetidas no tempo (semanas). A comparação entre as médias dos tratamentos foi realizada através do teste de Tukey. Não foi observado efeito de interação de tempo $x$ tratamento sobre a variável escore de condição corporal. Entretanto, houve uma tendência $(P<0,08)$ de efeito de tratamento e efeito quadrático de tempo $(P<0,01)$. As vacas que receberam "Drench" tenderam a apresentar uma condição corporal 6\% superior ao grupo que recebeu propileno glicol. Já a variação da condição corporal (ECC6 ECC1) não sofreu efeito de tratamento. Para o peso corporal e variação diária de peso não foi observado efeito dos tratamentos, nem interação entre tempo $x$ tratamento. Entretanto, sofreram efeito de tempo de comportamento quadrático ( $P<0,01$ e $P<0,05$, respectivamente). As vacas produziram em média $27,3 \mathrm{~kg}$ de leite/dia, sendo observado efeito de interação tempo $x$ tratamento $(P<0,01)$ sobre esta variável. Porém, dentro de cada semana, as possíveis diferenças não foram detectadas. Os tratamentos não afetaram os parâmetros de eficiência reprodutiva. Encontrou-se em média 69,5 dias para o aparecimento do primeiro cio, 2,23 serviços/concepção e 172,6 dias para o período de serviço. As concentrações médias dos ácidos graxos livres encontradas durante o período experimental foram de 376,6 $\mu \mathrm{eq} / \mathrm{L}$, não se observando efeitos de interação tempo $x$ tratamento ou de tratamento. Porém, sofreram efeito de 
tempo $(P<0,01)$ com comportamento linear $(P<0,01)$, decrescendo $48,2 \mu \mathrm{eq} / \mathrm{L}$ por semana. 


\section{GLUCONEOGENIC SUPPLEMENTS ON PRE AND POSTPARTUM AND PRODUCTION AND REPRODUCTION TRAITS AND BLOOD METABOLITE OF HOLSTEIN COWS}

Author: PAULO GARCEZ DE OLIVEIRA Adviser: Prof. Dr. ALEXANDRE VAZ PIRES

\section{SUMMARY}

The objective of this trial was to evaluate the effects of propylene glycol, calcium propionate and "Dairy Power Drench ${ }^{\circledR}$ " supplementation on pre and postpartum period of Holstein cows. Parameters studied were: a) body condition score variation (BCS); b) body weight variation; c) milk production, d) reproduction efficiency and e) nonesterified fatty acids concentration (NEFA). One hundred and sixty and five animals were used (132 cows and 33 heifers) from two commercial herds. Parturitions started on March $15^{\text {th }}$ and ended on June $15^{\text {th }}$ of 1999 . Animals were allocated in four groups: group C- Control (41 animals); group DR- (42 animals) with administration of "Dairy Power Drench $®$ " (once a day for 3 days) during postpartum period; group PC- (39 animals) with daily administration of calcium propionate $(500 \mathrm{~g})$, starting 11 days (in average) prior to parturition and ending 49 days postpartum; group PG (43 animals) with daily administration of propylene glycol $(500 \mathrm{~mL})$, starting 13 days (in average) prior to parturition and ending 51 days postpartum. The evaluation of BCS was done weekly, using a five-point scale over values from 1 to 5 and body weight 
was also measured, on the same day, by the same person. Milk production was measured individually and blood was sampled weekly. The parameter days to postpartum first detected estrus was done visually, twice a day. Variance analysis separated as variation sources the effect of treatments and blocks in function of farms (Farm 1 and 2) and parity (primiparous or multiparous). Analyses referred to milk production, body condition score, body weight, daily variation of body weight and nonesterified fatty acids concentration were added with repeated measures factor (weeks). Treatments were compared using Tukey's test. Interaction between time (weeks) and treatment was not found for BCS, however, there was a tendency $(P<0.08)$ of treatment effect and quadratic effect of time $(P<0.01)$. Supplementation of "Drench" tended to cause a body condition score $6 \%$ higher compared to supplementation of propylene glycol. But the variation of BSC (BSC6 -BSC1) was not affected by treatments. Body weight and its variation were not affected by treatment or interaction time $\mathrm{x}$ treatment. However, there was a quadratic effect of time $(P<0.01$ and $P<0.05$, respectively). Milk production average was $27.3 \mathrm{~kg} /$ day and an interaction time $\mathrm{x}$ treatment was found $(P<0.01)$ on this parameter. But inside of each week, the possible differences were not detected. Treatments also did not affect reproductive efficiency parameters. On average, days to postpartum first detected estrus were 69.5, service/conception was 2.23 and service period was 172.6 days. Nonesterified fatty acids concentration average was $376.6 \mu \mathrm{eq} / \mathrm{L}$ and there was no effect of interaction time $x$ treatment or treatment. But there was a linear effect $(P<0.01)$, decreasing $48.2 \mu \mathrm{eq} / \mathrm{L}$ per week. 


\section{INTRODUÇÃO}

A economia de mercado nos dias atuais, a especialização de mão de obra, os altos custos fixos da produção de leite e o conhecimento advindo de pesquisas, tem feito com que os sistemas de produção de leite no mundo, tenham sofrido profundas alterações.

A comunidade européia já estabeleceu o sistema de cotas para os produtores, enquanto nos Países do terceiro mundo observa-se um crescimento de produção juntamente com o crescimento do número de animais. Entretanto, nos E.U.A., tem-se observado nos últimos 30-40 anos, um aumento significativo na produção média de leite por vaca, saindo de uma produção de $4160 \mathrm{~kg}$ na década de 50 para uma produção de $8178 \mathrm{~kg} \mathrm{em} \mathrm{1990.} \mathrm{Por} \mathrm{outro}$ lado, tem-se observado uma diminuição na eficiência reprodutiva pós-parto.

Segundo Miyoshi et al. (2001), a produção de leite nas últimas décadas tem aumentado acentuadamente como resultado de intensa seleção genética, avanço no manejo nutricional, melhora no controle de doenças e outras práticas de manejo.

A globalização da economia facilitou a comercialização de sêmen, embriões e animais, o que tem contribuído para o aumento da produção mundial de leite, principalmente o material genético de origem canadense e americano (Philipson, 1990). Alguns pontos básicos para se atingir elevada eficiência nos sistemas de produção intensiva são o uso de animais especializados, manejo sanitário, nutricional e reprodutivo o mais próximo do ideal, oferecendo condições adequadas de conforto para que os animais possam responder com altas produções. Para Nebel \& McGillard (1993), o 
manejo e o ambiente são as principais causas de variação na reprodução e produção de leite. A produção de leite e o desempenho reprodutivo ocupam os papéis mais importantes na determinação da rentabilidade dos rebanhos leiteiros (Arbel et al., 2001).

Segundo Drakcley (1998), durante o período de transição se determina a eficiência da vaca na lactação seguinte e problemas durante este período resultam em perdas de 4,5 a 9,0 kg/dia no pico de lactação, o qual representa uma perda econômica da ordem de US\$300 a US\$600 para a lactação em questão. O período de transição, segundo Schlatter (1997), varia de 3 semanas antes do parto a diferentes períodos pós-parto. Este período pós-parto pode variar de 3 semanas ou até a vaca atingir o pico de lactação, variando conforme o manejo do animal. Este período é caracterizado por grande estresse metabólico, que se manifesta por queda no consumo voluntário de alimento, intensa mobilização de reservas corporais e aumento nas suas exigências nutricionais, com reflexo na produção e reprodução.

Alimentar a vaca durante este período é um desafio, pois se trata de uma fase marcada por mudanças endócrinas, responsáveis pela preparação da fêmea para o crescimento final do feto, parto e lactogênese (Grummer, 1994).

Embora uma dieta bem balanceada possa reduzir os problemas no período de transição, este programa ficará comprometido caso haja diminuição de consumo, o que acarreta uma deficiência de energia e outros nutrientes. Neste contexto, a administração oral forçada de nutrientes pode ser uma ferramenta útil para aumentar os níveis de cálcio sangüíneos, minimizar a deficiência de energia, reidratar o animal e estimular a fermentação ruminal (Stokes \& Goff, 2001).

Pesquisas têm sido realizadas na busca de alternativas gliconeogênicas para diminuir a deficiência energética no período de transição, permitindo que os animais possam ter uma produção e reprodução condizente com o seu potencial. Neste sentido, tem sido avaliado o uso de gorduras vegetais e animais, propileno glicol, propionato de sódio, propionato de cálcio e ionóforos. 
Outra alternativa tem sido a utilização do "Dairy Power Drench ${ }^{\circledR}$ ", embora não se tenham dados de literatura sobre este produto.

Poucas pesquisas referentes a este assunto têm sido realizadas no Brasil, com exceção dos trabalhos de Castilho (1994), Magalhães (1995), Fonseca (1997) e Lago (1997), muito embora todos esses autores tenham trabalhado mais com cetose.

Portanto, o objetivo do presente trabalho foi avaliar as respostas orgânicas ao uso de substâncias neoglicogênicas na condição física, produção, reprodução e parâmetro sangüíneo, quando administradas diariamente por via oral em vacas leiteiras, desde duas semanas antes da data provável do parto até 7 semanas pós-parto (propionato de cálcio e propileno glicol) e 3 aplicações pós-parto, em dias consecutivos, iniciando-se no dia do parto (Dairy Power Drench $\left.{ }^{\circledR}\right)$. Os parâmetros avaliados foram: escore de condição corporal (ECC), peso dos animais, produção de leite, número de serviços por concepção, dias para ocorrência do $1^{\circ}$ cio detectável pós-parto, período de serviço e concentração plasmática de ácidos graxos livres (AGL). 


\section{REVISÃO DA LITERATURA}

\subsection{Desempenho reprodutivo}

A função reprodutiva envolve a interação de uma série de hormônios que desempenham papel fundamental, como reguladores de vários processos que culminam com a ovulação na fêmea e espermatogênese no macho. A função gonadal é controlada pelo eixo Hipotálamo-Hipófise, primeiramente pelas taxas de secreção das gonadotrofinas e pelos mecanismos de retroalimentação que, modulam de forma direta as funções específicas em determinados estados fisiológicos reprodutivos (Blache et al., 2001). Há, entretanto, uma série de hormônios ditos secundários à reprodução que, estão diretamente ligados aos processos metabólicos, certamente envolvidos nos processos produtivos das vacas leiteiras (Hafez, 1995).

Para Walker et al. (1996), a atividade reprodutiva de uma fêmea leiteira após o parto depende classicamente de três fatores: a) restabelecimento do ciclo ovariano normal; b) detecção de cio; c) correta técnica de inseminação artificial. Outros autores incluem também o balanço energético pós-parto (Macmillan et al., 1996), nutrição (Butler \& Smith, 1989), habilidade do inseminador (Senger et al., 1984) e produção de leite (Dhaliwal et al., 1996). Observação interessante foi feita por Britt (1994) afirmando que os efeitos do balanço energético negativo na reprodução de bovinos leiteiros não está apenas associado com o período em que ocorre a primeira ovulação, porém, com a viabilidade do oócito contido no folículo ovulatório e com a qualidade do corpo lúteo resultante da ovulação deste folículo. 
O tempo decorrido entre o parto até a retomada total da atividade úteroovariana é de extrema importância, pois indica que a fêmea está com o aparelho reprodutor morfofisiologicamente ativo e isto pode ajudar a manter uma melhor taxa de concepção, menor número de serviço por concepção e diminuir o intervalo entre partos.

Para que ocorra uma prenhez bem sucedida no pós-parto, são necessários alguns eventos: primeiramente uma secreção adequada de gonadotrofinas para iniciar um crescimento folicular, recrutamento, maturação, ovulação e formação de um corpo lúteo capaz de secretar níveis adequados de progesterona (Smith \& Wallace, 1998). Morrow et al. (1966) observaram que vacas que tiveram parto normal apresentaram a primeira ovulação 15 dias após o parto, enquanto as que tiveram algum tipo de problema no parto, a primeira ovulação aconteceu 34 dias após o parto.

$\mathrm{O}$ anestro pós-parto pode diminuir a eficiência reprodutiva por atrasar os dias para o primeiro serviço. Além disso, vacas que não ciclam nos primeiros 30 dias pós-parto exigem mais serviços por concepção, com maior risco de serem descartadas (Thacher \& Wilcox, 1973), talvez, relacionadas à menor ingestão de MS e maior perda de peso. Staples et al. (1990) verificaram que vacas que ovularam antes dos 22 dias pós-parto tiveram uma maior ingestão de MS, maior produção de leite e menor perda de peso do que aquelas que ovularam 42 dias após o parto. Lucy et al. (1992a) observaram que vacas com menor ingestão de matéria seca eram mais propensas a entrarem em anestro.

Dados de Thatcher \& Wilcox (1973) demonstraram que, vacas que apresentaram maior número de cios antes da inseminação aos 60 dias pósparto, tiveram uma maior taxa de não retorno $(47 \times 34 \%)$ e menos serviços por concepção $(2,21 \times 2,60 \%)$.

Segundo alguns autores, as vacas leiteiras iniciam sua atividade ovariana entre 15 e 49 dias pós-parto (Stevenson \& Britt, 1979; Lamming et al., 1982; Butler \& Smith, 1989) e a ovulação ocorre em 45 a 50\% das vacas dentro 
de 3 semanas após o parto, se a alimentação não for um fator limitante (Lucy et al., 1992a; Darwash et al., 1997).

Darwash et al. (1997), analisando os dados de 2503 lactações provenientes de 1682 vacas, demonstraram que a retomada da atividade luteínica precoce no pós-parto se associou positivamente com a fertilidade. Usando os mesmos dados, Lamming \& Darwash (1998) observaram 28,7 dias de intervalo médio do parto até a primeira elevação de progesterona. Levandose em consideração que a progesterona é o principal esteróide secretado pelo corpo lúteo (Wettemann, 1980) e, portanto, é um dos melhores indicadores de início da atividade ovariana cíclica pós-parto. Há, entretanto, autores que consideraram que $11 \%$ dos animais que apresentaram progesterona elevada era devido a luteinização de folículos e os $89 \%$ restantes à presença de um corpo lúteo endocrinamente funcional (Manns,1983).

Garverick \& Smith (1993) apontam que a maximização da eficiência reprodutiva é um dos principais fatores para o sucesso econômico da bovinocultura leiteira e de corte e o desenvolvimento de novos métodos, para incrementar o desempenho reprodutivo, depende da compreensão dos mecanismos neuroendócrinos, que controlam o processo, incluindo a retomada da atividade cíclica após o parto e o restabelecimento do ciclo estral, ovulação e gestação a termo.

Durante o ciclo estral normal, os bovinos apresentam padrões de crescimento foliculares em forma de ondas, as quais acontecem a cada 10 dias (variação de 6-10 dias), observando-se duas ou três ondas foliculares (Wiltbank, 1998). Os requisitos para o crescimento folicular envolvem interações de hormônios hipotalâmicos $(\mathrm{GnRH})$, hipofisários (FSH, LH e BST), pancreáticos (insulina) e hepáticos (IGF-1) que interagem de forma sincrônica, culminando com a ovulação, formação de um corpo lúteo funcional cíclico ou gestacional. 
Segundo Ferguson (1995), um dos aspectos fundamentais para o êxito de qualquer empreendimento em gado leiteiro é a obtenção de índices reprodutivos viáveis e é avaliada pelo monitoramento de índices como:

1) Idade e peso ao primeiro parto: $24 \mathrm{meses},>600 \mathrm{~kg}$, para raças pesadas;

2) Intervalo entre partos: $>80 \%$ das vacas inseminadas com intervalos entre partos de 11 a 13 meses;

3) Taxa de descarte por ano: $>80 \%$ das vacas inseminadas tornam-se gestantes, 25 a $40 \%$ das vacas parindo são descartadas do rebanho por ano e menos de $30 \%$ são devidos a problemas reprodutivos;

4) Perda de prenhez: abortos e mortalidade peri-natal, menos $15 \%$ das vacas gestantes.

\subsubsection{Involução uterina}

A condição do útero no pós-parto constitui um dos principais fatores que influenciam a fertilidade das vacas e a rentabilidade do empreendimento.

O puerpério na vaca é definido como sendo o período que vai do parto até o primeiro cio pós-parto, no qual uma nova gestação pode ser estabelecida (Malven, 1984). É um processo fisiológico complexo que envolve: a) recuperação do útero da gestação anterior, caracterizada por redução do seu tamanho, perda de tecido residual e regeneração endometrial (Schirar \& Martinet, 1982; Arthur et al., 1990); b) retorno da atividade cíclica ovariana com o restabelecimento do eixo hipotálamo-hipófise-ovário-útero (Malven, 1984; Peters \& Laming, 1984; Saturnino, 1989), o qual pode ainda segundo, Olson et al. (1986), ser subdivido em puerperal, intermediário e pós-ovulatório. O período puerperal foi definido como o intervalo do parto até a hipófise tornar-se responsiva ao $\mathrm{GnRH}$ (7 a 14 dias pós-parto), o intermediário vai desde o final do período puerperal até a primeira ovulação pós-parto e o período pósovulatório é o intervalo entre a primeira ovulação e involução uterina total. Esta ocorre, segundo Lewis et al. (1984), quando os cornos e o colo medem 
aproximadamente $40 \mathrm{~mm}$ de diâmetro e as carúnculas estão totalmente epitelizadas.

Os mecanismos de defesa uterina contra os microrganismos contaminantes são mantidos de 3 diferentes modos: anatômicos, pelo tipo de epitélio encontrado no endométrio, quimicamente pela secreção de muco das glândulas endometriais e, imunologicamente através da ação das células polimorfonucleares e anticorpos humorais (Dhaliwal et al., 2001). A quebra destes mecanismos permite a ação dos microrganismos patogênicos oportunistas, sendo a maioria encontrado na região posterior do trato gastrointestinal e perineal (Paisley et al., 1986; Hussain et al., 1990), para colonizar o endométrio e causar endometrite (Vandeplassche \& Bouters, 1976).

As inflamações do endométrio podem ocorrer após o coito, inseminação artificial ou mais comumente após o parto (Dhaliwal et al., 2001). Na maioria dos bovinos, no período de 1 a 4 semanas após o parto, os microrganismos contaminam o lúmen uterino e ocorre uma cura espontânea dentro de 6 semanas pós-parto (Griffin et al., 1974). As vacas incapazes de eliminar os agentes infecciosos, podem desenvolver endometrites subseqüentemente (Ball et al., 1984).

A partir da década de 1970, os critérios utilizados pelos diversos autores para avaliar a involução uterina, com o auxilio da palpação retal, estão alicerçados, basicamente, na verificação do tempo em que o útero retorna a posição normal na cavidade pélvica, a recuperação do tamanho e da simetria dos cornos uterinos e do restabelecimento da consistência e do tônus miometrial pós-parto ou puerpério (Gonzales-Sanches et. al., 1999). Com esta metodologia, Marion et al. (1968) e Vasconcelos et al. (1993) estudaram o diâmetro do útero como indicador da involução do aparelho reprodutivo e sua conseqüente volta à normalidade, tendo os últimos autores verificaram que a taxa de involução uterina pós-parto era rápida e uniforme até o $30^{\circ}$ dia após o parto, com as modificações do diâmetro mais acentuadas e detectáveis do que as que ocorriam no colo. Há, entretanto, divergência nos dados de pesquisas, 
no que diz respeito ao tempo necessário para involução uterina, mesmo entre animais da mesma raça ou de raças diferentes (Gonzales-Sanches et. al., 1999).

Para que ocorra um processo reprodutivo ideal é necessário que haja uma completa e total involução uterina, a qual deve acontecer físicohistologicamente aproximadamente aos 40 dias pós-parto (Schirar e Martinet, 1982; Kamimura et al., 1993). Da mesma forma, Mcentee (1990) aponta que o restabelecimento da prenhez envolve uma série de processos simultâneos: redução do tamanho do órgão, perda de tecido, reposição tecidual e diminuição do fluído tissular e de tecido muscular do colo. O mesmo autor destaca também que o útero diminui rapidamente de tamanho após o parto e pode ser palpado via retal completamente 7 a 10 dias, com grandes modificações ocorrendo até o vigésimo dia, retornando ao seu tamanho normal, não gravídico, aproximadamente 45 dias após o parto. Outros autores encontraram 26 a 30 dias em animais mestiços (Araújo et al., 1974; Lara, 1986) e 24 a 32 dias em raças zebuínas (Rao \& Rao, 1980; Eduvie, 1985; Nogueira et al., 1993). Em raças Européias, segundo Garcia \& Larsson (1982), 85\% dos animais completaram a involução uterina até o $42^{\circ}$ dia pós-parto. Por outro lado, Roberts (1986) determinou que a involução uterina ocorreu entre 50-60 dias pós-parto. Este intervalo é extremamente variável e pode ocorrer entre 15 e 100 dias (Marques, 1993), na dependência da retomada dos ciclos ovarianos.

O processo de involução é regulado pelas contrações miometriais e consiste de descarga de lóquio, eliminação dos microrganismos contaminantes e regeneração do endométrio. Bactérias patogênicas e não patogênicas podem entrar no útero no momento do parto e multiplicar-se rapidamente. Entretanto, em condições normais, o útero possui mecanismos de defesa para combater esta invasão bacteriana (Hafez, 1995), em função de que cada ciclo estral é acompanhado de secreção de estrógeno e logo após, de progesterona. O estrógeno estimula o fluxo sangüíneo para o útero, as miocontrações uterinas e inicia uma leucocitose fisiológica, a qual facilita a remoção do "debris" oriundos 
do parto anterior (Foote \& Riek, 1999). Fatores como produção de leite, condição corporal, estação do ano e nutrição influenciam a duração deste período (Peters \& Laming, 1984), porém, o número de partos é considerado por alguns autores, o fator de maior influência no processo da involução uterina (Morrow et al., 1969; Vasconcelos et al., 1993).

Um ponto fundamental durante o puerpério é a perfeita sincronia dos processos fisiológicos, favorecendo os mecanismos intrínsicos de defesa uterina contra qualquer tipo de agressão.

Uma nova gestação só é possível com uma perfeita interação entre o processo de recuperação uterina e o restabelecimento da função cíclica ovariana, tendo como resultado a funcionalidade do sistema genital como um todo. Há, ainda, interação com fatores de origem genética, nutricionais, sanitários e de manejo, atuando tanto no pré como no pós-parto (Ayalon, 1984), com reflexo negativo na eficiência reprodutiva (Morrow et al., 1969).

O restabelecimento precoce do ciclo ovulatório no pós-parto é importante, porque determina um maior número de ciclos estrais para se obter uma nova prenhez com um menor número de serviço (Nebel \& Mcgilliard, 1993), fator chave para se obter altas taxas de reprodução (Butler \& Smith, 1989).

\subsubsection{Período de serviço}

O período de serviço é considerado o número de dias entre o parto e a primeira inseminação/serviço que resulte em gestação e está na dependência de: período de espera voluntária; taxa de detecção de estro (TDE); e a taxa de concepção (TC) (De Kruif, 1978). Juntos, estes índices formam a taxa de prenhez (TP) (TP=TDE X TC), que representa a proporção de vacas que ficam gestantes no período de um ciclo estral (21dias). A taxa de prenhez determina a 
velocidade com que as vacas ficam gestantes a partir do período de espera voluntário (Ferguson, 1995).

Falhas na deteç̧ão do estro e/ou na taxa de concepção diminuem a taxa de prenhez aumentando o período de serviço médio do rebanho e conseqüentemente diminuindo a eficiência reprodutiva.

Com o aumento dos níveis de produção de leite nos E.U.A (2-3\% anual), tem-se observado uma diminuição na taxa de concepção da ordem de 60, 50, $40 \%$ em 1955, 1975, 1995, respectivamente; sendo o decréscimo maior nas vacas de alta produção, porém, mantidas em torno de $65 \%$ nas novilhas (Fricke, 1999). Comportamento similar foi observado em análise feita em rebanhos leiteiros do Reino Unido, nos quais observou-se um decréscimo de $7 \%$, na taxa de prenhez nos últimos 20 anos ficando em 46\% (Esslemont \& Kossaibati, 1998).

Desde a década de 70 , vários pesquisadores têm observado que, o baixo consumo de energia prejudica a função reprodutiva em vacas leiteiras (Lamond, 1970; Spalding, 1975; Olds et al., 1979), tendo sido relatado um aumento no período de serviço em vacas leiteiras deficientes em energia (Stevenson \& Britt, 1979; Andersson, 1988; Butler \& Smith, 1989; Staples et al., 1990). O ponto máximo de deficiência energética ocorre durante as duas primeiras semanas de lactação (Butler et al., 1981; Grummer, 1995), e a primeira ovulação geralmente ocorre aproximadamente 10 dias após o "nadir" do balanço energético (Butler et al., 1981; Butler \& Smith, 1989). A ovulação do folículo dominante durante o início da lactação é dependente do completo restabelecimento da secreção pulsátil de $\mathrm{LH}$, conduzindo ao crescimento préovulatório e produção de estrógeno (Butler, 2000).

Oltenacu et al. (1980) mostraram através de modelos matemáticos, haver um aumento na produção de leite anual com a diminuição do peíodo de serviço (PS). Este índice que é variável segundo os autores, sendo de 30 a 60 dias, valores ótimos (Dijkhuizen et al., 1985; Holmann et al., 1984). Altas produções durante o início da lactação se relacionam com aumento do PS, 
talvez devido a um antagonismo biológico entre balanço de energia e ciclos reprodutivos.

Alguns sistemas de manejo adotam atrasar as inseminações das vacas de alta produção porque: 1) se obtém maiores produções; 2) existe a idéia de que vacas com maior produção produzem mais leite por dia de vida útil na propriedade, em função das lactações mais longas e 3) economia no uso do sêmen quando se atrasa a inseminação para ser realizada após o período de balanço energético negativo (BEN) (Lee et al., 1997).

Os estudos de Berger et al. (1981) indicaram que vacas com maior produção de leite durante o início da lactação e vacas com maior mérito genético para produção de leite também tiveram maior período de serviço que as vacas com produção média durante o início da lactação. Para Erb et al. (1952), um maior período de serviço suporta elevadas produções na referida lactação, devido ao atraso na concepção reduzir a competição por nutrientes no desenvolvimento do feto durante a lactação de 305 dias. Outros fatores envolvidos na fertilidade incluem doenças e produção de leite que, embora numerosos, não têm produzido conclusões consistentes.

Loeffler et al. (1999) e Darwash et al. (1997) analisaram dados de produção e sua relação com parâmetros de fertilidade, em 1737 lactações de uma única fazenda durante 7 anos. Seguindo a mesma metodologia, Bagnato \& Oltenacu (1984) examinaram dados de 1,2 milhões de lactações de 305 dias em equivalente adulto de 12 anos e notaram que as vacas de alta produção tiveram uma taxa de 0,15 menor ao $1^{\circ}$ serviço/concepção e 0,32 mais serviços/concepção que as vacas de baixa produção nas mesmas propriedades.

A herdabilidade estimada para períodos de serviços (PS) e intervalo entre partos tem sido baixa, geralmente menor que 8\% (Schaffer et al., 1972; Berger et al., 1981; Hansen et al., 1983 e Funk et al., 1987).

Segundo Nebel \& Mcgilliard (1993), o PS deve ser o objetivo a perseguir na propriedade, bem como a determinação do período de espera voluntário, 
porém PS e IEP (Intervalo Entre Parto) são medidas insatisfatórias de desempenho reprodutivo para se determinar a potencial relação entre produção de leite e reprodução. Estes autores observaram que mesmo havendo aumento na produção de leite, o número de inseminações por prenhez não diferiu e os rebanhos mais produtivos tiveram 21 dias abertos (1ciclo estral) a menos que as propriedades com menor produção, sugerindo ter havido melhor detecção do cio nestes rebanhos. Barr (1975) e Slama et al. (1976) afirmaram que cios não observados foram responsáveis pelo aumento de duas vezes no PS, e concluíram que $\mathrm{o}$ antagonismo entre produção de leite e desempenho reprodutivo pode ser compensado por um melhor manejo, principalmente na área de detecção de cio. Entretanto, Laben et al. (1982) e Wiggans et al. (1987) constataram aumento dos dias decorridos para o primeiro serviço, menor taxa de detecção de cio, concepção ao primeiro serviço e aumento dos dias abertos nas propriedades com maiores produções.

Roche et al. (2000) afirmaram que uma alta eficiência reprodutiva em rebanhos requer: 1- um período de transição livre de doenças, 2- uma alta taxa de animais sendo iseminados e 3- uma alta taxa de prenhez por inseminção ou cobrição. As taxas de concepção podem ser influenciadas por diversos fatores, que podem ser agrupados como iatrogênicas, inerentes ao touro/sêmen, a vaca, ao ambiente e genéticos, os quais podem comprometer não apenas a taxa de concepção, bem como a manutenção da prenhez (Klingborg, 1987 e Hardin, 1993). Fatores inerentes ao ambiente e manejo, incluindo estresse térmico, desbalanço nutricional, de toda ordem, podem comprometer a taxa de prenhez do rebanho (Fergusson \& Chalupa, 1989; Son et al., 1996). 


\subsubsection{Balanço energético}

Após o parto, a taxa de aumento na produção de leite excede à de ingestão de alimento, gerando uma diferença entre a dieta energética exigida para mantença e produção de leite e a ingerida. $O$ resultado é um balanço energético negativo (BEN), de intensidade e duração variáveis entre os animais. Estas diferenças são importantes, devido a sua associação com a produção e fertilidade (Butler et al., 1981; Butler \& Smith, 1989; Canfield \& Butler, 1990; Canfield et al., 1990; Senatore et al., 1996; De Vries et al.,1998; Villa-Godoy et al., 1988; Beam \& Butler, 1998).

Existem algumas evidências que a fertilidade é inibida através do mecanismo de balanço negativo de energia (Richards et al., 1986; Butler \& Smith, 1989; Spicer et al., 1990; Zurek et al., 1995 e Senatore et al., 1996). O balanço negativo de energia pode ser claramente descrito quando pouca energia é consumida em comparação com as necessidades.

Desta mesma maneira, a vaca mobiliza gordura corporal pós-parto para obter energia aumentando a concentração de ácidos graxos livres (AGL) circulantes, que podem provocar a esteatose hepática, diminuindo a resposta ao BST, acarretando menores níveis circulantes de IGF-1, havendo tendência a se normalizar após as vacas recuperarem o seu balanço energético (Lucy et al., 2001). O IGF-1 no sangue atua de forma sinérgica com as gonadotrofinas (LH e FSH) para estimular o crescimento folícular. Os peptídeos (IGF-1 e IGF-2) exercem muitas ações dentro do ovário bovino, afetam a proliferação das células da granulosa, atividade aromatase e a biosíntese de progesterona em cultura de ovários bovinos (Spicer et al., 1991). Assim as gonadotrofinas naturalmente encontradas no sangue se tornam mais potentes nas vacas tratadas com BST, o que provoca um maior recrutamento de folículos (Lucy, 2001). Spicer et al. (1990) observaram que a recuperação do balanço energético esteve associado com o nível sérico de IGF-1 durante o início da lactação e, com um aumento da secreção de progesterona no primeiro e 
segundo cio pós-parto, e que, o aumento da produção se relacionou negativamente com a diminuição sérica de IGF-1 e balanço energético. Isto pode explicar em parte a atividade ovariana reduzida, observada na presença de balanço energético negativo. Spicer et al. (1990) também sugeriram que os efeitos do balanço negativo de energia sobre a fertilidade são mediados através de certos hormônios tais como insulina, fatores de crescimento semelhantes a insulina (IGF-1) e somatotrofina bovina.

Ferguson (1994) afirmou que a extensão do balanço negativo de energia influencia a duração dos problemas de fertilidade. Na maioria dos estudos foi observado que o BEN é altamente correlacionado com a produção de leite ou condição corporal (Holter et al., 1990; Nebel \& McGilliard, 1993; Veerkamp \& Brotherstone, 1997 e Heuer et al., 1999). Um terceiro indicador do desbalanço energético é a diminuição na gordura do leite ou a relação gordura/proteína do leite (Heuer et al., 1999). O BEN pode também afetar indiretamente a fertilidade devido ao aumento da incidência de doenças que tem sido associadas com vacas altas produtoras (Bigras-Poulin et al., 1990 e Heuer et al., 1999) e o aumento da severidade da doença tem sido relacionado com o estado cetótico.

Os mecanismos pelos quais o BEN influencia a primeira ovulação pósparto não estão bem identificados, mas podem incluir a insulina, a glicose, os ácidos graxos livres e/ou IGF-1 (Butler \& Canfield, 1989 e Britt, 1994).

\subsubsection{Animais de alta produção de leite}

Segundo Herdt (1988), o final da gestação e início da lactação representam uma fase de demanda metabólica crítica para a vaca leiteira, pois além da exigência em energia, há necessidade de enormes quantidades de glicose para sustentar a síntese de lactose pela glândula mamária. As vacas de alta produção podem exigir, para esta finalidade até $80 \%$ do suprimento total de glicose. 
A produção de leite de uma vaca especializada, segue uma função curvilínea previsível, que atinge um pico entre a sexta a nona semana de lactação e então diminui a uma taxa constante. O acúmulo dos rendimentos e a entrada econômica total dentro de uma lactação é determinada pelo pico e persistência da produção de leite (Nebel \& McGilliard, 1993).

Segundo Butler \& Smith (1989) e Britt (1992), o pico de produção de leite ocorre de 5 a 8 semanas pós-parto e acontece antes da ingestão máxima do consumo de energia, causando um BEN, podendo resultar em anestro pósparto prolongado, baixa produção de progesterona luteínica e baixa taxa de concepção.

Vacas de alta produção apresentam concentrações elevadas de somatotrofinas e diminuídas de insulina (Bonczek et al., 1988) e altos níveis sangüíneos de hormônios lactogênicos. Estas alterações afetam, de algum modo, a atividade ovariana e o desequilíbrio energético no período de transição (Spicer et al., 1990; Nebel \& McGillard, 1993; Spicer et al., 1993).

A somatotrofina bovina é um hormônio da hipófise anterior, encontrado na forma natural em bovinos, que após ser liberada é capaz de atuar em todos os tecidos, já que existem receptores em todo o organismo (Lucy et al., 1998). Entretanto, o local com maior quantidade de receptores é o fígado, órgão no qual este hormônio causa aumento da secreção do IGF-1 (Etherton \& Bauman, 1998). No início da lactação, foram observados altos níveis de BST e baixos de IGF-1; estas associações foram relacionadas com queda de desempenho reprodutivo, maior dificuldade no manejo reprodutivo destes animais, como por exemplo, a manutenção da taxa de concepção. O reflexo negativo sobre a taxa de concepção foi da ordem de $15 \%$, segundo Butler \& Smith (1989). Os efeitos do aumento de produção de leite, sobre o desempenho reprodutivo, estão associados basicamente com dois fatores: alterações nos perfis hormonais e metabólicos, assim como aumento no déficit energético no início de lactação, os quais estão intimamente relacionados (Santos, 1996). 
Berger et al. (1981) encontraram correlação genética positiva entre produção de leite corrigida aos 60 dias e PS e números de serviços por concepção em animais de primeira e segunda lactação; e concluíram que, o aumento de pressão de seleção de animais jovens para altas produções de leite leva os animais a uma queda na eficiência reprodutiva.

Vários parâmetros reprodutivos têm sido avaliados e comunicados através de pesquisas, entre produção de leite e desempenho reprodutivo, dentre eles o período de serviço e o intervalo entre parto. Embora, o período de serviço e, intervalo entre parto sejam medidas insatisfatórias para determinar possíveis relações de produção de leite e reprodução. Talvez, a taxa de concepção ou número de serviços por concepção estejam mais associados, haja visto que, vacas produzindo mais leite geralmente possuem menor taxa de concepção (Laben ,1982; Fonseca et al.,1983; Stevenson et al., 1983; Faust et al., 1988). Entretanto, dados de pesquisas indicam haver uma relação antagônica entre alta produção de leite e desempenho reprodutivo, pouco é conhecido sobre o desempenho reprodutivo de propriedades leiteiras nas quais as lactações excedem $13.500 \mathrm{~kg}$ (Nebel \& McGilliard, 1993).

Os parâmetros de eficiência reprodutiva são de baixa herdabilidade, razão pela qual os fatores ambientais são de importância fundamental (Santos, 1996). Nos bovinos, a concepção e manutenção da gestação são altamente influenciadas por qualquer fator que possa alterar o equilíbrio metabólico e endócrino. Levando-se em consideração que, dentre os fatores ambientais, a nutrição é a variável de maior impacto que afeta a reprodução, fica fácil entender porque deficiências, excesso e ou mesmo desequilíbrios de nutrientes, refletem no desempenho reprodutivo em novilhas e vacas de corte e leiteiras (Santos \& Santos, 1998).

No pico da lactação, as vacas de alta produção apresentam menor duração do período de cio, menores taxas de concepção, maiores perdas de prenhez, maior número de animais em anestro, bem como maior incidências de gestações gemelares (Wiltbank, 2002). Algumas evidências indicam que estes 
animais de alta produção, até antes dos 150 dias de lactação, têm ciclos ovarianos normais, porém, não manisfestam a aceitação da monta, característica típica de vacas em cio (Harrison et al., 1989).

Altas produções de leite têm sido associadas com longos períodos para retomada da atividade ovariana pós-parto (Beam \& Butler, 1998; Nebel \& McGillard, 1993). Por outro lado, outros pesquisadores não têm concordado com estas afirmativas (Villa-Godoy, 1988; Harrison, 1990), ou mesmo afirmam o inverso (Staples et al., 1990; Lucy et al., 1992a).

Harrison et al. (1990) verificaram haver alta correlação entre produção elevada de leite e ingestão de matéria seca e, maior propensão a apresentar anestro. Outra observação feita em vacas leiteiras de alta produção é a relação do BEN com a diminuição na taxa de concepção (Britt, 1992 e Sklan et al., 1994).

Segundo Vasconcelos et al. (1998), vacas leiteiras sob mesmo "status" energético, porém ingerindo maiores quantidades de MS, possuem menores concentrações de progesterona plasmáticas. O maior consumo de MS aumenta o fluxo sangüíneo hepático, com possível aumento da taxa de metabolização ("clearance") do esteróide, o que pode afetar o desenvolvimento folicular, a maturação do oócito e conseqüente comprometimento da fertilidade. Observações semelhantes foram feitas por Ferrel (1991) citado por Santos (1996), onde, o maior consumo de matéria seca também aumenta o volume e o afluxo sangüíneo hepático. Além disso, há indícios de que a maior ingestão de alimentos aumente a concentração de enzimas hepáticas que oxidam hormônios esteróides, o que resultaria em um reduzido "feedback" negativo a secreção de LH e FSH. Cummining et al. (1971) foram os primeiros a reportar a relação entre consumo de matéria seca e nível de progesterona plasmática. A maioria das pesquisas direcionadas para as concentrações de progesterona tem sugerido que vacas com BEN e níveis baixos de progesterona, reflete muita das vezes uma disfunção do corpo lúteo (Carstairs et al., 1980; Ducker et al., 
1985 e Villa-Godoy et al., 1988), estes animais podem ter um maior risco de luteólise precoce (Rabiee et al., 2001).

A função reprodutiva pós-parto em vacas leiteiras, entre outros fatores, é diretamente dependente da disponibilidade de alimentos energéticos, para produção de leite e mantença. A energia é o nutriente mais importante que afeta a reprodução dos bovinos. O consumo deficiente de energia está correlacionado com baixo desempenho reprodutivo, dias para primeiro estro e ovulação pós-parto aumentados e taxa de concepção diminuída.

A maior demanda metabólica provocada pela alta produção de leite e a baixa ingestão de matéria seca resulta em BEN, o qual afeta o momento de reinício de ciclos estrais ovulatórios (Butler \& Canfield, 1989); e dependendo da extensão e profundidade do balanço energético, pode determinar o intervalo entre o parto e a primeira ovulação (Butler et al., 1981), tendo estes autores observado que a ovulação ocorreu aproximadamente 10 dias após o nível mais baixo do balanço mais negativo (NADIR).

A procura de maior eficiência deve ser uma constante, pois se diz que: "só os eficientes sobreviverão". Na criação animal, isto não é diferente, pois todos, técnicos e produtores, devem buscar melhores índices zootécnicos como: menor idade a primeira cobertura, ao abate, melhor conversão alimentar, menor mortalidade, menor incidência de mastite, menor incidência de distúrbios metabólicos, maior produção de leite e melhor eficiência reprodutiva. O conhecimento, avaliação e interpretação dos dados da eficiência reprodutiva é fundamental, visto que estes índices determinam o nascimento de animais para reposição, evolução do rebanho, uma nova lactação e as entradas financeiras com venda de leite e animais.

Hardin (1993) afirma que o sucesso no desempenho reprodutivo de rebanhos leiteiros depende de um manejo eficiente, de coleta e processamento de dados do rebanho, especialmente daqueles associados com a retomada da atividade cíclica no pós-parto. A acurácia na detecção dos cios e taxas de concepção são fundamentais para o estabelecimento de desempenho 
reprodutivo satisfatório. De Kruif (1993) destaca que a fertilidade de um rebanho deve ser avaliada baseando-se em três critérios: a) taxa de prenhez após a primeira inseminação artificial; b) número de serviço/prenhez e c) intervalo parto/concepção.

No início da lactação, vacas de alta produção apresentam balanço energético negativo, e sua magnitude, influencia o desenvolvimento folicular e o intervalo para a primeira ovulação (Staples et al., 1990). Conforme já mencionado anteriormente, os mecanismos pelos quais o BEN influencia a primeira ovulação pós-parto não estão bem identificados, porém, podem envolver a insulina, a glicose, os ácidos graxos livres e/ou IGF-1 (Butler \& Canfield, 1989 e Britt, 1994). Além destas características, as vacas de alta produção apresentam concentrações elevadas de somatotrofinas e diminuídas de insulina (Bonczek et al., 1988).

A severidade e a duração do balanço energético negativo, durante 3 a 4 semanas pós-parto, estão altamente correlacionadas com o dia em que ocorre a primeira ovulação. Há também, uma correlação positiva entre o período em que acontece a primeira ovulação e a taxa de concepção dos próximos cios; razão pela qual o período do parto até a primeira ovulação representa uma importante interação entre o "status" energético e desempenho reprodutivo (Butler, 2000).

As vacas respondem de forma individual ao balanço energético negativo e, através de diferentes combinações de consumo de alimento, mobilização de tecido adiposo e menor produção de leite (Garnsworth, 1988; Butler \& Smith, 1989 e Nebel \& Mcgilliard, 1993). Ao aproximar-se o parto, a mobilização das reservas corporais tem objetivo principal de atender, parte das necessidades em energia e proteínas (Bertics et al., 1992).

O alto grau de lipólise, observado neste período, é fator principal de risco, associado a períodos anovulatórios prolongados (Roche et al., 2000). Entretanto, não está confirmado se é somente a mobilização de gordura que pode afetar o tempo da primeira ovulação pós-parto. Uma razão para esta 
incerteza é o pouco conhecimento sobre o mecanismo fisiológico que conecta a atividade do tecido adiposo ao eixo reprodutivo (Kadokawa et al., 2000).

Recentemente, dados de pesquisas têm proposto o envolvimento da leptina no consumo de alimentos, como sinalizador no sistema nervoso central, mais especificamente ao local que controla a liberação do LH (Cunninghan et al., 1999 e Blache et al., 2000a). O restabelecimento do padrão pulsátil de LH é o fator responsável pelo desenvolvimento folicular e início da atividade cíclica ovariana pós-parto. Em bovinos de corte, a amamentação e subnutrição são os fatores que mais influenciam este padrão pulsátil.

Segundo Ferreira (1995), a vaca leiteira apresentando BEN no início da lactação, compara-se a uma condição de subnutrição. O BEN atrasa a atividade ovariana luteal cíclica pós-parto de duas maneiras: a) interfere com a habilidade do eixo hipótalamo-hipofisário, impedindo-o de desenvolver o necessário padrão pulsátil de $\mathrm{LH}$, b) limita a resposta do ovário ao estimulo gonadotrófico em função da deficiência energética e dos baixos níveis de insulina, observado no início da lactação (Butler \& Canfield, 1989).

O intervalo entre o parto e o início da recuperação do balanço energético é positivamente correlacionado com o número de dias do parto até a primeira ovulação (Butler et al., 1981 e Zurek et al., 1995). Normalmente, espera-se que aos 50 dias pós-parto, menos que $15 \%$ das vacas estejam em anestro, e isto pode estar na dependência da magnitude da perda de peso (Rice, 1991), quanto antes as fêmeas reiniciarem suas atividades ovarianas menor será o período de serviço. Em termos hormonais, Harrison et al. (1990) e Senatore et al. (1996), consideraram que a ovulação tenha ocorrido quando se observa uma elevação da progesterona para $1 \mathrm{ng} / \mathrm{mL}$. Entretanto, outros autores consideram que este hormônio deve manter-se elevado por um determinado número de dias (Spicer et al., 1990; Lucy et al., 1992a e Zurek et al., 1995). 


\subsection{Condição corporal e reprodução}

A produção de leite no início da lactação se dá, essencialmente, às custas de reservas corporais acumuladas no pré-parto. A mobilização de gordura corporal que ocorre neste período fornece energia para atender a produção de leite parcialmente (Boyd et al., 1987 e Garnsworthy \& Jones, 1987). A quantidade máxima de leite que pode ser sintetizada a partir das reservas corporais pode ser considerada até $30 \%$ durante o primeiro mês, $20 \%$ no segundo e $10 \%$ no terceiro mês de lactação, respectivamente. Essa quantidade produzida dependerá do estado físico do animal no momento do parto, estimando-se que possa produzir até 900, 600 e 300 litros se o animal parir em bom, regular e mau estado corporal, respectivamente (Soberanes, 1989). Portanto, o manejo nutricional no período pré-parto deve ter como objetivo a recuperação das reservas energéticas utilizadas na lactação anterior, sabendo-se que este é um período de menor exigência nutricional e maior eficiência por parte do animal em transformar em peso o alimento consumido.

O escore de condição corporal (ECC) tem-se tornado uma ferramenta padrão de manejo nutricional usado pelos profissionais da área de bovinocultura, para quantificar as reservas de energia das vacas durante os períodos estratégicos do ciclo lactacional. É um método subjetivo de avaliar as reservas energéticas das vacas, baseado na observação visual e palpação de áreas específicas de tecido adiposo subcutâneo, na forma de triglicerídeos contendo ácidos graxos de cadeia longa. A avaliação do escore de condição corporal de vacas leiteiras e corte tem sido recomendada, na prática, como um meio de se avaliar o grau relativo do balanço negativo de energia (Wrigth et al., 1984).

As reservas energéticas lipídicas corporais tem localizações, principalmente no tecido subcutâneo, muscular e abdominal; a maior parte (50 $70 \%$ ) se encontra nos tecidos subcutâneos e musculares. A gordura intraabdominal corresponde a aproximadamente 23 a $30 \%$ do total (Wildman et al., 
1982). Baseados nestas observações, os autores estabeleceram uma escala de condição corporal que varia de 1 a 5 (sendo 1 os animais magros e 5 os animais obesos), onde cada unidade de condição corporal equivale, em vacas holandesas, a aproximadamente $84 \mathrm{~kg}$ de peso vivo (NRC, 2001).

Para Weaver (1991), o manejo no pré-parto deve ter como objetivo recuperar peso, proporcionando condições para que as vacas cheguem ao parto com uma condição corporal de 3,25 a 3,5, na escala de 1 a 5 , não devendo perder mais que 0,5 ponto no escore após o parto. Segundo Ruege et al. (1992), nos primeiros 60 dias de lactação podem ocorrer perdas de escore corporal, não devendo ultrapassar a uma unidade; ou equivalente, numa vaca de $650 \mathrm{~kg}$ a $417 \mathrm{Mcal}$ de $E L_{L}$ (energia líquida para lactação), energia suficiente para produzir $564 \mathrm{~kg}$ de leite, corrigido para $4 \%$ de gordura. Neste mesmo trabalho, os autores observaram um aumento no período de serviço, quando a perda do escore foi acima de 0,75 pontos. A mudança no ECC nas primeiras semanas pós-parto pode ser mais importante que a própria condição corporal ao parto, que são reflexos de mudanças no BEN. As vacas que perderam mais que 0,75 unidades na ECC durante os primeiros 30 a 40 dias pós-parto tiveram sua função ovariana comprometida e aumento nos dias para concepção (Ferguson, 1991).

Estudos anteriores mostraram que o escore de condição corporal ao parto e a perda da condição corporal no início da lactação foram relacionados com a saúde animal (Reid et al., 1986; Gearhart et al., 1990 e Markusfeld et al., 1997), fertilidade (Markusfeld et al., 1997; Garnsworthy, 1988 e Gearhart et al., 1990) e produção de leite (Pedron et al., 1993 e Markusfeld et al., 1997).

Segundo o NRC (2001), o ECC está correlacionado com gordura e o conteúdo de energia. Em bovinos leiteiros, o excesso de condição corporal $(>4,0)$, ao parto, pode influenciar a ingestão de MS e o BEN durante o final da gestação e início da lactação (Santos, 1996).

Muito pouco é conhecido sobre a associação entre dados da condição corporal, saúde, reprodução e produção de leite (Heuer et al., 1999). Desta 
forma, ao selecionar vacas para alta produção, se estará selecionando, indiretamente, animais que fisiologicamente utilizarão mais reservas corporais para produzir. Esta afirmativa se baseia no fato de que as vacas leiteiras no período de transição sofrem uma diminuição na ingestão de MS, o que as obriga a produzir às custas das suas reservas corporais.

Entretanto, este fato é muito importante, pois Mertens (1986) afirma que o CMS é a variável mais importante que afeta o desempenho animal e é regulado por mecanismos de curto e longo prazo. Neste período, podem ser perdidas até $60 \%$ do total das gorduras corporais (Tamminga et al., 1997). Roseler (1997) considera que $45 \%$ da variabilidade do consumo de matéria seca é devido a produção de leite, $25 \%$ é devido aos alimentos e manejo, $17 \%$ ao peso vivo, $10 \%$ ao clima e $6 \%$ é devido à condição corporal. A produção de leite no início da lactação se dá, em parte, às custas de reservas corporais acumuladas no pré-parto (Boyd et al., 1987; Garnsworthy \& Jones, 1987).

As mudanças no peso corporal das vacas, nem sempre, refletem as mudanças verdadeiras no depósito de tecido gorduroso. Neste particular, experimentos onde o depósito de tecido gorduroso foi avaliado ao abate, observou-se uma variação de no máximo de $40 \%$ das reservas energéticas, enquanto pouca ou nenhuma mudança foi encontrada no peso corporal do parto até 5 a 12 semanas após (Andrew et al., 1994; Gibb et al., 1992).

Vacas de alta produção, normalmente não ingerem quantidades adequadas de nutrientes para suportar altas produções no início da lactação, com conseqüente perda de peso, alterando a sua condição corporal, o que pode alterar $o$ intervalo entre $o$ parto e primeiro cio e consequentemente a eficiência reprodutiva pós-parto (Miyoshi et al., 2001).

Butler et al. (1981), Fulkerson (1984) e Santos (1996) concluíram que a boa condição corporal ao parto foi um fator importante para a retomada da atividade cíclica pós-parto, tendo-se observado que as vacas que pariram em bom estado corporal apresentaram cio mais cedo, quando comparadas com 
aquelas vacas que pariram com baixa condição corporal, independente da variação do peso vivo.

De acordo com Rice (1991), as perdas severas de peso (20\% do peso corporal), devido a subalimentação, estão relacionadas com anestro em vacas de corte. O ECC pode ser usado como um indicador de balanço energético no início da lactação, porque a mobilização de gordura provoca alteração na condição corporal.

Segundo Wright et al. (1992b), em gado de corte a condição corporal ao parto influência a freqüência de pulsos de LH no pós-parto e este efeito parece estar ligado à freqüência de liberação do $\mathrm{GnRH}$ pelo hipotálamo e conseqüente crescimento folicular.

De Kruif (1993) afirma que o excesso de concentrado ao final da lactação e período seco resulta em condição corporal elevada, acarretando nestas fêmeas uma maior predisposição para a ocorrência de síndrome da vaca gorda, bem como outras doenças do periparto que afetam a fertilidade. $O$ autor conclui que devem ser proporcionados altos consumos de energia após o parto e limitar a energia na dieta durante o final da lactação e período seco, para se obter maximização do desempenho reprodutivo.

Quando se alimenta a vaca em excesso no período seco, há um aumento da condição corporal ao parto. Este aumento de peso provoca uma perda do apetite após o parto (Fronk et al., 1980; Garnsworthy \& Topps, 1982; Vann Den Top, 1995), o que acarreta em maior e profundo balanço energético negativo (Rukkwamsuk et al., 1998), aparecendo grandes quantidades de ácidos graxos livres circulantes que devem ser metabolizados pelo fígado. Quando há um aumento da lipólise, ocorre aumento dos ácidos graxos livres provenientes do tecido adiposo, saturação da capacidade oxidante do fígado e acúmulo destes ácidos nos hepatócitos, fator importante para o desenvolvimento de fígado gorduroso. Sendo assim, Rukkwamsuk et al. (2000) observaram haver diferente percentagem dos ácidos graxos dentro do fígado, e 
estes são mudados intensamente quando a lipólise aumenta, esta mudança é mais pronunciada nas vacas que desenvolvem fígado gordo.

Devido à concentração de gordura do leite tender a aumentar no início da lactação e a proteína tender a diminuir nos períodos de BEN no pós parto, sugeriu-se que a proporção de gordura/proteína poderia ser um indicador potencial da deficiência energética. Além disso, houve alta relação gordura/proteína com deslocamento de abomaso para esquerda, o qual aumentou em 8,6 vezes (Heuer et al., 1999).

\subsection{Distúrbios metabólicos}

A maioria dos problemas metabólicos da vaca leiteira no pós-parto (cetose, hipocalcemia, esteatose hepática), infecciosos (metrites e mastites) e decorrentes dos distúrbios metabólicos (deslocamento do abomaso, retenção de placenta e laminite) ocorrem durante o período de transição. Estes problemas podem diminuir o pico de produção de leite em 5 a $10 \mathrm{~kg}$ de leite/dia, totalizando de 1000 a $2000 \mathrm{~kg}$ de leite perdido durante toda a lactação. Estes distúrbios também podem provocar diminuição do desempenho reprodutivo, resultando em perdas econômicas adicionais (Holcomb et al., 2001).

Além das características intrínsicas do período de transição, os últimos dias de gestação coincidem com a formação do colostro, crescimento fetal, e das membranas fetais, os quais aumentam as exigências de glicose, aminoácidos, ácidos graxos, minerais e vitaminas pelo tecido mamário (Grummer, 1995 e Bertics et al., 1992).

Durante a gestação, predominam altos níveis de progesterona, porém na fase final, observa-se a participação de outros hormônios envolvidos na síntese do colostro e lactogênese. Incluem-se entre estes hormônios a prolactina, ACTH (hormônio adrenocorticotrófico), progesterona, estrógeno, prostaglandinas e hormônio do crescimento, cujas concentrações estão 
diretamente relacionadas com a proximidade do parto. No contexto, tem-se observado um aumento considerável da prolactina, ACTH e prostaglandinas 24 a 48 horas antes do parto. O aumento desta última substância provoca lise do corpo lúteo gestacional e como conseqüência, diminuição dos níveis de progesterona, permitindo assim a ligação da prolactina ao tecido mamário, intensificando a lactogênese (Reece, 1996).

A insulina plasmática diminui e o nível do hormônio de crescimento aumenta, na medida em que se aproxima a data do parto e início de lactação, com uma elevação aguda de ambos, hormônios no parto (Kunz et al., 1985) e da glicose (Grummer, 1995), a qual pode ser devido ao efeito do cortisol, aumentando a gliconeogênese hepática. A tiroxina plasmática aumenta gradualmente durante o final da gestação, diminuindo aproximadamente em $50 \%$ ao parto, para então iniciar um novo aumento (Kunz et al., 1985), visando manter a lactação (Reece, 1996).

Os estrógenos, principalmente a estrona de origem placentária, aumentam durante a gestação, porém diminuem imediatamente ao parto. A concentração da progesterona, durante o período seco, se mantém elevada com o intuito de manter a prenhez, declinando rapidamente dois dias antes do parto (Chew et al., 1979). Os glicocorticóides e a prolactina aumentam sua concentração no dia do parto e, retornam logo após, a concentrações basais (Edgerton e Hafs, 1973).

Estas mudanças, as quais são mais acentuadas que em qualquer outro período dentro do ciclo de gestação e lactação, têm influência no metabolismo tecidual e utilização de nutrientes (Grummer, 1995).

O suprimento energético aos tecidos é feito continuamente, através da oxidação de compostos de carbono. Entretanto, apenas um número limitado destes compostos podem ser oxidados pelas células, mesmo sendo oferecidos de forma constante pela corrente sangüínea, o que permite o transporte e interconversão entre carboidratos, lipídios e proteínas. Quando este sistema falha, surgem os chamados transtornos no metabolismo da energia (Lago, 
1997). Após o parto, a situação é mais delicada, devido a demanda súbita de nutrientes para a produção de leite, sem que haja um devido aumento na capacidade de ingestão de matéria seca, provoca uma intensa mobilização de reservas corporais, principalmente gorduras (Komaragiri \& Erdman, 1995), gerando como resultado altos níveis de $A G L$ circulantes, com conseqüente infiltração no tecido hepático ( Studer et al., 1993; Vasquez-Añon et al., 1994). Para Drackley (1999), os níveis de AGL em animais com balanço energético positivo devem estar em torno de $200 \mu \mathrm{eq} / \mathrm{L}$, durante o período próximo do parto este valor se situa em torno de 200 a 300 e atingem os valores de 800 a $1200 \mu \mathrm{eq} / \mathrm{L}$ dois dias antes do parto até 3 dias após parto, isto é devido ao estresse do parto e ação de hormônios.

O exato mecanismo para essa depressão no consumo de alimento não é completamente entendido, todavia, há hipótese de que o efeito físico dos depósitos de gordura abdominal, a maior concentração de triglicerídeos hepáticos, o maior nível circulante de ácidos graxos não esterificados e de corpos cetônicos em vacas obesas, possam reduzir o apetite e ocasionar a queda no consumo de MS nas últimas semanas pré-parto, e nas primeiras semanas pós-parto (Garnsworthy, 1988; Garnsworthy \& Topps, 1982).

As mudanças endócrinas e a diminuição na ingestão de matéria seca durante o final da gestação, influenciam o metabolismo e levam a uma mobilização de gordura do tecido adiposo e glicogênio hepático. Em decorrência disto, observa-se um aumento dos ácidos graxos não esterificados (NEFA), em até 3 vezes ou mais, nas duas a três semanas que antecedem ao parto e 2 a 3 dias antes do parto, momento em que a concentração dos AGL aumenta significativamente até se completar o parto (Bertics et al.,1992; Vasques-Añon, 1994; Grum et al., 1996).

Em parte, o aumento inicial de NEFA pode ser responsável pelas mudanças endócrinas, semelhantes com a restrição alimentar resultando em diminuição da ingestão de matéria seca. 
A alimentação forçada durante o período de transição próximo ao parto reduziu a magnitude do aumento do NEFA, porém, não o eliminou completamente (Bertics et al., 1992). Estas observações indicam que, no mínimo em parte, o aumento plasmático pré-parto de NEFA é hormonalmente induzido. Contudo, a elevação súbita de NEFA no dia do parto, talvez seja devido ao estresse provocado pelo parto, principalmente devido aos esforços da parição, ausência ou diminuição da ingestão de alimento neste dia e endocrinamente, no mecanismo do parto, estão envolvidos hormônios como ACTH e estrógenos que podem estar envolvidos na lipólise. Após o parto, os níveis plasmáticos de NEFA diminuem rapidamente, porém, permanecem maiores do que aqueles observados antes do parto (NRC, 2001). Por esta razão, deve-se procurar maximizar a ingestão de matéria seca antes do parto, prevenindo assim desordens metabólicas pós-parto.

Bertics et al. (1992) avaliaram os efeitos da diminuição da ingestão de alimentos no pré-parto e o desenvolvimento de fígado gorduroso. Para isto, utilizaram 11 vacas alimentadas à vontade no pré-parto que foram usadas como controle. Outras 11 foram mantidas no mesmo nível de ingestão de matéria seca, porém com alimentação forçada das sobras via cânula ruminal, durante os 17 a 21 dias pré-parto. A ingestão de alimento declinou em 18\% nas vacas controle nos 17 dias finais do pré-parto. Os triglicerídeos hepáticos das vacas que receberam alimentação forçada via fístula ruminal aumentaram $75 \%$ entre os dias 17 pré-parto e 1 dia pós-parto, enquanto que nas vacas controle, este aumento foi de $225 \%$, com diminuição da ingestão de alimento.

Resultados de numerosos estudos indicam que vacas obesas apresentam pouco apetite no pós-parto (Garnsworty \& Jones, 1987 e Holter et al., 1990), e que a ingestão de alimento no pós-parto está relacionada com a ingestão de alimento no pré-parto, o que pode também sugerir que as vacas obesas poderiam também, comer menos no pré-parto (Grummer, 1995). Emery (1993) observou um coeficiente de correlação de -0,25 e 0,45 entre condição 
corporal pré-parto e ingestão de matéria seca em 1 dia pré-parto e 21 dias pósparto, respectivamente.

Uma alternativa para minimizar os efeitos do deficite de energia provocada pela redução da ingestão de MS, no período de transição, pode ser o aumento da densidade energética da dieta, usando maiores quantidades de CNF (carboidratos não fibrosos), o que pode proporcionar uma maior concentração de propionato no rúmen (Batajoo et al., 1994), podendo promover secreção de insulina (Harmon, 1992). Levando-se em consideração que insulina é anti-lipolítica, um aumento na quantidade de CNF na dieta poderá acarretar em uma diminuição dos AGL plasmáticos e reduzir a conversão hepática de triglicerídeos a corpos cetônicos (Rabelo et al., 2001). Segundo Dirksen et al. (1985), outra vantagem de aumentar a quantidade de CNF na dieta do pré-parto é aumentar o desenvolvimento das papilas ruminais e a capacidade de absorção dos AGV, condição essencial para minimizar o acúmulo destes ácidos, redução do $\mathrm{pH}$, evitando a acidose no pós-parto. Entretanto, quando se aumenta os CNF na dieta pode-se desencadear mudanças positivas, porém, dietas que provocam pouco enchimento ruminal estão relacionadas com maior incidência de deslocamento de abomaso para esquerda (Shaver, 1997).

Rabelo et al. (2001) avaliaram o efeito do aumento da densidade energética na dieta em vacas no pré-parto e não observaram diferença na ingestão de MS para os grupos de alta e baixa densidade energética. No obstante, observaram que as dietas altas em energia aumentaram a concentração total dos AGV no fluído ruminal em relação ao grupo de baixa densidade energética. A concentração de propionato e insulina foram maiores nas vacas alimentadas com dietas de alta densidade energética e, também apresentaram menores concentrações de AGL plasmáticos antes e após alimentação. Os autores concluíram que, o aumento da densidade energética da dieta das vacas no período seco afetou positivamente a ingestão de MS, 
propionato ruminal, insulina sérica e AGL plasmáticos, o que pode ser útil, como estratégia para fornecer maiores quantidades de precursores gliconeogênicos.

Em termos nutricionais, quando se muda a dieta de alto nível de concentrado para dieta alta em fibra, causa alteração na característica da população microbiana e do epitélio ruminal. Dietas ricas em concentrado favorecem as bactérias que utilizam o amido e a produção de propionato e lactato; dietas altas em fibra favorecem as bactérias celulolíticas e produção de metano e diminuem aquelas que produzem propionato e utilizam lactato.

A introdução súbita de grãos logo após o parto, tem algumas conseqüências deletérias; a produção do lactato aumenta antes de se restabelecer a capacidade da sua utilização pelas bactérias, havendo uma redução do $\mathrm{pH}$, com isso os ácidos graxos são absorvidos mais rapidamente (Goff \& Horst, 1997b).

Os produtos finais da fermentação influenciam o crescimento das papilas ruminais (Dirksen et al., 1985); estas são responsáveis pela absorção dos ácidos graxos voláteis (AGV). Ao se aumentar os grãos na dieta e a concentração de propionato no rúmen se promove um crescimento destas papilas, contudo dietas ricas em fibras causam um encurtamento das mesmas. No máximo $50 \%$ da área de absorção do rúmen pode ser perdida durante as 7 primeiras semanas do período seco e o crescimento das papilas após a reintrodução de concentrados requer algumas semanas (Dirksen et al., 1985). Outra alternativa, além da densidade energética e diminuição do conteúdo de fibra na dieta, é agregar suplemento de gordura ou ambos e ainda adição de suplementos energéticos ou substâncias gliconeogênicas, porém, Staples et al. (1997) relataram que com dietas contendo $55-60 \%$ de grãos observou-se um aumento linear no consumo de energia. Porém, com mais de $60 \%$ de concentrado e quantidades limitadas de fibras, há maior osmolaridade ruminal, menor $\mathrm{pH}$, aumento de AGV no rúmen e no sistema porta, bem como diminuição da ingestão de MS. 
Dirksen et al. (1985) demonstraram que a redução da percentagem de fibra na dieta do pré-parto aumentava o desenvolvimento das papilas ruminais e da capacidade de absorção de ácidos graxos voláteis do rúmen. Isto evitava a diminuição do pH ruminal e também a acidose que, é característica do uso de grãos nas dietas no pós-parto. Outro aspecto muito importante diz respeito à maior produção de propionato no rúmen quando se incrementa o uso de grãos. O propionato é convertido à glicose pelo fígado e, ambos propionato e glicose, estimulam a produção de insulina pelo pâncreas. A função endócrina do pâncreas, no ruminante, é secretar insulina, glucagon, somatostatina e polipeptídeo pancreático, que podem ser mediados através de efeitos parácrinos e efeitos nutricionais (Harmon, 1992). Dos efeitos nutricionais, podese mencionar a influência dos AGV que estimulam a secreção pancreática de insulina e glucagon, a qual foi observada após injeção endovenosa de propionato e butirato em ovinos; este fenômeno parece ser único para ruminantes (Manns \& Boda, 1967 e Horino et al., 1968). A insulina é um hormônio antilipolítico, o qual pode ajudar a reduzir a mobilização de triglicerídeos das reservas corporais.

Durante o período transicional, observa-se que os neutrófilos e linfócitos têm sua função deprimida, e a concentração de outros componentes do sistema imunológico se encontram diminuídos. Talvez, isto se deva a ação dos glicocorticóides e estrógenos que são imunosupressores, e se encontram elevados no plasma com a aproximação do parto (Goff \& Horst, 1997b). O consumo de vitamina $\mathrm{A}$ e $\mathrm{E}$, e outros nutrientes essenciais para função imune pode estar diminuído pela redução no consumo de MS observado no período de transição (NRC, 2001). Esta é a razão pela qual se observa um aumento da mobilização das reservas corporais e a infiltração de gordura no tecido hepático no período de transição (Vazquez-Añon et al., 1994 e Studer et al., 1993), que associadas ao déficit de glicose levou a um aumento na produção de corpos cetônicos (CC). O aumento dos $\mathrm{CC}$ podem ser detectados no sangue, urina e 
leite e dependendo da sua magnitude leva a uma condição conhecida como cetose (Hibbit, 1979; Baird, 1982 e Drackley et al., 1992)

\subsubsection{Cetose}

Quando as demandas do animal ultrapassam a ingestão de nutrientes e o balanço energético torna-se negativo, há um aumento na taxa de lipólise e diminuição na lipogênese. O resultado final é um aumento na hidrólise de triglicerídeos pela enzima lipase sensível a hormônio (LSH), tendo como conseqüência uma maior liberação de glicerol e ácidos graxos livres (AGL). O glicerol é rapidamente utilizado pelos tecidos sendo incorporado no ciclo de Krebs. Os AGL resultantes da hidrólise de triglicerídeos pela LSH são transportados pela corrente sangüínea ligados à albumina. Esses AGL podem ser utilizados como fonte de energia pelos tecidos musculares, como precursores de gordura do leite pela glândula mamária ou então direcionados para o fígado. No fígado, os AGL podem ser completamente oxidados a $\mathrm{CO}_{2} \mathrm{e}$ a energia é liberada; ou podem ser parcialmente oxidados a acetil-CoA, gerando corpos cetônicos ou ainda ser utilizados para síntese de triglicerídeos, dos quais a maior parte é incorporado ao tecido hepático (Santos \& Santos, 1998).

Nas vacas de alta produção, a cetose ocorre normalmente entre os 10 dias e 6 semanas após o parto; há, todavia um pico de ocorrência por volta de 3 semanas após o parto (Grummer, 1993). É um problema metabólico associado diretamente ao suprimento inadequado de energia, observado em vacas leiteiras de alta produção, no início de lactação (Gustafsson, 1993), caracterizado por queda na concentração de glicose e aumento excessivo de corpos cetônicos no sangue. Esta condição é denominada de acetonemia, podendo se apresentar de forma clínica ou sub-clínica (Lean et al., 1991). A forma sub-clínica é diagnosticada em função das concentrações sangüíneas de B-HBA (beta-hidróxido-butirato), oriundo da beta-oxidação dos ácidos graxos, 
seguidos pela condensação de acetil-CoA, formando acetoacetil-CoA, que por ação enzimática no ciclo de Krebs forma-se o Beta-hidróxido-butirato (B-HBA).

Segundo Drackley (1999), a beta-oxidação dos ácidos graxos de cadeia longa, entre eles os AGL, ocorre no interior da mitocôndria e sua entrada é mediada pelos transportadores carnitina palmitotransferase I (CAT I) e II (CAT II). Uma vez no interior da mitocôndria, a beta-oxidação produz acetil-CoA, proveniente da oxidação dos ácidos graxos e a baixa disponibilidade de oxalato durante o início de lactação, favorecem o direcionamento no sentido da formação de acetoacetil-CoA e posteriormente, acetoacetato e B-hidroxibutirato.

A cetose é considerada positiva pela maioria dos autores, quando as concentrações de B-HBA estiverem acima de 10mg/dL (Santos, 1996; Lago, 1997 e Green, 1999). Os sintomas clínicos incluem sinais de hipofagia, queda na produção de leite, perda rápida de peso, hálito cetótico característico, hipoglicemia, hipoinsulinemia, altos níveis de AGL, letargia, sintomas nervosos e as vezes morte (Guard, 1995 e Veenhuizen et al., 1991).

A retirada dos $A G L$ da circulação sangüínea é realizada pelo fígado e, está diretamente relacionada com sua concentração na corrente circulatória (Lean, 1991; Bauchart, 1993 e Grummer, 1993). Uma vez absorvidos pelo fígado, podem passar por: oxidação completa, incompleta ou síntese de triglicerídeos. A oxidação completa dos AGL produz energia em forma de ATP e $\mathrm{CO}_{2}$ via ciclo de Krebs e cadeia respiratória, exigindo para isto a disponibilidade de oxalacetato, para que o acetil-CoA possa ser oxidado. A oxidação incompleta do acetil-CoA produz como produto final os corpos cetônicos, acetoacetato e beta-hidroxibutirato (Lean et al., 1992 e Reynolds et al., 1988). Outra fonte de beta-hidroxibutirato é o butirato produzido no rúmen que, é total ou parcialmente oxidado pelo epitélio ruminal a $\mathrm{CO}_{2}$ ou trasformado em betahidroxibutirato, portanto, tornando o fígado e o epitélio ruminal as fontes mais importantes de corpos cetônicos em ruminantes.

A incidência de acetonemia em rebanhos leiteiros varia conforme os autores, assim Dohoo et al. (1984), no Canadá, encontraram incidência de 9,6\% 
dos animais com níveis plasmáticos acima do normal. No mesmo país, Duffield et al. (1995) encontraram $14,1 \%$ dos animais com concentrações médias de $10,4 \mathrm{mg} / \mathrm{dL}$, caracterizando a presença do problema nos rebanhos analisados. Valores de 3,7\% na incidência foram reportados por Jordan \& Fourdraine, (1993) analisando 61 rebanhos americanos, com uma variação de 0 a $20 \%$, e constataram ainda uma prevalência de $7,2 \%$ de febre do leite (0 a $44,1 \%$ ) e $3,3 \%$ de deslocamento de abomaso (0 a 14\%).

Nos E.U.A., a incidência de animais acometidos por cetose varia de 4 a $7 \%$ e destes $1 \%$ morre, $5 \%$ são descartados e apresentam perdas na produção de leite da ordem de $200 \mathrm{~kg}$ por lactação, representando um custo médio de U $\$ 145,00$. As perdas são ainda maiores se considerar que a maioria dos animais desenvolvem a cetose sub-clínica, portanto, não diagnosticadas (Schlatter, 1997).

No Brasil, existem poucos dados de pesquisas referentes à ocorrência de cetose em bovinos leiteiros, porém, Magalhães \& Belém (1995) observaram uma incidência de $18,8 \%$ de casos positivos de um total de 22 vacas estudadas, nas primeiras seis semanas pós-parto. Porém, Castillo (1994), analisando a presença de acetona e acetoacetato no leite no início da lactação, não encontrou nenhum caso positivo, tendo-se argumentado que, o alto consumo de alimentos concentrados poderia explicar o fato. Lago (1997) encontrou uma incidência de $13,56 \%$ de cetose sub-clínica e $0,84 \%$ cetose clínica. Entretanto, Fonseca (1997) observou uma prevalência de $21,7 \%$ de cetose clínica, considerado pelo autor estar acima das médias registradas por outros autores.

De acordo com Grummer (1993), a ocorrência de acetonemia, esta geralmente associada com esteatose hepática, e a susceptibilidade é máxima durante períodos de maior produção de leite, em que há grande demanda por glicose, observando-se hipoglicemia, e hipoinsulinemia. No início da lactação as vacas leiteiras estão em BEN, e estão especialmente dependentes da 
gliconeogênese hepática (Young, 1977), período em que a função hepática esta comprometida.

Gerloff et al. (1986), estudaram 9 rebanhos no estado de Michigan (USA), utilizando a biopsia hepática no pré e pós-parto, observaram $20 \%$ dos animais com lipidose moderada, $15 \%$ com lipidose severa, sendo que o primeiro grupo apresentou 5 a $10 \%$ e segundo acima de $10 \%$ de triglicerídeos no fígado. Os animais com lipidose severa apresentaram concentrações de AGL no soro superior aos demais durante e após o parto, enquanto que os animais com lipidose moderada apresentaram concentrações superiores aos de lipidose branda apenas no pós-parto.

A concentração de AGL é o principal fator determinante de acúmulo de triglicerídeos no fígado (Bell, 1981). Durante o período próximo ao parto, as concentrações de AGL em bovinos leiteiros aumentam em aproximadamente 1 mM (Bertics, 1992).

Em animais que estão em balanço energético positivo, o principal substrato para cetogênese hepática é o butirato, já nos períodos de alta demanda energética e balanço negativo de energia, há um aumento da lipólise e conseqüente aumento de AGL sangüíneo, estes ácidos graxos tornam-se os precursores cetogênicos mais importantes (Zammit, 1990). No fígado, os AGL são esterificados e exportados para a circulação e utilizados nos tecidos via VLDL (lipoproteína de muito baixa densidade) ou, armazenados no parênquima hepático, mais especificamente na forma de vacúolos de gordura no citoplasma dos hepatócitos (Maclachlan \& Culen, 1990). Entretanto, a vaca leiteira tem uma capacidade hepática limitada para sintetizar VLDL; além do mais, é pouco responsiva aos aumentos na taxa de esterificação de ácidos graxos no fígado (Kepple et al., 1988 e Pullen et al., 1990), e este é o fator principal que, contribui para desenvolvimento do fígado gordo (Bertics et al., 1992). Herdt (1988) tem sugerido que altos níveis de triglicerídeos no fígado predispõe à alteração da função hepática, redução no consumo de alimento, baixa produtividade e baixo desempenho reprodutivo. 
Segundo Grummer (1993) e Vazquez-Añon et al. (1994), a esteatose hepática ou fígado gorduroso ocorre quando a taxa de síntese de triglicerídeos, no fígado é maior que a capacidade de exportação, quer seja por hidrólise ou por transporte via VLDL. Os fatores que regulam o destino dos AGL no fígado são pouco conhecidos, no entanto, fatores que diminuem a oxidação geralmente aumentam a esterificação (Grummer, 1993).

De acordo com Grummer (1993), a ocorrência de acetonemia está geralmente associada com esteatose hepática. A susceptibilidade à esta desordem é máxima durante períodos de maior produção de leite, em que há grande demanda por glicose, observando-se hipoglicemia, e hipoinsulinemia.

A cetose é uma doença comum em vacas de alta produção, porém, nem sempre é observada clinicamente, podendo estar afetando a produção (Gustafsson, 1993) e reprodução (Andersson, 1991). Conforme mencionado anteriormente, a função reprodutiva está estreitamente relacionada com a deficiência de energia e as mudanças metabólicas e hormonais que ocorrem no pós-parto.

As vacas que parem obesas mobilizam mais gordura corporal, desenvolvem fígado gorduroso, e esta condição está associada com longos intervalos para a primeira ovulação e fertilidade diminuída (Butler \& Smith, 1989 e Rukkwamsuk et al., 1999), devido ao longo período de balanço energético negativo a que estão sujeitas (Garnsworthy et al., 1988; Gearhart et al., 1990; Ferguson, 1991; Fergusson et al., 1994; Garnsworthy et al., 1997).

Altas concentrações de corpos cetônicos (CC) no sangue também foram relacionadas com redução na fertilidade (Benjaminsen, 1977, citado por Baird, 1982), o que sugere uma interferência da cetose na reprodução. Por outro lado, Anderson \& Emanuelson (1985) não encontraram relação entre o pico de concentração de acetona no leite e o intervalo entre o parto e o primeiro serviço. Porém, Butler \& Smith (1989) sugeriram um efeito negativo de altos níveis circulantes de $\mathrm{CC}$ sobre o hormônio liberador de gonadotrofina hipotalâmica $(\mathrm{GnRH})$, o que segundo os autores explicaria o maior período de 
serviço, observado nos animais com altas concentrações de CC circulantes. $\mathrm{Na}$ mesma linha de pesquisa, Andersson \& Gustafsson (1991), analisando 15438 vacas em 471 rebanhos, verificaram que, vacas com altos níveis de acetona no leite apresentavam maior freqüência de cistos ovarianos e maior período de serviço. Também na Suécia, Emanuelson et al. (1993), estudando vacas de 1692 rebanhos daquele país, puderam confirmar estes resultados e verificaram que a cetose aumentava o risco de ocorrer disfunções ovulatórias. Da mesma forma, Dohoo \& Martin (1984) também relataram que a cetose aumentava o risco de ocorrerem infecções uterinas e cistos ovarianos e Kuzma et al. (1994) verificaram a diminuição na eficácia do tratamento para ovários císticos.

Nos ruminantes, aminoácidos e propionato são os principais glicoprecursores, embora, lactato e glicerol também sejam utilizados (Reynolds et al., 1994). Há, contudo, necessidade de lembrar-se que, no início da lactação, o consumo reduzido de alimentos não fornece quantidades suficientes de aminoácidos e de propionato que, em primeira instância devem atender às exigências de glicose na glândula mamária.

Alimentar a vaca durante este período é um desafio, pois trata-se de uma fase marcada por mudanças endócrinas, responsáveis pela preparação da fêmea para o crescimento final do feto, parto e lactogênese (Grummer, 1994). Embora uma dieta bem balanceada possa reduzir os problemas no período de transição, este programa ficará comprometido caso haja diminuição de consumo, o que acarreta uma deficiência de energia e outros nutrientes. Neste contexto, a administração oral forçada de nutrientes pode ser uma ferramenta útil para aumentar os níveis de cálcio sangüíneos, minimizar o deficite de energia, reidratar o animal e estimular a fermentação ruminal (Stokes \& Goff, 2001). 


\subsection{Período de transição}

A produção de leite esperada de uma lactação começa a se configurar no período pré-parto ou período seco, que se refere a uma fase preparatória ou de transição, período este de pequenas exigências para um período de grandes demandas metabólicas, para síntese de colostro e grandes quantidades de leite. Esta fase de ajuste coincide com muitas alterações endócrinas e metabólicas que, quando não bem coordenadas, podem acarretar problemas metabólicos e infecciosos, tais como: hipocalcemia, cetose, deslocamento de abomaso, retenção de placenta, laminite e mastite.

Segundo Grant \& Albright (1995), o período de transição pode ser dividido em duas fases distintas, de 5 a 7 dias pré-parto, caracterizado por uma redução de $30 \%$ na ingestão de matéria seca, e de 0 a 21 dias pós-parto, durante o qual a ingestão de matéria seca poderá aumentar rapidamente. Observações semelhantes foram feitas por outros autores (Coppock et al., 1972; Lodge et al., 1975 e Jourment \& Remond, 1976). Por outro lado, o período de transição, segundo Schlatter (1997), varia de 3 semanas antes do parto a diferentes períodos pós-parto.

Segundo Grummer (1994), alimentar a vaca no período de transição é um desafio, já que se trata de uma fase marcada por mudanças endócrinas e metabólicas provenientes das necessidades da fêmea de suprir o crescimento final do feto, parto e lactogênese. O autor observou, no mesmo período, uma diminuição no consumo de MS de até $30 \%$, o que naturalmente leva a uma deficiência energética quantitativa, com conseqüente perda de peso e econômicas (Grummer, 1998).

Em função destas observações, Grummer (1995) propôs maximizar a ingestão de matéria seca no pós-parto, de forma a reduzir a mobilização de tecido adiposo e prevenir a retirada excessiva de glicogênio hepático. Porém, dados de pesquisas, demonstraram ser inevitável uma diminuição no consumo de matéria seca no período de transição, havendo variação na sua magnitude e 
duração (Copock et al., 1972; Kunz et al., 1985; Grummer, 1995). A conseqüência direta é um desempenho reprodutivo comprometido, particularmente a possibilidade de uma nova gestação poder estar associada negativamente com a magnitude e severidade do balanço energético negativo característico do início da lactação (Butler \& Smith, 1989; Nebel \& McGilliard, 1993).

Após o parto, as vacas leiteiras experimentam um lento aumento na ingestão de matéria seca, um rápido aumento na produção de leite e aumentam a mobilização de tecido adiposo corporal (Garnsworth, 1998; Butler \& Smith, 1989; Gearhart et al., 1990; Van Saun, 1991; Nebel \& McGilliard, 1993), fenômeno este que pode ser observado em $80 \%$ das vacas no início da lactação, devido à demanda de energia para a produção de leite estar acima da consumida na dieta.

$\mathrm{Na}$ maioria dos casos, o balanço energético negativo extremo ocorre durante a primeira e segunda semanas de lactação (Villa-Godoy et al., 1988; Butler \& Smith, 1989; Zurek et al., 1995), observando-se um equilíbrio entre demanda e o consumo de nutrientes por volta de 40 a 50 dias de lactação (Staples et al., 1990; De Vries \& Veerkamp, 2000), período em que o balanço energético está próximo de zero.

Butler \& Smith (1989) observaram uma alta correlação negativa entre balanço energético médio e produção de leite $(r=-0,8)$, sugerindo que animais de maior mérito genético estariam, inevitavelmente, sujeitos a ovulações tardias. Assim sendo, Villa-Godoy et al. (1988), observaram que as vacas no início da lactação, a variação no balanço energético negativo médio esteve mais intimamente relacionada com consumo de matéria seca do que com produção de leite ( $r=0,73$ e $r=-0,25$, respectivamente). Esta condição também foi observada por Staples et al. (1990), os quais verificaram que, vacas em anestro, consumiram 2,5 a 3,6 kg de MS menos que as vacas que estavam ciclando. O atraso no ressurgimento da atividade cíclica ovariana está diretamente relacionada com o "status" energético do animal (Santos, 1996; 
Beam \& Butler, 1997 e 1998). Assim, quanto antes ocorrer a primeira ovulação pós-parto, maior será o número de ciclos estrais que ocorrem durante o período de espera voluntária, havendo também maior expressão de sinais clínicos de cio e aumento da fertilidade a primeira inseminação (Thacher \& Wilcox, 1973).

Para Roche et al. (2000), quando a vaca leiteira pós-parto retira reserva corporal para balancear seu estado energético, esta mobilização de gordura é o maior fator de risco associado com períodos anovulatórios prolongados. Entretanto, Kadokawa et al. (2000) afirmam que não é certo se a mobilização de gordura por si só pode afetar o tempo da primeira ovulação pós-parto. Uma das razões para esta incerteza é que se conhece muito pouco sobre o mecanismo fisiológico que liga atividade do tecido adiposo e o eixo reprodutivo.

Tem-se observado que, durante o período de balanço energético negativo, a glicemia, insulinemia e também os níveis de IGF1 estão baixos, bem como as freqüências dos pulsos de $\mathrm{GnRH}$ e $\mathrm{LH}$. Por outro lado, as concentrações plasmáticas de progesterona também são afetadas pelo BEN em vacas leiteiras. Estudos in vivo e in vitro demonstraram que estes hormônios afetam a foliculogênese, ovulação e produção de esteróides (Santos, 1998).

Conforme citado anteriormente, o efeito do BEN sobre a função ovariana pós-parto pode ser mediada pelo fator de crescimento semelhante a insulina (IGF-I) (Spicer et al., 1990 e Butler, 2000); mais recentemente, um sinal direto do tecido adiposo a leptina tem também sido proposta. Trata-se de um hormônio produzido principalmente pelos adipócitos, o qual regula o consumo de alimento, agindo como sinal metabólico, no sistema nervoso central que atuaria nos núcleos que controlam a liberação pulsátil do hormônio luteinizante (Cunningham et al., 1999 e Blache et al., 2000a).

Para Stephenes et al. (1995), a leptina é uma proteína de 16K-D, (quilo daltons), produto do gene obeso produzido primariamente pelo tecido adiposo, o qual exerce um importante papel na regulação do consumo de alimento e peso corporal. Como um hormônio que interage na saciedade, suas concentrações podem mudar em respostas ao consumo de calorias, suprimindo 
o apetite, aumentando a taxa metabólica, regulando o ganho de peso e deposição de gordura (Considine et al., 1996; Granowitz, 1997 e Zhang et al., 1994). Estudos em humanos demonstraram uma correlação positiva entre a liberação e síntese de leptina e índice de massa corpórea ou percentagem de gordura corporal (Ahima et al., 1996; Sinha et al., 1996 e Nagatani et al., 2000).

A leptina parece ser responsável por mudanças na secreção de LH em animais que estão em balanço energético negativo. Em bovinos, poucos estudos têm sido feitos, mas o jejum tem mostrado que a leptina suprime a síntese e reduz a atividade pulsátil do LH em novilhas pré-púberes (Amstalden et al., 2000). Durante o período de BEN, tem-se observado algumas alterações na concentração de hormônios ligados à função reprodutiva. Neste sentido, o tratamento com leptina impediu a queda da freqüência do pulso de LH induzido pelo jejum em macacos, ratos e ovinos machos tratados com estradiol (Finn et al., 1998; Nagatani et al., 1998 e 2000).

Para alguns autores, os resultados de pesquisas sugerem que a leptina é um importante regulador das funções reprodutivas e pode ser um indicador da ligação entre "status" nutricional e reprodução (Smith et al., 2002).

\subsubsection{Suplementação com produtos energéticos no período de transição}

As constatações científicas da importância sobre o período de transição em vacas leiteiras de alta produção são claras no que diz respeito as grandes e complexas mudanças endócrino-metabólicas que, comprometem de diversas maneiras, a produção e a eficiência reprodutiva, energética dependentes. A hipofagia, lipólise e disfunções ovarianas pós-parto são resultados da deficiência energética no período de transição.

A maior fonte de energia para os ruminantes são os ácidos graxos voláteis (AGV) encontrados no rúmen, provenientes quase que em sua totalidade, da fermentação dos carboidratos dietéticos. A concentração total de AGV no rúmen, e a respectiva quantidade de cada um depende tanto da 
composição da ração, nível de consumo e manejo alimentar. Dietas ricas em amido e sacarose favorecem a formação do ácido propiônico, um precursor de glicose, cuja síntese é feita por dois mecanismos; o primeiro envolve a formação de oxaloacetato e succinato e o segundo envolve a formação do acrilato.

Muitas pesquisas têm sido realizadas com gorduras inertes e ionóforos como a lasalocida e monensina, produtos de fermentação de vários actinomicetos, cujo modo de ação difere da maioria dos antibióticos; basicamente alterando os movimentos dos íons através das membranas biológicas, podendo afetar bactérias, protozoários e fungos (Russel, 1997). Algumas substâncias gliconeogênicas foram inicialmente utilizadas em ruminantes, estritamente com fins terapêuticos, como a glicerina (Glicerol) e o propileno glicol, utilizadas no tratamento de acetonemia da vaca leiteira, acetonemia gestacional dos ovinos e como terapia de suporte. Não é prática recente, já que os primeiros trabalhos datam da década de 50 (Johnson, 1954; Maplesden, 1954, citados por Juchem, 2000).

Nos últimos anos, tem aumentado o interesse pelo uso de propileno glicol administrado oralmente em vacas no período de transição com o objetivo de reduzir a incidência de cetose e aumentar as concentrações plasmáticas de glicose, insulina, colesterol e IGF1 (Canfield et al., 1990; Grummer et al., 1994 e Formigoni et al., 1996).

O propileno glicol ou 1,2-propanodiol é um álcool de aparência cristalina e oleosa, gliconeogênico, usado para tratar cetose pós-parto, pois quando administrado por via oral, escapa intacto da fermentação ruminal, quase na sua totalidade, é absorvido no intestino e transformado em glicose no fígado, primeiramente pela rota do lactoaldeído com subsequente oxidação a lactato (Studer et al., 1993). Waldo \& Schultz (1960) encontraram maior aumento de glicose sangüínea com o uso de propileno quando comparou, propileno glicol, propionato de sódio, lactato de sódio, mistura de lactato e sucrose administrado intraruminalmente. Os autores sugeriram que, a maior glicemia foi 
provavelmente devido à absorção direta mais absorção dos produtos de fermentação. O aumento na produção de leite foi menor para o propileno quando comparado com propionato de sódio. Por suas características, têm sido utilizado, sobretudo, na forma de "Drench" (ingestão forçada), embora, alguns trabalhos tenham avaliado sua inclusão na dieta total ou no concentrado (Sauer et al., 1973; Formigoni et al., 1996 e Fonseca et al., 1997).

Waldo \& Schultz (1960) avaliaram o comportamento ruminal e sangüíneo de vacas recebendo, entre outros energéticos, o propileno glicol. Este produziu a maior resposta em glicose sangüínea (60 mg/dL) e a segunda em ácido propiônico ruminal (+ $76 \mathrm{mg} / 100 \mathrm{~mL}$ ). Os autores concluíram que, o efeito hiperglicêmico do propileno glicol era conseqüência, em grande parte de sua absorção intacta e, em menor grau, da produção de ácido propiônico, portanto, sendo uma excelente alternativa para o tratamento de casos clínicos de cetose.

Segundo Emery et al. (1964), fornecendo até $2,5 \mathrm{~kg}$ de propileno glicol aproximadamente, relataram alteração na proporção molar de ácido propiônico (30,3\%), em relação ao grupo controle $(19,1 \%)$ e, no laboratório conseguiram a recuperação do propileno glicol, após a incubação in vitro por 24 horas de 65 a $84 \%$, e de apenas 32 a $40 \%$ quando o mesmo processo se deu em 3 horas. Por

Czerkawski \& Breckenfidge (1973), citados por Juchem (2000), estudaram o efeito da dieta sobre a utilização do propileno glicol quando incubado in vitro por 4 horas, observaram que: houve uma utilização de $22 \%$ em dieta contendo feno, $49 \%$ quando incluíram concentrado e $100 \%$ quando incluíram a polpa de beterraba. Os autores sugeriram que a população microbiana predominante pode influenciar na degradação ruminal do propileno glicol.

De acordo com Sauer et al. (1973) trabalhando com níveis de propileno glicol $(0,3,6$, e 9\%) do concentrado nas oito primeiras semanas da lactação, observaram uma redução na incidência de testes positivos para a cetose subclínica no leite $(26,7 ; 17,2 ; 5,6$ e $6,3 \%$, respectivamente). Resultados semelhantes foram também observados com os níveis de AGL sangüíneos, 
menores para os níveis de 6 e $9 \%$, muito embora, o nível de $3 \%$ tenha sido semelhante aos demais em diminuir os níveis plasmáticos de betahidroxibutirato em relação ao controle.

O conhecimento do metabolismo energético de animais no período de transição modificou a orientação das pesquisas. O propileno glicol passou a ser avaliado mais intensamente nos períodos pré e pós-parto, uma vez que, a mobilização do tecido adiposo corporal tem início nas últimas semanas de gestação (Bertics et al., 1992 e Tesfa et al., 1999).

Fornecendo um litro de propileno glicol durante os 10 dias antes do parto, Studer et al. (1993) observaram uma redução significativa nos níveis plasmáticos de beta-hidroxibutirato e AGL (32\%), bem como um aumento nas concentrações de insulina, durante o período de fornecimento. As vacas tratadas com propileno glicol apresentaram também menor concentração de triglicerol hepático do primeiro ao vigésimo primeiro dia de lactação. Não houve diferença significativa para os parâmetros sangüíneos avaliados durante a lactação, embora, os níveis de AGL tivessem mantido o mesmo padrão observado durante o período de fornecimento do propileno glicol. Da mesma forma, Formigoni et al. (1996) avaliaram o fornecimento de $300 \mathrm{~mL}$ de propileno glicol misturado à dieta total, durante o período pré-parto e sob a forma de "Drench", durante os primeiros doze dias da lactação, não tendo observado diferença nos níveis sangüíneos de beta-hidroxibutirato e insulina, já os animais tratados, tiveram concentrações menores de AGL durante o período em que foi administrado sob a forma de "drench."

Fonseca et al. (1997) também forneceram $300 \mathrm{~mL}$ de propileno glicol durante o pré-parto e início de lactação, não tendo observado efeito significativo nas concentrações plasmáticas de beta-hidroxibutirato, AGL e glicose, nem tão pouco efeito sobre a incidência de cetose subclínica e intervalo entre parto e primeiro cio. Entretanto, os autores observaram maior produção de leite na quarta e quinta semanas de lactação para as vacas do tratamento com propileno glicol. Ruegsegger \& Schultz (1986) não encontraram diferenças entre 
as concentrações de glicose, Beta hidróxibutirato e AGL no plasma de vacas tratadas com $125 \mathrm{~mL}$ de propileno glicol.

Grummer et al. (1994) avaliaram a utilização via oral de quatro níveis de propileno glicol (0, 296; 592 e $887 \mathrm{~mL}$ ) aplicados a novilhas Holandesas sob restrição alimentar, de até $50 \%$ do consumo voluntário. A restrição alimentar, mimetizou as alterações de consumo e metabolismo energético, que normalmente ocorrem em vacas nas três semanas que antecedem ao parto. Os autores observaram aumento linear das doses de propileno glicol sobre os níveis plasmáticos de glicose, insulina e, diminuição de beta hidroxibutirato e AGL. A maior resposta por mililitro de propileno glicol ocorreu na dose de 296 $\mathrm{mL}$, embora a maior dose $(887 \mathrm{~mL})$, tenha sido eficiente em gerar valores semelhantes aos encontrados antes da restrição alimentar. Os autores concluíram que, $296 \mathrm{~mL}$ de propileno glicol são quase tão eficientes quanto 887 $\mathrm{mL}$ em reduzir os níveis plasmáticos de AGL para as novilhas que participaram deste experimento.

Fornecendo 2,5 $\mathrm{mL}$ de propileno glicol por quilo de peso metabólico (341 $\mathrm{mL}$ para vacas e $307 \mathrm{~mL}$ para novilhas), Christensen et al. (1997) avaliaram formas de fornecimento (ingestão forçada, no concentrado e na dieta total). A administração forçada ou no concentrado produziram níveis de insulina superiores aos observados com a administração de propileno glicol na dieta total e também foram mais eficientes em reduzir $A G L$ em vacas sob restrição alimentar, porém não encontraram diferenças para beta-hidroxibutirato $\mathrm{e}$ glicose.

De acordo com Birchen et al. (2000), o fornecimento de $228 \mathrm{~mL}$ de propileno glicol sob a forma de "Drench" para vacas Jersey, a partir de uma semana antes do parto até a primeira semana de lactação, provocou aumento na concentração de glicose ao parto, menores concentrações de betahidroxibutirato e menor perda da condição corporal para as vacas tratadas.

Além do uso do propileno glicol, o uso do propionato de cálcio tem despertado um maior interesse devido à presença do mineral poder ajudar na 
diminuição das hipocalcemias. Outras vantagens do uso do propionato seriam o fornecimento de energia prontamente disponível devido às propriedades gliconeogênicas do propionato e causaria um aumento da ingestão de matéria seca, devido a inibição de crescimento de fungos nos alimentos (Schlatter, 1997).

A mobilização de cálcio inicia-se na fase final de gestação (Horst et al., 1994), e continua com o início da produção de leite, quando se requerem grandes quantidades de cálcio sérico. Estas necessidades são supridas através do cálcio da dieta ou derivado do cálcio armazenado nos ossos. A remoção do cálcio dos ossos exige numerosas enzimas, vitaminas $\mathrm{D}$ e um $\mathrm{pH}$ sérico adequado (Horst et al., 1994). Muito embora, as hipocalcemias sejam tratadas com injeções de sais de cálcio, as vacas que sofreram do problema, após a recuperação, são mais susceptíveis a problemas metabólicos e a doenças infecciosas (Curtis et al., 1983; Curtis et al., 1984 e Risco et al., 1984).

Embora, o efeito do cálcio no sangue não seja tão rápido como o do cloreto, a atividade do propionato poderia ser mais sustentada (Goff \& Horst, 1994). O propionato não tem um efeito acidificante no $\mathrm{pH}$ do sangue e, poderia servir como precursor gliconeogênico quando a vaca estiver em balanço negativo de energia (Goff et al., 1996).

A adição de propionato na dieta do ruminante durante o pré-parto tem dois efeitos. Primeiramente, coloca o animal em melhor balanço de energia, e a relação de VLD/NEFA irá favorecer o metabolismo dos ácidos graxos hepáticos e segundo, o metabolismo de ácidos graxos para acetil-CoA é balanceado pelo efeito gliconeogênico do propionato. Este efeito gliconeogênico do propionato ocorre, porque o propionato no fígado é metabolizado para oxaloacetato. Este produto pode ser utilizado diretamente para balancear a produção de acetil-CoA da beta oxidadação da gordura no ciclo de Krebs, mas a maioria desse novo oxaloacetato, entretanto, é utilizado para gerar nova glicose através do processo reverso da glicólise e, esta nova glicose pode ajudar na diminuição da cetose e maior produção de leite (Schlatter, 1997). 
Rufino et al. (1997) administraram $114 \mathrm{~g} /$ dia de propionato de cálcio via oral e, observaram aumento na produção de leite, insulina e glicose plasmática, porém, não observaram alteração nos ácidos graxos voláteis (AGV) encontrados no rúmen, que são provenientes quase que em sua totalidade, da fermentação dos carboidratos dietéticos, e constituem a maior fonte de energia para os ruminantes. A concentração total de AGV no rúmen, e a respectiva quantidade de cada um depende tanto da composição da ração, nível de consumo e manejo alimentar. Dietas ricas em amido e sacarose favorecem a formação do ácido propiônico, um precursor de glicose, cuja síntese é feita por dois mecanismos; o primeiro envolve a formação de oxaloacetato e succinato e o segundo envolve a formação do acrilato.

Don Aslup \& Schlatter (1997) também usando o mesmo produto na ração total, quando ofereceram $114 \mathrm{~g}$ por animal, durante 14 dias, para 700 vacas, encontraram diminuição dos corpos cetônicos, deslocamento de abomaso, retenção de placenta e aumento de hipocalcemia e pico de produção. Da mesma forma, Olson \& Schlatter (1997) encontraram redução de 19\% para 14\% de desordens metabólicas, quando forneceram $114 \mathrm{~g}$ de propionato de cálcio para vacas em transição. Welser \& Schlatter (1997) também forneceram $114 \mathrm{~g}$ de propionato de cálcio por animal, iniciando 3 dias antes do parto até 9 dias pós-parto, e encontraram uma redução de $7 \%$ de cetose, $11 \%$ de hipocalcemia, $2 \%$ de deslocamento de abomaso e $6 \%$ de múltiplos sintomas clínicos. 


\section{MATERIAL E MÉTODOS}

\subsection{Local}

O presente projeto foi realizado em duas Fazendas comerciais, ambas com criação de gado Holandês, localizadas nos municípios de Araras (Fazenda 1) e Engenheiro Coelho (Fazenda 2), Estado de São Paulo.

\subsection{Animais}

Foram utilizados 165 animais, sendo 132 vacas e 33 novilhas Holandesas P.O e P.C, que tiveram suas parições entre 15 de março a 15 de junho de 1999. A Fazenda 1 contribuiu com 96 vacas e 26 novilhas e a Fazenda 2 com 36 vacas e 7 novilhas. As colheitas de dados iniciaram em 15 de março e se estenderam até 12 de agosto de 1999, totalizando um período de 150 dias de experimento. os animais foram manejados em sistema de confinamento tipo "free-stall" e com programa de alimentação com dieta total. Os animais do experimento não foram separados dos demais e foi seguido o mesmo sistema de manejo de cada propriedade.

\subsection{Tratamentos}

Os tratamentos experimentais foram os seguintes:

A) Tratamento 1- Controle (C), este grupo foi composto de 41 animais (31 vacas e 10 novilhas) submetidos às mesmas condições de manejo aplicados 
aos demais tratamentos. Das 31 vacas, vinte e três eram da Fazenda 1 e oito da Fazenda 2. Das 10 novilhas, oito eram provenientes da Fazenda $1 \mathrm{e}$ duas da Fazenda 2.

B) Tratamento 2- Drench (DR), administração via oral de "Dairy Power Drench ${ }^{\circledR}$ ", em 42 animais, (31 vacas e 11 novilhas), que receberam os tratamentos conforme as recomendações do fabricante, ou seja, 3 aplicações, sendo a primeira no dia do parto e por mais dois dias consecutivos. Das 31 vacas, vinte e três eram provenientes da Fazenda $1 \mathrm{e}$ oito da Fazenda 2. Das 11 novilhas, nove eram da Fazenda 1 e duas da Fazenda 2. O produto, comercializado em embalagens de $500 \mathrm{~g}$, era diluído em 25 a 30 litros de água morna e administrado via oral através de uma sonda. A composição do Dairy Power Drench ${ }^{\circledR}$, de acordo com o fabricante é a seguinte: levedura (Yea-Sacc), carbonato de cálcio, bicarbonato de sódio, cloreto de potássio, sulfato de cobalto, sulfato de magnésio, cromo quelatado, vitaminas do complexo $\mathrm{B}$, propileno glicol, dextrose $\mathrm{e}$ flavorizantes.

C) Tratamento 3- Propileno glicol (PG), administração diária de $500 \mathrm{~mL}$ de propileno glicol oralmente em 43 animais (33 vacas e 10 novilhas), iniciando em média treze dias antes da data provável do parto até 49 dias pós-parto. Das 33 vacas, a Fazenda 1 contribuiu com vinte e três, e a Fazenda 2 com dez. Das 10 novilhas, oito eram provenientes da Fazenda 1 e duas da Fazenda 2. O propileno glicol foi administrado aos animais via oral $(500 \mathrm{~mL}$ por dia), sempre pela manhã.

D) Tratamento 4- Propionato de cálcio (PC), administração, diária de $500 \mathrm{~g}$ de propionato de cálcio via oral, em 39 animais (37 vacas e 2 novilhas), sendo o tratamento iniciado em média onze dias antes da data provável do parto até 51 dias pós-parto. Das 37 vacas, 27 eram da Fazenda 1 e dez da Fazenda 2. E das 2 novilhas, cada fazenda contribuiu com uma. O propionato foi adquirido em embalagens de sacos plásticos, que continham $20 \mathrm{~kg}$ na forma de pó. O produto foi colocado em garrafas de vidros de um 
litro e completado ao foi adicionado volume de água suficiente para um litro, após homogeneização por agitação, a solução era fornecida aos animais, nos mesmos horários do grupo anterior. OBS.: Neste grupo duas novilhas morreram e uma vaca apresentou problema respiratório devido a ingestão por falsa via.

\subsection{Variáveis avaliadas}

\subsubsection{Escore de condição corporal}

O escore de condição corporal (ECC), foi avaliado semanalmente, segundo a metodologia de Wildman et al. (1982). O qual usa uma escala de $1 \mathrm{a}$ 5 , onde 1 (magra) e 5 (gorda), sendo utilizados intervalos de 0,25 pontos.

A variação do escore corporal foi obtida da diferença entre o ECC da semana 6 e da semana 1 para cada animal.

\subsubsection{Peso corporal}

Foi realizada a aferição do peso corporal dos animais com auxílio da fita barimétrica, no mesmo dia da avaliação da condição corporal. Este procedimento foi realizado sempre pela mesma pessoa, para evitar a possibilidade de interferência do avaliador.

A variação do peso corporal foi obtida da diferença entre o peso na $6^{a}$ semana e na $1^{\text {a }}$ semana experimental para cada animal.

A variação diária do peso corporal corresponde à perda diária de peso durante o período experimental. 


\subsubsection{Produção de leite}

Os animais foram ordenhados 3 vezes ao dia e a produção de leite foi medida individualmente uma vez por semana em todos os animais.

\subsubsection{Parâmetro sangüíneo}

As amostras sangüíneas foram colhidas uma vez por semana em tubos "vacuntainer" com oxalato de potássio e fluoreto de sódio, para a determinação dos ácidos graxos livres. Amostras em duplicata foram colocadas em caixa isotérmica até chegar ao local de centrifugação, que demorava aproximadamente 3 horas e então foram centrifugadas a $3000 \mathrm{xg}$, durante 20 minutos. O plasma foi colocado em tubos "eppendorf", em duplicata e armazenados em "freezer" a $-20^{\circ} \mathrm{C}$ para posterior análise. As análises de ácidos graxos livres foram realizadas com o uso do KIT NEFA C (WAKO Chemicals, Code no. 994-75409E). Este teste se baseia no método enzimático colorimétrico adaptado para ser usado em placas de microtítulo e posterior leitura em aparelho tipo "Elisa Reader", com filtro de 550nm e apresenta os resultados em micromolar por litro.

\subsubsection{Parâmetros reprodutivos}

Foram avaliados o número de dias para o aparecimento do primeiro cio pós-parto, período de serviço e número de serviços por concepção.

\subsubsection{Amostragem do alimento}

As amostras de ração completa foram colhidas mensalmente e a cada duas colheitas, retirou-se uma amostra a qual foi armazenada a $-18^{0} \mathrm{C}$ para posterior análise bromatológica, a qual foi realizada no laboratório de análise 
bromatológica da AGRIBANDS, análises de MS, PB, EE, FB, MM, Ca e P foram analisados segundo AOAC (1985), FDN e FDA segundo Van Soest et al. (1991). A composição bromatológica das dietas está apresentada na Tabela 1.

Tabela 1. Composição bromatológica das dietas das vacas em lactação das Fazendas 1 e 2, com base na matéria seca.

\begin{tabular}{lcc}
\hline Composição & Fazenda 1 & Fazenda 2 \\
\hline MS (\%) & 51,65 & 44,45 \\
PB (\%) & 16,96 & 17,08 \\
EE (\%) & 4,76 & 4,58 \\
FB (\%) & 17,65 & 17,13 \\
FDA (\%) & 20,89 & 21,0 \\
FDN (\%) & 36,34 & 39,1 \\
MM (\%) & 6,0 & 6,63 \\
Ca (\%) & 0,9 & 0,81 \\
P (\%) & 0,32 & 0,29 \\
ENN (\%) & 54,65 & 54,59 \\
NDT (\%) & 71,71 & 71,33 \\
\hline
\end{tabular}

$\mathrm{MS}=$ matéria seca; $\mathrm{PB}=$ proteína bruta, $\mathrm{EE}=$ =xtrato etéreo; $\mathrm{FB}=$ fibra bruta; $\mathrm{FDA}$ =fibra em detergente ácido; $\mathrm{FDN}=$ fibra em detergente neutro; $\mathrm{MM}=$ =matéria mineral; $\mathrm{Ca}=$ =álcio; $\mathrm{P}=$ fósforo; $\mathrm{ENN}=$ extrativo não nitrogenado; NDT=nutrientes digestíveis totais.

\subsection{Análise estatística}

Os dados obtidos foram analisados através do programa computacional Statistical Analysis System (SAS Institute Inc., 1985), sendo anteriormente verificada a normalidade dos resíduos pelo Teste de Shapiro-Wilk (PROC UNIVARIATE) e as variâncias comparadas pelo Teste de Hartley (Ott, 1983). Os dados que não atenderam a estas premissas foram submetidos à transformação logarítmica $[\log (X+1)]$ ou pela raiz quadrada $[R Q(X+1 / 2)]$. Os dados originais ou transformados, quando este último procedimento foi necessário, foram submetidos à análise de variância que separou como causas de variação efeito de tratamento e efeito dos blocos formados em função da fazenda (Fazenda 1 e 2) e do números de partos (primíparas ou multíparas). 
As análises referentes aos valores de produção de leite, escore de condição corporal, peso vivo, variação diária do peso corporal dos animais e ácidos graxos livres foram analisados conforme descrito anteriormente, porém, foram acrescidos do fator medidas repetidas no tempo, referentes aos diversos momentos de colheita dos dados semanais (Tabela 2). As probabilidades das interações com o tempo foram determinadas pelo teste de Greenhouse-Geisse, utilizando-se o comando "REPEATED" gerado pelo procedimento GLM (PROC GLM do SAS). As análises por tempo somente foram realizadas quando as interações entre tempo e tratamentos foram significativas. A avaliação do efeito tempo dentro de cada tratamento foi realizada através de regressão, onde utilizou-se contrastes polinomiais. Na presença de efeito linear ou quadrático foi obtida a respectiva equação de regressão e o coeficiente de determinação $\left(R^{2}\right)$.

$\mathrm{Na}$ presença de efeito de tratamento, a comparação entre as médias dos tratamentos foi realizada através do teste de Tukey. Utilizou-se um nível de significância de $5 \%$ para todos os testes realizados, exceto quando especificado.

Tabela 2. Esquema da análise de variância em delineamento em blocos casualizados com 6 medidas repetidas no tempo.

\begin{tabular}{lc}
\hline Causas de variação & Graus de Liberdade \\
\hline Tratamentos & 3 \\
Número de lactações & 1 \\
Fazenda & 1 \\
Resíduo A & 154 \\
Sub-parcelas & $\mathbf{1 5 9}$ \\
Tempos & 5 \\
Interação Tempo x Tratamento & 15 \\
Interação Tempo x Lactações & 5 \\
Interação Tempo x Fazenda & 5 \\
Resíduo B & $\mathbf{7 7 0}$ \\
\hline
\end{tabular}




\section{RESULTADOS E DISCUSSÃO}

\subsection{Condição corporal}

\subsubsection{Escore de condição corporal (ECC)}

Para a variável escore de condição corporal não foi observada interação entre tratamento e tempo. Entretanto, houve uma tendência $(P=0,0752)$ de efeito de tratamento sobre o escore de condição corporal e efeito significativo de tempo $(P=0,0001)$, observando-se ser este de comportamento quadrático $(P=0,0001)$. Estes efeitos encontram-se nas Tabelas 4 e 5 e Figura 1.

Durante todo o período experimental, as vacas que receberam "Drench" tenderam a apresentar uma condição corporal $6 \%$ superior somente em relação ao grupo que recebeu propileno glicol (Tabela 3 ).

Apesar de não ter sido observada interação entre tempo e tratamento, durante as 3 primeiras semanas de experimento, não houve diferença no ECC $(P=0,1281)$ entre os tratamentos. Já na quarta semana, houve uma tendência $(P=0,0719)$ do $E C C$ das vacas tratadas com o "Drench" ser maior quando comparado com o grupo de vacas tratadas com propileno glicol. Este efeito passou a ser significativo ( $P=0,0097)$ na quinta semana, sendo que, na sexta semana obteve-se novamente uma tendência $(P=0,0751)$ do $E C C$ ser maior para o grupo "Drench" comparado com o propileno glicol.

Estes resultados estão de acordo com os encontrados por Domeq et al. (1997), os quais relataram perdas de 0,37 unidades de condição corporal entre a primeira e quarta semana de lactação em um estudo realizado com 720 vacas 
em dois rebanhos comerciais sem adição de suplementos energéticos. Da mesma forma, Mashek \& Beede (2000) observaram perda de 0,13 e 0,27 ECC, para as vacas entre a terceira e sexta semana pós-parto que tiveram tratamento com dieta rica em energia e vacas tratadas com baixo nível de energia, respectivamente. Os autores testaram a hipótese de que as vacas recebendo uma dieta de alta energia por um período longo poderiam melhorar o "status" energético no início da lactação e, pelos resultados, observaram uma menor perda da condição corporal neste grupo de animais.

Durante as 6 semanas do experimento, o ECC para o grupo de vacas tratadas com propileno glicol foi 3,0. Este resultado apresenta-se semelhante ao encontrado por Fonseca (1997) de 3,11, tendo este utilizado apenas 15 doses de $300 \mathrm{~mL}$ de propileno glicol, com administração diária (do quarto dia pré-parto até o parto) e em dias alternados (do $10^{\circ}$ ao sexto dia pré-parto e do parto até $\circ 16^{\circ}$ dia pós-parto). Studer (1993) também encontrou resultados semelhantes (ECC de 3,1), ao do presente experimento para as vacas que receberam $1 \mathrm{~L}$ de $\mathrm{PG}$, diariamente, durante 7 dias anteriores à data provável do parto. Da mesma forma, Juchem (2000) forneceu $300 \mathrm{~mL}$ diários e os animais apresentaram ECC de 3,13 na sexta semana de lactação. Porém, seus animais apresentaram produções de leite maiores $(31,18 \mathrm{~kg})$ que os animais do presente experimento. Talvez o uso de menor quantidade de propileno glicol possa causar o mesmo efeito gliconeogênico, conforme resultados obtidos por Grummer et al. (1994) ou doses maiores de PG possam diminuir a ingestão de matéria seca, conforme citação de Fisher et al. (1973) e Christensen et al. (1997).

Embora os dados de ECC sejam diferentes nos diferentes experimentos, Gearhart et al. (1990) define como condição corporal ideal para vacas em cada estágio de lactação, sendo aquela que otimiza a produção de leite, minimiza os problemas de saúde e desordens reprodutivas e maximiza o retorno econômico dos animais. Para Grummer (1994), o manejo ideal para a vaca no período de transição é que o parto ocorra em boa condição corporal, diminua a incidência 
de fígado gorduroso, maximize a ingestão de matéria seca (MS), que o BEN não seja acentuado e que as funções e eficiências reprodutivas não sejam diminuídas. Devemos ressaltar que Gearhart et al. (1990) afirmaram que a utilização de energia metabolizável para ganho de peso é maior para as vacas em lactação do que no período seco e que o período seco pode ser muito curto para as vacas recuperarem a perda de condição corporal.

Loeffler et al. (1999) encontraram forte correlação entre a incidência de febre do leite e perda de condição corporal. Também observaram que o ECC médio de todos os tratamentos na primeira semana foi de 3,31 , enquanto que ao final do experimento (sexta semana) foi de 3,04, apresentando um efeito quadrático.

Dell'Orto et al. (2000) observaram que a condição corporal aos 15 dias pós-parto tendeu ser maior nas vacas tratadas com uma mistura de propileno glicol, dextrose e probióticos, quando comparada com o grupo controle (3,43 vs. 3,25 respectivamente), enquanto no período seco a média do ECC foi de 3,7 e não houve diferença entre os grupos. Esta média foi superior às encontradas no presente experimento.

No início da lactação, vacas leiteiras de raças especializadas, não mantêm um balanço energético positivo devido a alta produção e a capacidade limitada de ingestão de alimentos, portanto disponibilizam as reservas corporais através da lipólise, acarretando diminuição da condição corporal e ou do peso (Otto, 1991). As vacas que chegam ao parto com excessiva condição corporal, geralmente perdem mais peso durante o início da lactação e pode ter influência negativa na reprodução e produção de leite (Garnsworthy, 1988).

No presente experimento, provavelmente não deve ter ocorrido alta taxa de lipólise, pois a variação da condição corporal foi pequena. Snijders et al. (2001) encontraram uma variação do ECC de 0,47 entre o parto e $\circ 72^{\circ}$ dia e 0,23 entre o parto e $\circ 70^{\circ}$ dia, para vacas de alto e médio mérito genético para produção de leite, respectivamente, embora estes autores não tenham administrado suplementos energéticos. Os autores observaram também que a 
condição corporal influenciou a qualidade dos embriões, pois os embriões oriundos de vacas com baixo ECC apresentavam menores taxas de clivagem e menores taxas de desenvolvimento do que as vacas em melhor condição corporal.

Tabela 3. Efeitos dos tratamentos sobre o escore de condição corporal durante o período experimental.

\begin{tabular}{|c|c|c|c|c|c|c|c|}
\hline \multirow[b]{2}{*}{ Semana } & \multicolumn{4}{|c|}{ Tratamentos } & \multirow[b]{2}{*}{ Média } & \multirow[b]{2}{*}{ EPM } & \multirow[b]{2}{*}{$P$} \\
\hline & C & DR & PC & $P G$ & & & \\
\hline 1 & 3,3 & 3,4 & 3,3 & 3,2 & 3,3 & 0,029 & 0,2886 \\
\hline 2 & 3,2 & 3,3 & 3,2 & 3,1 & 3,2 & 0,027 & 0,2676 \\
\hline 3 & 3,1 & 3,2 & 3,2 & 3,0 & 3,1 & 0,027 & 0,1281 \\
\hline 4 & $3,1_{a b}$ & $3,2_{a}$ & $3,1_{\mathrm{ab}}$ & $3,0_{b}$ & 3,1 & 0,027 & 0,0719 \\
\hline 5 & $3,0^{A B}{ }_{b}$ & $3,2^{A}{ }_{a}$ & $3,1^{\mathrm{AB}}{ }_{\mathrm{ab}}$ & $3,0^{\mathrm{B}} \mathrm{b}$ & 3,1 & 0,024 & 0,0097 \\
\hline 6 & $3,0_{a b}$ & $3,1_{a}$ & $3,1_{\mathrm{ab}}$ & $3,0_{b}$ & 3,0 & 0,024 & 0,0751 \\
\hline Média & $3,1^{A}{ }_{a b}$ & $3,2^{A}{ }_{a}$ & $3,2^{A}{ }_{a b}$ & $3,0^{A}{ }_{b}$ & 3,1 & 0,011 & 0,0752 \\
\hline
\end{tabular}

$\mathrm{C}=$ controle; $\mathrm{DR}=$ "drench"; $\mathrm{PC}=$ propionato de cálcio; $\mathrm{PG}=$ propileno glicol; $\mathrm{EPM}=$ erro padrão da média; $\mathrm{P}=$ probabilidade estatística.

Letras diferentes sobrescritas dentro de cada linha diferem estatisticamente pelo teste de Tukey a $5 \%$ e subescritas a $10 \%$.

Tabela 4. Probabilidades estatísticas dos efeitos de tratamento e tempo e sua interação sobre o escore de condição corporal.

\begin{tabular}{lc}
\hline \multicolumn{1}{c}{ Efeito } & $\mathbf{P}$ \\
\hline Tratamentos & 0,0752 \\
Tempo & 0,0001 \\
$\quad$ Linear & 0,0001 \\
Quadrático & 0,0001 \\
Tratamento x Tempo & 0,7754 \\
\hline
\end{tabular}


Tabela 5. Equações de regressão para efeito de tempo dentro de cada tratamento, sobre o escore de condição corporal, coeficiente de determinação $\left(R^{2}\right)$ e probabilidade.

\begin{tabular}{llccc}
\hline & \multicolumn{1}{c}{} & & \\
\multicolumn{1}{c}{ Trat } & \multicolumn{1}{c}{ Equação } & $\mathbf{R}^{\mathbf{2}}$ & $\mathbf{L}$ & $\mathbf{Q}$ \\
\hline C & ECC $=3,321-0,0576 \mathrm{sem}$ & 0,0759 & 0,0001 & 0,2652 \\
DR & ECC $=3,379-0,0461 \mathrm{sem}$ & 0,0623 & 0,0002 & 0,1750 \\
PC & ECC $=3,359-0,0530 \mathrm{sem}$ & 0,0845 & 0,0001 & 0,2887 \\
PG & ECC $=3,242-0,0555 \mathrm{sem}$ & 0,0888 & 0,0001 & 0,0579 \\
Total & ECC $=\mathbf{3 , 4 3 3 - 0 , 1 3 5} \mathbf{~ s e m}+\mathbf{0 , 0 1 1 8} \mathbf{s e m}^{2}$ & $\mathbf{0 , 0 7 3 0}$ & $\mathbf{0 , 0 0 0 1}$ & $\mathbf{0 , 0 0 0 1}$ \\
\hline
\end{tabular}

Trat.=tratamentos; C=controle; $\mathrm{DR}=$ "drench"; $\mathrm{PC}=$ propionato de cálcio; $\mathrm{PG}=$ propileno glicol; $\mathrm{R}^{2}=$ coeficiente de determinação; $\mathrm{P}=$ probabilidade; $\mathrm{L}=$ efeito linear; $\mathrm{Q}=$ efeito

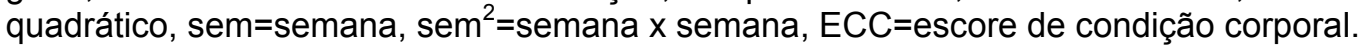

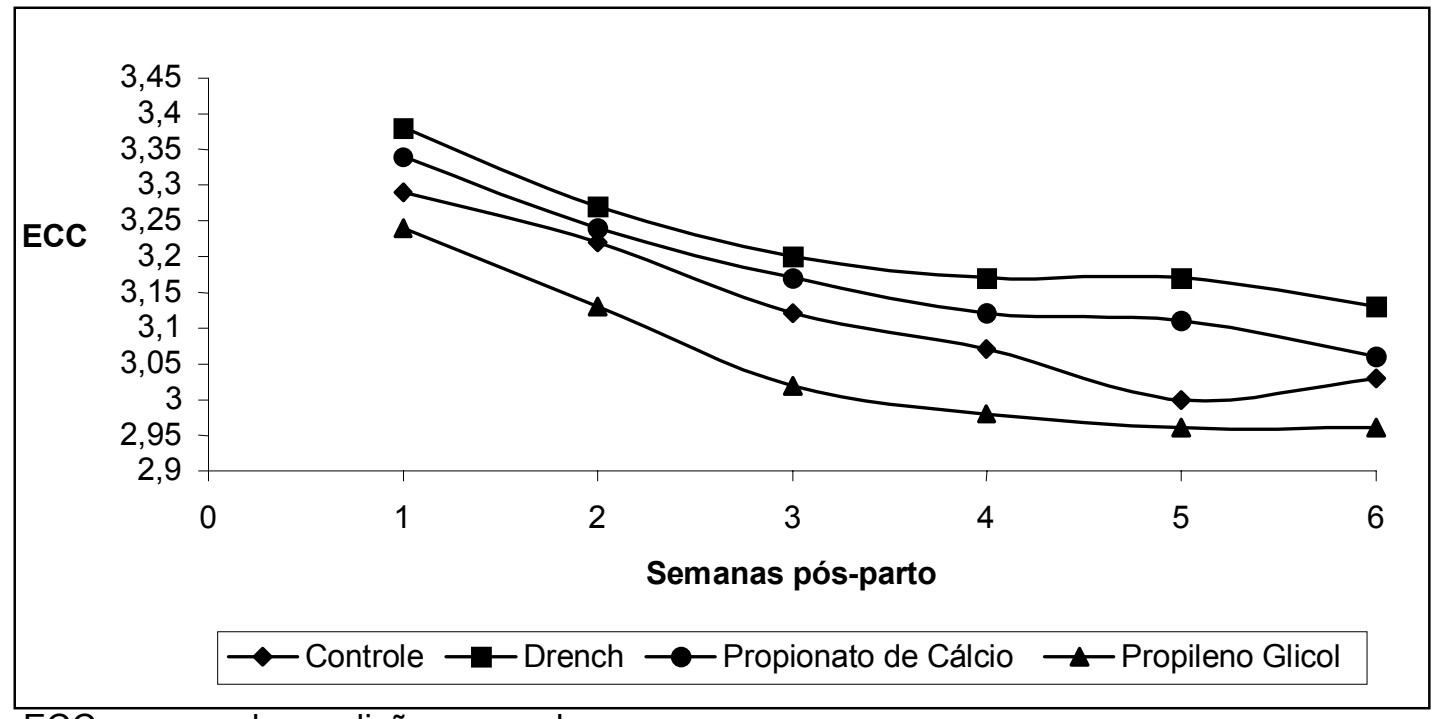

$\mathrm{ECC}=$ escore de condição corporal

Figura 1- Efeitos dos tratamentos sobre o escore de condição corporal durante o período experimental. 


\subsubsection{Variação no escore de condição corporal}

Não houve diferença ( $P=0,7774)$ na variação da condição corporal entre os tratamentos durante o período experimental (Tabela 6). Em média, as vacas perderam 0,28 pontos no escore corporal. Portanto, considerando que uma unidade de perda representa uma redução de $84 \mathrm{~kg}$ de peso vivo (NRC, 2001), as vacas nos 49 dias de experimento após o parto perderam aproximadamente $23,5 \mathrm{~kg}$.

Tabela 6. Diferença de ECC $\left(E_{C C}-E_{6} C_{1}\right)$ das vacas durante o período experimental

\begin{tabular}{|c|c|c|c|c|c|c|c|}
\hline & \multicolumn{4}{|c|}{ Tratamentos } & \multirow{2}{*}{ Média } & \multirow{2}{*}{ EPM } & \multirow{2}{*}{$P$} \\
\hline & C & DR & PC & PG & & & \\
\hline Variação & $-0,26$ & $-0,26$ & $-0,30$ & $-0,30$ & $-0,28$ & 0,0207 & 0,7774 \\
\hline
\end{tabular}

O ECC para as vacas tratadas com o propionato de cálcio deste experimento foi de 3,2 no final do experimento, portanto uma queda de 0,30 unidades quando comparado com a semana inicial, enquanto que Don Aslup \& Schlatter (1997) obtiveram queda de 0,22, apesar destes autores terem utilizado apenas $114 \mathrm{~g}$ do mesmo produto.

Moallen et al. (1997) observaram uma perda de 0,68 de ECC no grupo controle, porém neste experimento ocorreu uma perda de 0,26 para o mesmo grupo. Buckley et al. (2000) observaram maior perda de condição corporal para os animais de alto mérito genético para produção de leite, sendo que este grupo perdeu em média $0,13 \mathrm{~kg} /$ dia nas 8 primeiras semanas, enquanto as vacas de médio mérito genético perderam em média apenas $0,08 \mathrm{~kg} / \mathrm{dia}$ no mesmo período. Heuwieser et al. (1994) também encontraram perdas de ECC iguais a $0,46,0,68,0,44$ e 0,52 para quatro diferentes propriedades. Da mesma forma, Jorritsma et al. (2000) encontraram perdas de 0,5 e 0,7 unidades de 
escore corporal quando avaliaram animais com concentrações de triglicerol menores de $50 \mathrm{mg} / \mathrm{g}$ e maiores de $50 \mathrm{mg} / \mathrm{g}$, respectivamente.

Talvez o fato dos animais deste experimento não terem apresentado ECC muito alto ao parto pode ter contribuído para uma menor variação do mesmo e menor diminuição no consumo de matéria seca no período transicional, podendo ser atribuído ao bom manejo nutricional das propriedades. Outra hipótese seria que os animais não eram de altíssima produção (23 kg na primeira semana), não havendo assim necessidade de utilização de grandes quantidades de reservas corporais e consequentemente menor variação na condição corporal.

\subsection{Peso dos animais}

\subsubsection{Peso corporal (PC)}

Não houve diferença $(P=0,8698)$ na perda de peso dos animais entre os tratamentos (Tabela 7 e Figura 2). Da mesma forma, não foi observado efeito de interação tempo e tratamento $(\mathrm{P}=0,8223)$ (Tabela 8). Entretanto, o peso corporal sofreu um efeito quadrático no tempo $(P=0,0001)$, estando esta equação apresentada na Tabela 9. 
Tabela 7. Efeitos dos tratamentos sobre o peso e variação do peso corporal dos animais $(\mathrm{kg})$ durante o período experimental.

\begin{tabular}{cccccccc}
\hline \multicolumn{7}{c}{ Tratamentos } \\
Semana & C & DR & PC & PG & Média & EPM & P \\
\hline 1 & 554,6 & 555,0 & 563,9 & 559,5 & 558,2 & 5,338 & 0,7567 \\
2 & 546,0 & 545,1 & 553,2 & 543,5 & 546,8 & 5,418 & 0,7374 \\
3 & 535,3 & 537,4 & 545,5 & 537,8 & 538,9 & 5,476 & 0,7282 \\
4 & 528,0 & 533,8 & 543,1 & 528,4 & 533,2 & 5,428 & 0,7893 \\
5 & 524,8 & 524,9 & 540,3 & 530,7 & 530,0 & 5,413 & 0,9353 \\
6 & 527,0 & 527,9 & 537,2 & 529,3 & 530,2 & 5,295 & 0,7924 \\
Média & $\mathbf{5 3 6 , 0}$ & $\mathbf{5 3 7 , 3}$ & $\mathbf{5 4 7 , 2}$ & $\mathbf{5 3 8 , 3}$ & $\mathbf{5 3 9 , 6}$ & $\mathbf{2 , 2 2 1}$ & $\mathbf{0 , 8 6 9 8}$ \\
Variação & $-31,2$ & $-27,1$ & $-29,1$ & $-30,7$ & $-29,5$ & 2,141 & 0,9048 \\
\hline
\end{tabular}

$\mathrm{C}=$ controle; $\mathrm{DR}=$ "drench"; $\mathrm{PC}=$ propionato de cálcio; $\mathrm{PG}=$ propileno glicol; $\mathrm{EPM=erro} \mathrm{padrão}$ da média; $P=$ probabilidade estatística.

Variação=diferença entre o peso na semana 6 e na semana 1

Tabela 8. Probabilidades estatísticas dos efeitos de tratamento e tempo e sua interação sobre o peso corporal.

\begin{tabular}{lc}
\hline \multicolumn{1}{c}{ Efeito } & $\mathbf{P}$ \\
\hline Tratamentos & 0,8698 \\
Tempo & 0,0001 \\
$\quad$ Linear & 0,0001 \\
Quadrático & 0,0001 \\
Tratamento x Tempo & 0,8223 \\
\hline
\end{tabular}

Tabela 9. Equações de regressão para efeito tempo, dentro de cada tratamento sobre o peso corporal $(\mathrm{kg})$, coeficientes de determinação e probabilidades.

\begin{tabular}{|c|c|c|c|c|}
\hline \multirow[b]{2}{*}{ Trat } & \multirow[b]{2}{*}{ Equação } & \multirow[b]{2}{*}{$\mathbf{R}^{\mathbf{2}}$} & \multicolumn{2}{|c|}{$\mathbf{P}$} \\
\hline & & & $\mathbf{L}$ & $\mathbf{Q}$ \\
\hline C & Peso $=556,851-5,977 \mathrm{sem}$ & 0,0239 & 0,0253 & 0,4086 \\
\hline DR & Peso $=557,335-5,710 \mathrm{sem}$ & 0,0156 & 0,0616 & 0,6078 \\
\hline PC & Peso $=564,698-5,003 \mathrm{sem}$ & 0,0276 & 0,0169 & 0,4694 \\
\hline$P G$ & Peso=558,124-5,699 sem & 0,0259 & 0,0229 & 0,2716 \\
\hline Total & Peso $=571,952-15,207 \mathrm{sem}+1,3729 \mathrm{sem}^{2}$ & 0,0212 & 0,0001 & 0,0001 \\
\hline
\end{tabular}

Trat.=tratamentos; C=controle; $\mathrm{DR=}$ =drench"; PC=propionato de cálcio; PG=propileno glicol; $\mathrm{R}^{2}=$ coeficiente de determinação; $\mathrm{P}=$ probabilidade; $\mathrm{L}=$ efeito linear; $\mathrm{Q}=$ efeito quadrático, sem=semana; sem $^{2}=$ semana $x$ semana 


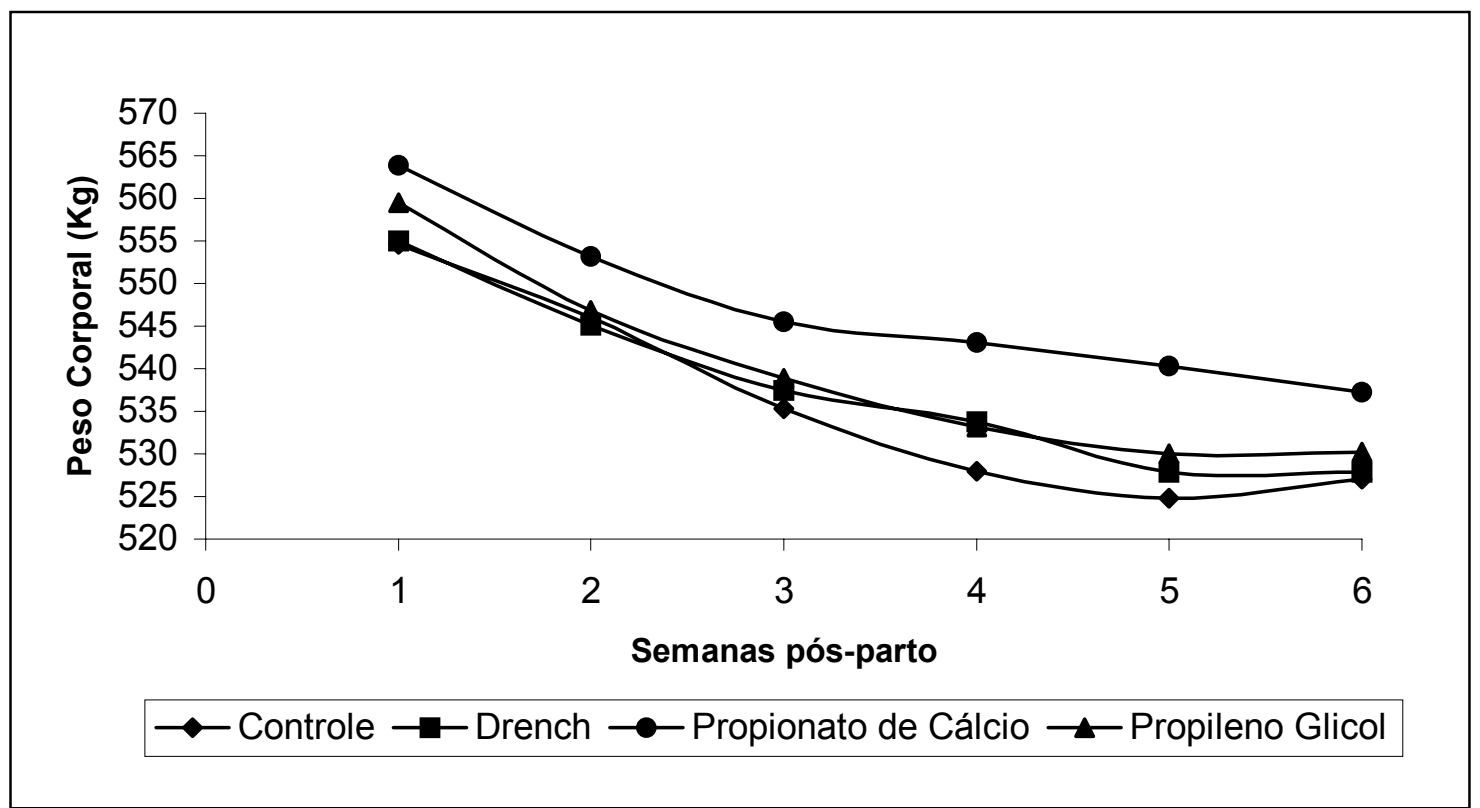

Figura 2- Efeitos dos tratamentos sobre o peso corporal durante o período experimental.

O peso médio das vacas durante o período experimental, considerando todos os tratamentos, foi de 539,6 kg (558,2 no início e 530,2 kg no final). Estes resultados com relação à perda de peso estão de acordo com Butler et al. (1989) que afirmaram que no início da lactação a energia derivada do consumo dos alimentos é menor do que as exigências para mantença e produção. Esta é a razão pela qual vacas com alta produção de leite utilizam as reservas corporais para suprir tais deficiências, resultando em perdas de peso e condição corporal. Maior perda também se observa em vacas obesas ao parto, desta forma, Rukkwamsuk et al. (1998) observaram que durante o período seco, o ganho médio tendeu a ser maior em vacas com excesso de peso (supercondicionadas) do que em vacas com restrição alimentar (82,4 vs. 54,7 $\mathrm{kg})$. Entretanto, até a quarta semana após o parto, a perda média de peso vivo foi maior $(175 \%)$ para as vacas com excesso de peso quando comparado com as vacas em restrição alimentar ( $88 \mathrm{vs.} 32 \mathrm{~kg}$ ). Esta perda foi bem superior à observada no presente experimento que foi de $29,5 \mathrm{~kg}$, pois as vacas não 
estavam obesas antes do parto e a produção de leite $(23 \mathrm{~kg})$ na primeira semana pós-parto não foi muito alta (Tabela 13).

Os resultados de Zurek et al. (1995) mostraram que as vacas perderam $56 \mathrm{~kg}$ de peso do parto até 24 dias em lactação, sendo superior a perda de 19,3 $\mathrm{kg}$ observada neste protocolo experimental no mesmo período pós-parto. Resultados próximos foram encontrados por Van Saun et al. (1993) onde as vacas perderam $17 \mathrm{~kg}$, quando receberam dietas de alta degradabilidade de proteína no pré-parto e 12,2 kg para as vacas que receberam dietas com baixa degradabilidade protéica, em vacas com peso médio de $518 \mathrm{~kg}$, próximos aos $539,6 \mathrm{~kg}$ do presente experimento, onde as vacas receberam teores de proteína degradável de acordo com as recomendações do NRC (1989). Rukkwamsuk et al. (2000) observaram que as vacas sob restrição alimentar no período seco ganharam 67,8 kg e perderam 16,3 kg nas cinco primeiras semanas de lactação. Este resultado se apresenta inferior ao encontrado no presente experimento, que foi de $28,2 \mathrm{~kg}$ no mesmo período.

As vacas obesas mobilizam mais reservas corporais no pós-parto pois sofrem um balanço energético negativo mais severo (Rukkwamsuk et al., 1999). Em outro experimento, Holcomb et al. (2001) obtiveram perdas de peso no pós-parto de $38 \mathrm{~kg}$ nos animais que durante o pré-parto se alimentaram de dietas com baixa forragem de maneira restrita, sendo assim quase $100 \%$ acima dos valores médios observados neste experimento, muito embora com dietas diferentes.

\subsubsection{Variação diária do peso corporal}

Em média, as vacas perderam $0,79 \mathrm{~kg} /$ dia durante todo o período experimental (Tabela 10 e Figura 3). Para esta variável, não foi observada interação entre tempo e tratamento $(P=0,6252)$, nem tampouco efeito de tratamento $(P=0,6684)$. Entretanto, observou-se efeito do tempo $(P=0,0001)$ 
sobre esta variável, apresentando um comportamento quadrático $(P=0,0375)$ (Tabela 11), estando esta equação apresentada na Tabela 12.

$\mathrm{Na}$ primeira semana, as vacas perderam em média $1,54 \mathrm{~kg} / \mathrm{dia}$. Nas semanas subsequentes, as perdas médias foram de 1,23, 0,82, 0,57, 0,13 e $0,43 \mathrm{~kg} /$ dia para as semanas $2,3,4,5$ e 6 , respectivamente.

Buckley et al. (2000) observaram que as vacas de alto $(28,2 \mathrm{~kg})$ e as de médio $(25,0 \mathrm{~kg})$ mérito genético para produção de leite tiveram perda de peso de 0,80 e $0,65 \mathrm{~kg} / \mathrm{dia}$, da primeira à quarta semana de lactação, respectivamente, o que corresponde a aproximadamente $22,4 \mathrm{~kg}$ para o primeiro grupo e $18,2 \mathrm{~kg}$ para o segundo, valores estes bem próximos aos do presente experimento. Por outro lado, Zurek et al. (1995) observaram uma perda de peso de 2,8 kg/dia e 2,2 kg/dia para as vacas que ovularam antes e após 24 dias pós-parto, equivalente a perdas de $67,2 \mathrm{~kg}$ e $52,8 \mathrm{~kg}$, respectivamente, valores bem superiores aos do presente experimento, provavelmente devido a maior produção de leite de suas vacas. Entretanto, Jaster \& Wegner (1981) observaram uma perda de peso de $1,1 \mathrm{~kg} / \mathrm{dia}$ nos primeiros 30 dias pós-parto, embora estes autores tenham trabalhado com apenas 8 vacas, mas com produção média de $30,6 \mathrm{~kg} / \mathrm{dia}$.

Tabela 10. Efeitos dos tratamentos sobre a variação diária do peso corporal $(\mathrm{kg})$ durante o período experimental.

\begin{tabular}{cccccccc}
\hline \multicolumn{7}{c}{ Tratamentos } \\
Semana & C & DR & PC & PG & Média & EPM & P \\
\hline 1 & $-1,23$ & $-1,41$ & $-1,53$ & $-1,97$ & $-1,54$ & 0,208 & 0,3761 \\
2 & $-1,52$ & $-1,11$ & $-1,11$ & $-1,18$ & $-1,23$ & 0,174 & 0,6577 \\
3 & $-1,04$ & $-0,51$ & $-0,34$ & $-1,34$ & $-0,82$ & 0,169 & 0,1640 \\
4 & $-0,46$ & $-1,27$ & $-0,40$ & $-0,15$ & $-0,57$ & 0,186 & 0,1686 \\
5 & $-0,20$ & 0,42 & $-0,59$ & $-0,20$ & $-0,13$ & 0,193 & 0,3753 \\
6 & $-0,37$ & $-0,55$ & $-0,23$ & $-0,56$ & $-0,43$ & 0,199 & 0,9589 \\
Média & $\mathbf{- 0 , 8 1}$ & $\mathbf{- 0 , 7 4}$ & $\mathbf{- 0 , 7 1}$ & $\mathbf{- 0 , 9 1}$ & $\mathbf{- 0 , 7 9}$ & $\mathbf{0 , 0 7 8}$ & $\mathbf{0 , 6 6 8 4}$ \\
\hline C=controle; DR="drench"; PC=propionato de cálcio; PG=propileno glicol; EPM=erro padrão da \\
média; P=probabilidade estatística.
\end{tabular}


Tabela 11. Probabilidades estatísticas dos efeitos de tratamento e tempo e sua interação sobre a variação diária do peso corporal.

\begin{tabular}{lc}
\hline \multicolumn{1}{c}{ Efeito } & $\mathbf{P}$ \\
\hline Tratamentos & 0,6684 \\
Tempo & 0,0001 \\
Linear & 0,0001 \\
Quadrático & 0,0375 \\
Tratamento x Tempo & 0,6252 \\
\hline
\end{tabular}

Tabela 12. Equações de regressão para efeito de tempo, dentro de cada tratamento, sobre a variação diária do peso corporal $(\mathrm{kg} / \mathrm{d})$, coeficientes de determinação e probabilidades.

\begin{tabular}{|c|c|c|c|c|}
\hline \multirow[b]{2}{*}{ Trat } & \multirow[b]{2}{*}{ Equação } & \multirow[b]{2}{*}{$\mathbf{R}^{2}$} & \multicolumn{2}{|c|}{$\mathbf{P}$} \\
\hline & & & $\mathbf{L}$ & $\mathbf{Q}$ \\
\hline C & $V P=-1,691+0,2538 \mathrm{sem}$ & 0,0399 & 0,0060 & 0,9311 \\
\hline DR & $V P=-1,564+0,2374 \mathrm{sem}$ & 0,0763 & 0,0049 & 0,5178 \\
\hline PC & $V P=-1,500+0,2296 \mathrm{sem}$ & 0,0385 & 0,0142 & 0,2341 \\
\hline PG & $V P=-2,044+0,3302 \mathrm{sem}$ & 0,0441 & 0,0013 & 0,1539 \\
\hline Total & $V P=-2,180+0,6218$ sem $-0,0515$ sem $^{2}$ & 0,0362 & 0,0001 & 0,0375 \\
\hline
\end{tabular}

Trat.=tratamentos; C=controle; $\mathrm{DR}=$ "drench"; $\mathrm{PC}=$ propionato de cálcio; $\mathrm{PG}=$ propileno glicol; $\mathrm{R}^{2}=$ coeficiente de determinação; $\mathrm{P}=$ probabilidade; $\mathrm{L}=$ efeito linear; $\mathrm{Q}=$ efeito quadrático; $\mathrm{VP}=$ variação diária de peso; sem=semana; sem $^{2}=$ semana $\mathrm{x}$ semana 


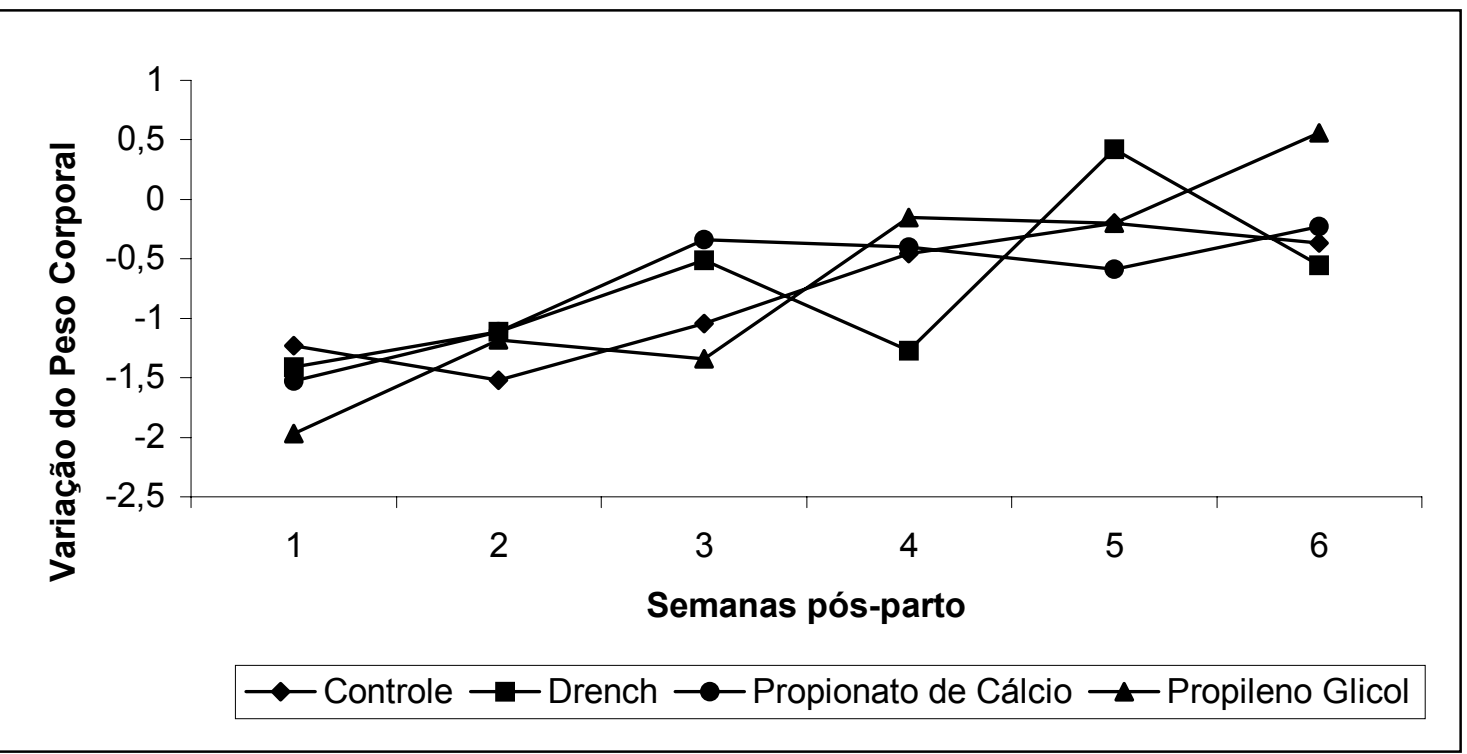

Figura 3- Efeito dos tratamentos sobre a variação diária do peso corporal $(\mathrm{kg})$ durante o período experimental.

\subsection{Produção de leite}

As vacas produziram em média $27,3 \mathrm{~kg}$ de leite/dia (Tabela 13 e Figura 4) durante o experimento, iniciando com $23,0 \mathrm{~kg}$ e finalizando na sexta semana com $29,7 \mathrm{~kg}$.

Houve interação entre os fatores principais tempo e tratamento $(P=0,0076)$ para a variável em questão. Porém, dentro de cada semana, a análise de variância não detectou diferenças. A produção de leite não sofreu influência dos tratamentos administrados $(P=0,5843)$. Entretanto, foi afetada pelo tempo (semanas) $(P=0,0001)$, apresentando efeito quadrático $(P=0,0019)$ (Tabela $14 \mathrm{e}$ Figura 4).

Ao analisar os resultados, verificou-se que no decorrer do tempo, os aumentos na produção foram de $12,5 \%$ da segunda semana em relação à primeira, de $6,1 \%$ da terceira semana em relação à segunda, e assim sucessivamente de 3,8\%, 3,4\%, 0,8\% (Tabela 13). Os tratamentos controle, "Drench" e propileno glicol apresentaram efeito linear no tempo $(P=0,0001)$, 
sendo que a cada semana houve um aumento da produção de 1,355, 1,337 e $0,999 \mathrm{~kg}$, respectivamente. Já o tratamento com propionato de cálcio sofreu um efeito quadrático no tempo $(P=0,0072)$. Estas equações estão apresentadas na Tabela 15.

Tabela 13. Efeitos dos tratamentos sobre a produção de leite $(\mathrm{kg})$ durante o período experimental.

\begin{tabular}{cccccccc}
\hline \multicolumn{7}{c}{ Tratamentos } \\
Semana & C & DR & PC & PG & Média & EPM & P \\
\hline 1 & 23,2 & 22,6 & 23,2 & 27,1 & 23,0 & 0,538 & 0,9229 \\
2 & 25,5 & 24,9 & 27,7 & 25,6 & 25,9 & 0,566 & 0,7539 \\
3 & 27,9 & 25,9 & 29,7 & 26,6 & 27,5 & 0,547 & 0,2437 \\
4 & 29,0 & 27,0 & 30,6 & 27,5 & 28,5 & 0,532 & 0,2494 \\
5 & 30,4 & 28,7 & 31,0 & 28,1 & 29,5 & 0,540 & 0,3075 \\
6 & 29,5 & 29,5 & 31,7 & 28,4 & 29,7 & 0,551 & 0,3500 \\
Média & $\mathbf{2 7 , 6}$ & $\mathbf{2 6 , 4}$ & $\mathbf{2 9 , 0}$ & $\mathbf{2 6 , 5}$ & $\mathbf{2 7 , 3}$ & $\mathbf{0 , 2 3 5}$ & $\mathbf{0 , 5 8 4 3}$ \\
\hline
\end{tabular}

$\mathrm{C}=$ controle; $\mathrm{DR}=$ "drench"; $\mathrm{PC}=$ propionato de cálcio; $\mathrm{PG}=$ propileno glicol; $\mathrm{EPM=erro} \mathrm{padrão} \mathrm{da}$ média; $\mathrm{P}=$ probabilidade estatística.

Tabela 14. Probabilidades estatísticas dos efeitos de tratamento e tempo e sua interação sobre a produção de leite.

\begin{tabular}{lc}
\hline \multicolumn{1}{c}{ Efeito } & $\mathbf{P}$ \\
\hline Tratamentos & 0,5843 \\
Tempo & 0,0001 \\
$\quad$ Linear & 0,0001 \\
Quadrático & 0,0019 \\
Tratamento x Tempo & 0,0076 \\
\hline
\end{tabular}


Tabela 15. Equações de regressão para efeito de tempo, dentro de cada tratamento sobre a produção de leite $(\mathrm{kg})$, coeficientes de determinação e probabilidades.

\begin{tabular}{llccc}
\hline & \multicolumn{1}{c}{ Equação } & $\mathbf{R}^{\mathbf{2}}$ & $\mathbf{L}$ & $\mathbf{P}$ \\
\hline Trat & \multicolumn{1}{c}{$\mathbf{Q}$} & $\mathbf{Q}$ \\
\hline C & Prod=22,851+1,355 sem & 0,0907 & 0,0001 & 0,0784 \\
DR & Prod=21,746+1,337 sem & 0,0981 & 0,0001 & 0,5996 \\
PC & Prod=19,486+4,649 sem $-0,447 \mathrm{sem}^{2}$ & 0,1972 & 0,0001 & 0,0072 \\
PG & Prod=23,061+0,999 sem & 0,0817 & 0,0001 & 0,1350 \\
Total & Prod=20,20+3,25 sem - $\mathbf{0 , 2 7 9} \mathbf{~ s e m}^{\mathbf{2}}$ & $\mathbf{0 , 1 0 2 0}$ & $\mathbf{0 , 0 0 0 1}$ & $\mathbf{0 , 0 0 1 9}$ \\
\hline
\end{tabular}

Trat.=tratamentos; C=controle; $\mathrm{DR}=$ "drench"; $\mathrm{PC}=$ propionato de cálcio; $\mathrm{PG}=$ propileno glicol; $R^{2}=$ coeficiente de determinação; $P=$ probabilidade $L=$ efeito linear; $Q=$ efeito quadrático; Prod=produção de leite; sem=semana; sem $^{2}=$ semana $\mathrm{x}$ semana

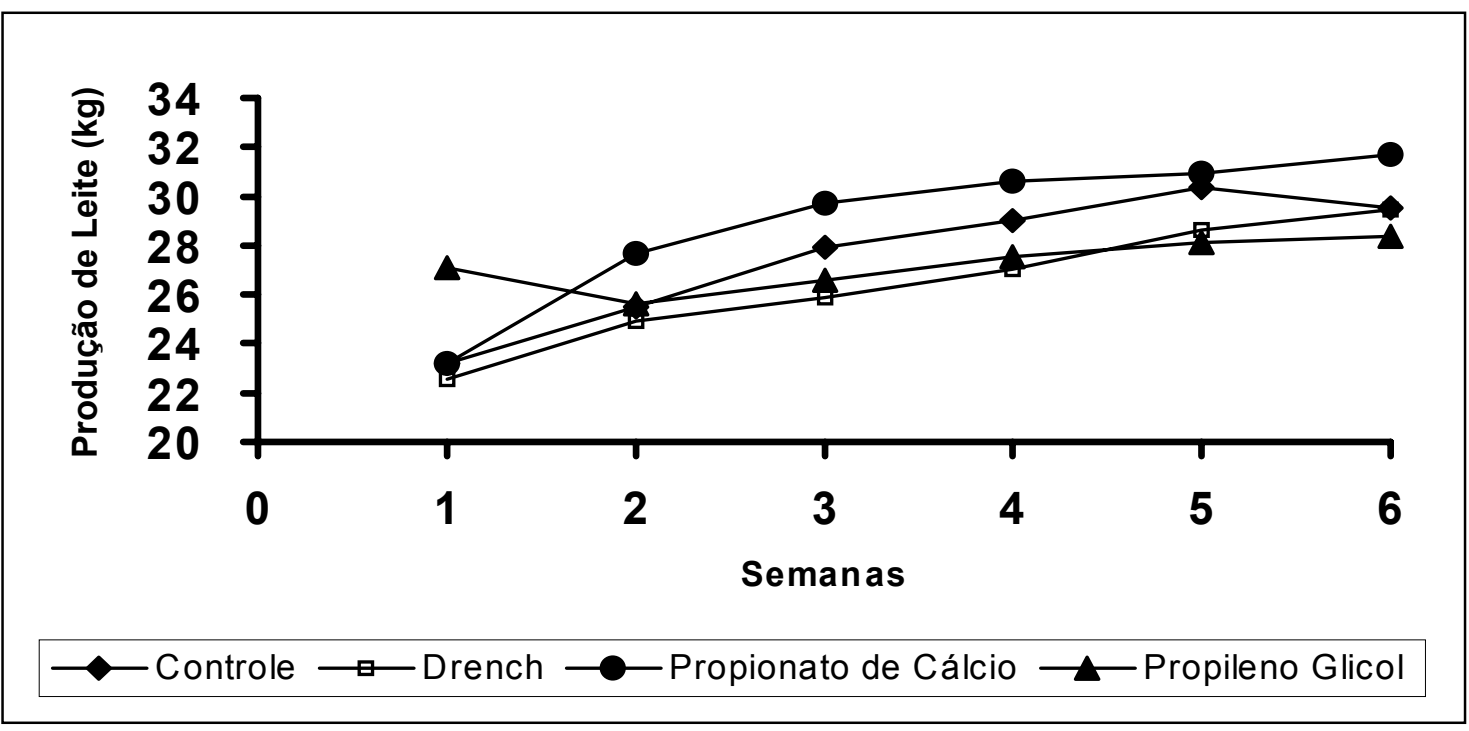

Figura 4- Efeitos dos tratamentos sobre a produção de leite $(\mathrm{kg})$ durante o período experimental.

A média diária de produção leite dos animais suplementados com PG neste experimento foi de $26,5 \mathrm{~kg}$, inferiores aos $31,2 \mathrm{~kg}$ encontrados por Miyoshi et al. (2001), que forneceram o mesmo volume $(500 \mathrm{~mL})$ de PG. Da mesma forma, foram inferiores aos de Fonseca (1997) que encontrou média de $27,03 \mathrm{~kg}$, porém tendo administrado apenas 15 doses de $300 \mathrm{~mL}$ de PG. É necessário frisar que neste caso as produções foram computadas da segunda à $12^{a}$ semana de lactação. Resultados superiores $(31,18 \mathrm{~kg} / \mathrm{dia})$ foram obtidos por Juchem (2000), tendo utilizado $300 \mathrm{~mL} /$ dia de PG nos 21 dias pré-parto. Da 
mesma forma, Stokes \& Goff (2001) obtiveram médias de 39,7, 41,1 e 42,8, para os grupos controle, propionato de cálcio e propileno glicol, respectivamente, utilizando-se apenas duas doses de $300 \mathrm{~mL}$ de PG e duas de $680 \mathrm{~g}$ de propionato de cálcio. Os resultados para o propionato de cálcio do presente experimento $(28,98 \mathrm{~kg})$ foram inferiores aos $41,1 \mathrm{~kg}$ encontrados por Stokes \& Goff (2001), aos 46 kg de Don Aslup \& Schlatter (1997a), aos 47,8 kg de Dubois \& Schlatter (1997) e aos $45 \mathrm{~kg}$ de Don Aslup \& Schlatter (1997b).

No experimento realizado por Rukkwamsuk et al. (1998), onde os autores trabalharam com animais apresentando excesso de peso e animais sob restrição alimentar, os autores obtiveram praticamente a mesma produção de leite na primeira semana ( 27,1 vs. 27,3$)$. Já da segunda até a $12^{a}$ semana de lactação, as produções foram de 35,5 e $39 \mathrm{~kg}$ para as vacas com excesso de peso e em restrição, respectivamente.

As diferenças observadas nos diversos experimentos podem ser atribuídas a diferentes méritos genéticos para produção de leite dos animais utilizados nos respectivos experimentos, ou as condições de manejo e nutrição como um todo, adotados nos grupos experimentais.

\subsection{Eficiência reprodutiva}

\subsubsection{Dias para ocorrência do primeiro cio detectável pós-parto}

Não houve diferença entre os tratamentos $(P=0,7399)$ com relação ao aparecimento do primeiro cio detectável pós-parto. Em média, as vacas apresentaram o primeiro cio aos 69,5 dias pós-parto, considerando todos os tratamentos (Tabela 16 e Figura 5). Este resultado é semelhante ao encontrado por Heuwieswer et al. (1994) que foi de 69,3 dias e ao encontrado por De Vries et al. (1998) que obtiveram em média 69,4 dias.

Este resultado foi superior ao obtido por Thatcher \& Wilcox (1973) de 43 dias, e Miyoshi (1995) que encontrou 53,1 dias para os animais que receberam 
$500 \mathrm{~mL}$ de propileno glicol e 56,8 dias para os animais do grupo controle. Da mesma forma, Jorritsma et al. (2000) observaram um intervalo de 54,1 dias para o aparecimento de cio, sem a administração de suplementos energéticos. Reist et al. (2000) também encontraram valores inferiores a 43 dias para vacas que apresentaram cio precocemente (<30dias) e 62 dias para as que apresentaram cio tardiamente ( $>31$ dias).

Já Staples et al. (1990) observaram cio aos 47 dias para as vacas que apresentaram concentrações de progesterona elevados aos 21,9 dias pósparto. Schneider et al. (1981) também observaram a manifestação do primeiro cio pós-parto em média de 49 dias, com uma variação de 8 a 127 dias, e Schindler et al. (1991) obtiveram em média 39,3 dias para as vacas primíparas e multíparas sem qualquer problema reprodutivo pós-parto. Estas diferenças encontradas nos diversos experimentos citados acima podem ser devidas a diferentes práticas de manejo na detecção de cio, assim como a diferentes níveis nutricionais, sanitários e produção de leite das vacas.

No Brasil, Fonseca (1997) registrou média para o aparecimento do primeiro cio de 40,33 dias para animais com concentrações normais e 51,6 dias para animais com acetonemia, contudo são valores inferiores aos 69,5 dias encontrados neste experimento. Entretanto, há necessidade de se ressaltar que a identificação de cio no referido experimento foi realizado através do sistema "Heat Watch", instrumento de detecção de cio operado por radiotelemetria. Resultados mais expressivos e também inferiores aos da presente pesquisa foram registrados por Juchem (2000), cujas médias foram de 22,2 dias até a primeira ovulação para os animais que receberam propileno glicol e 18,6 dias para os animais do grupo controle, detectados com o auxílio de ultra-som.

Resultados superiores aos deste experimento (69,5 dias) foram encontrados por Gillund et al. (2000) que encontraram em média 77,4 dias e Veerkamp et al. (2001), que obtiveram também em média 89 dias. Da mesma forma, Buckley et al. (2000) analisaram grupos de alto e médio mérito genético 
para produção de leite e não encontraram diferença entre os dois grupos, obtendo 70 e 69 dias pós- parto para o primeiro serviço, respectivamente.

Em condições normais, a primeira onda de crescimento folicular e ovulação no pós-parto acontece entre 10-14 dias após o ponto mais baixo de balanço energético negativo (Beam \& Butler, 1997), ou seja, entre 14-21 dias pós parto e $5 \%$ das vacas permanecem em anestro (Morrow et al.,1966; Marion et al., 1968). Grande proporção destes cios acontecem sem a manifestação clínica, chamados de cios silenciosos, os quais ocorreram em $25,9 \%$ dos animais normais (Thatcher \& Wilcox, 1973). Segundo alguns autores, é o resultado de uma deficiência de progesterona pós-parto, em função da ausência de um corpo lúteo funcional prévio. Já aqueles que manifestam as características do cio, sofreram luteinização de alguns folículos, formando tecido luteínico capaz de secretar concentrações de progesterona suficientes para sensibilizar receptores hipotalâmicos a responder à baixas concentrações de estrógeno, hormônio responsável pela manifestação clínica do cio.

Nas vacas de alta produção de leite, o intervalo para a primeira ovulação é mais longo, provavelmente 10 dias, bem como a percentagem de vacas em anestro, mais elevado (Stevenson 1999; De Vries \& Veerkamp, 2000). A razão para estes intervalos prolongados pode ser explicado parcialmente pelo balanço energético negativo maior destes animais. $O$ balanço energético negativo e a perda de peso normais no pós-parto, reduzem os pulso de $\mathrm{LH}$, e consequentemente atrasam a retomada da função ovariana, permanecendo as vacas em anestro (Beam \& Butler,1998; Butler,2000).

Britt (1992) sugeriu que o crescimento folicular pode ser afetado pelo acentuado BEN durante o pós-parto, resultando em menor secreção de $\mathrm{P}_{4}$, especialmente no terceiro, quarto e quinto ciclo estral. Esta sugestão é apoiada pelo trabalho de Villa-Godoy et al. (1998) que encontraram nas vacas com BEN mais acentuado menor concentração plasmática de $\mathrm{P}_{4}$ no segundo e terceiro ciclo estral que as vacas em melhor BEN. Nos bovinos, a progesterona é o hormônio responsável pela manutenção da prenhez. As vacas cujas 
inseminações resultaram em prenhez, observou-se que as concentrações de progesterona eram maiores nos primeiros 10 dias após a inseminação artificial (Mann,1999).

As perdas de peso e subnutrição em bovinos causam uma diminuição das concentrações de progesterona plasmáticas (Beal et al., 1978; Gombe \& Hansel, 1973), tendo como conseqüência um atraso no aparecimento do primeiro cio. Os sistemas de alimentação durante o meio e final da lactação devem objetivar suprir os nutrientes para mantença, produção e acúmulo de reserva para a lactação seguinte. No presente experimento, uma das prováveis causas do atraso no aparecimento do cio detectável pós-parto (69,5 dias) pode ser a falha na detecção do cio, visto que a observação era realizada apenas visualmente, assim como a alta incidência de cistos ovarianos, principalmente na fazenda que contribuiu com um maior número de animais para o experimento.

Tabela 16. Efeito dos tratamentos sobre o aparecimento do primeiro cio (dias), serviço/concepção e período de serviço (dias), durante o período experimental.

\begin{tabular}{|c|c|c|c|c|c|c|c|}
\hline \multirow[b]{2}{*}{ Variável } & \multicolumn{4}{|c|}{ Tratamentos } & \multirow{2}{*}{ Média } & \multirow{2}{*}{ EPM } & \multirow{2}{*}{$\mathrm{P}$} \\
\hline & $\mathrm{C}$ & DR & PC & PG & & & \\
\hline Cio (dias) & 73,9 & 72,6 & 60,6 & 71,2 & 69,5 & 2,790 & 0,7399 \\
\hline n (cio) & 35,0 & 39,0 & 38,0 & 37,0 & & & \\
\hline$S / C$ & 2,2 & 2,3 & 2,3 & 2,2 & 2,2 & 0,124 & 0,9342 \\
\hline $\mathrm{n}(\mathrm{S} / \mathrm{C})$ & 40,0 & 41,0 & 39,0 & 33,0 & & & \\
\hline PS (dias) & 160,2 & 162,2 & 162,2 & 205,2 & 172,6 & 11,556 & 0,8874 \\
\hline$n(P S)$ & 29,0 & 33,0 & 32,0 & 32,0 & & & \\
\hline
\end{tabular}




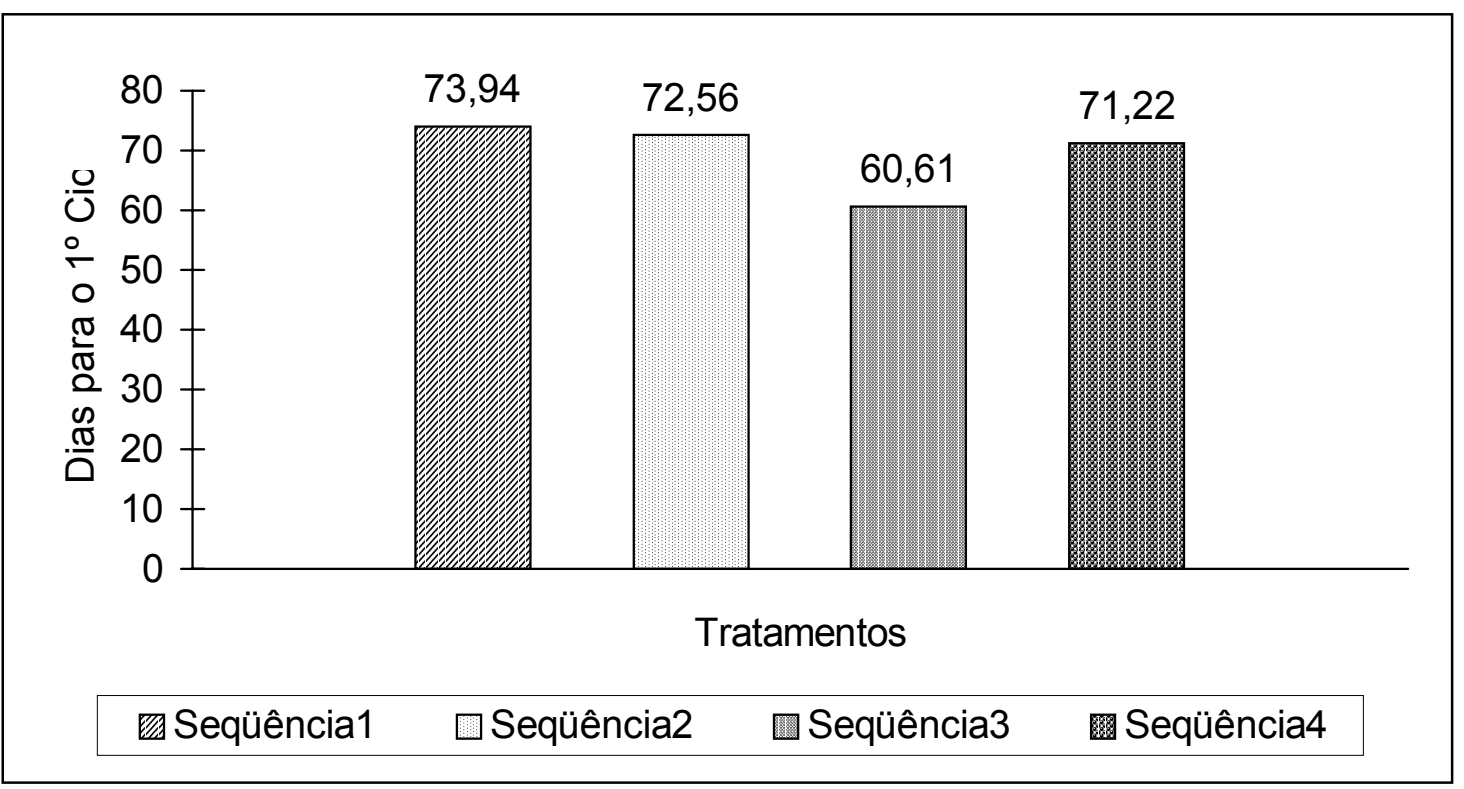

Figura 5- Efeitos dos tratamentos sobre o número de dias para apresentação do primeiro cio dos animais.

\subsubsection{Número de serviços por concepção}

O número médio de serviços por prenhez foi de 2,2, não havendo diferença $(P=0,9342)$ entre os tratamentos (Tabela 16 e Figura 6$)$. Dados muito próximos aos deste experimento foram também encontrados por autores como Coleman (1985), Miyoshi (1995), Foot \& Rieck (1999) e Veerkamp et al. (2001), os quais encontraram 2,3 serviços/concepção para o grupo controle. Já Staples et al. (1990) obtiveram 2,38 serviços/concepção para aqueles animais que ovularam até 21 dias após o parto. Da mesma forma, Smith \& Wallace (1998) obtiveram 2,1 serviços/concepção para as vacas que ciclaram após os 21 dias pós-parto. 


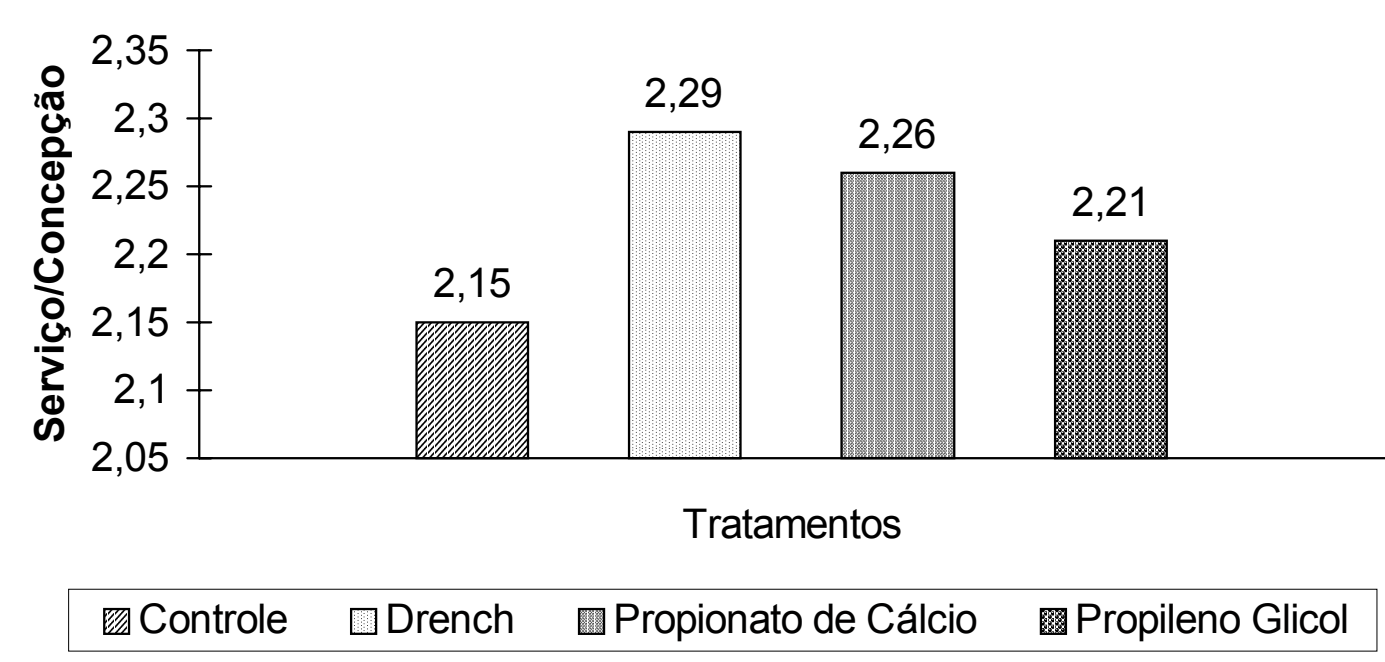

Figura 6- Efeitos dos tratamentos sobre o número de serviços/concepção durante o período experimental.

Valores inferiores aos deste experimento $(2,23)$ foram encontrados por Miyoshi et al. (1995) de 1,7 serviço/concepção nos animais também suplementados com $500 \mathrm{~mL}$ de propileno glicol. Valores também inferiores em animais sem suplementação, foram observados por Gearhart et al. (1990), Heuer et al. (1999); Heuwieser et al. (1994); Foot e Rieck (1999), Reist et al. (2000), Gillund et al. (2000) e Keady et al. (2000), os quais observaram 1,8; 1,$82 ; 1,6 ; 1,9 ; 1,49 ; 1,34$ e 1,81 serviços/concepção, respectivamente. Quando se comparou com animais que ciclaram até 43 dias pós-parto, valores inferiores, aos 2,23 deste experimento, foram observados por Schneider et al. (1981) com 1,5 e Staples et al. (1990) que obtiveram 1,77 serviços/concepção. Buckley et al. (2000), trabalhando com grupos de alto e médio mérito genético para produção de leite, obtiveram 2,05 e 1,93 serviços/concepção, respectivamente.

Resultados superiores aos deste experimento foram encontrados por Smith \& Wallace (1998), com 2,7 S/C para as vacas que ciclaram antes do dia 21 pós-parto; Heuwieser et al. (1994) com 3,3 serviços/concepção em animais com menos dias para o primeiro serviço e menores produções e Foot \& Rieck 
(1999) com 2,6 serviços/concepção para vacas com algum problema reprodutivo.

O número de serviços/concepção é uma variável que resulta de uma observação de cio bem feita, inseminação bem conduzida e bem sucedida, boa taxa de fertilização e baixa taxa de morte embrionária precoce (Ayalon, 1978).

O número de serviços/concepção obtido no presente experimento foi relativamente alto, uma vez que até 2,0 S/C é considerado normal ou aceitável. O valor mais alto obtido $(2,3)$ pode ser devido a uma associação dos fatores acima citados, e a não exclusão de vacas repetidoras de cio, para efeito de análises estatística.

A literatura clássica define uma categoria de vacas como repetidoras de cio, referindo- se aquelas vacas que recebem quatro ou mais inseminações e não ficam prenhas (Casida, 1961). Estudos de vacas repetidoras de cio mostraram que estas fêmeas são diferentes, uma vez que apresentam maior taxa de morte embrionária (Ayalon, 1978). Esta mortalidade aconteceu em dois estágios diferentes, porém ambos considerados precoces, sendo um, pouco tempo após a concepção e outro posterior ao período de alongamento ou filamentoso. Nesta última fase, os autores observaram que os embriões de vacas repetidoras eram menores, devido a um ambiente uterino adverso, o que pode ter provocado falha no bloqueio do processo luteolítico. Este problema pode ter ocorrido e contribuído para aumentar $\mathrm{o}$ número de serviços/concepção, uma vez que algumas vacas em todos os tratamentos repetiram cio regularmente sem nenhuma causa aparente.

As doenças metabólicas também estão relacionadas com menores taxas de concepção. A lipidose hepática, resultante das altas taxas de lipólise observadas no pré e pós-parto, pode também estar relacionada com os maiores números de serviços/concepção. Nas vacas leiteiras, no período de transição, observa-se uma diminuição do consumo de matéria seca, o que também pode reduzir o fluxo sangüíneo hepático e a causar consequentemente a redução da gliconeogênese. Uma diminuição da glicose plasmática tem mostrado inibir a 
secreção de LH, hormônio ligado não apenas ao reinício da atividade ovariana pós-parto, como também com a ovulação e a divisão meiótica do ovócito. Porém, neste experimento, a perda de peso das vacas no pós-parto foi normal, não devendo desta maneira ter contribuído para aumentar o número de serviços/concepção.

A inseminação bem sucedida requer, entre outros fatores, que seja realizada no momento adequado, respeitando momento de ovulação, capacitação espermática, maturação ovular no trato genital feminino, capacidade fertilizante do espermatozóide e bloqueio espermático do óvulo, para evitar polispermia. Talvez falhas em um ou mais destes itens também possa ter contribuído para aumentar o número de serviços/concepção.

\subsubsection{Período de serviço}

O período médio de serviço, neste experimento, foi de 172,6 dias (Tabela 16 e Figura 7). Esta variável não foi afetada $(P=0,8874)$ pelos tratamentos. Entretanto, numericamente as vacas que receberam o PG demoraram mais para se tornarem prenhes (205,2 dias), quando comparadas às do grupo controle, DR e PC que apresentaram um período de serviço de 160,2, 162,2, e 162,2 dias, respectivamente. Talvez, se houvesse um número maior de animais em cada grupo, poderia se detectar diferença estatística entre o grupo de vacas tratadas com propileno glicol e os demais tratamentos . 


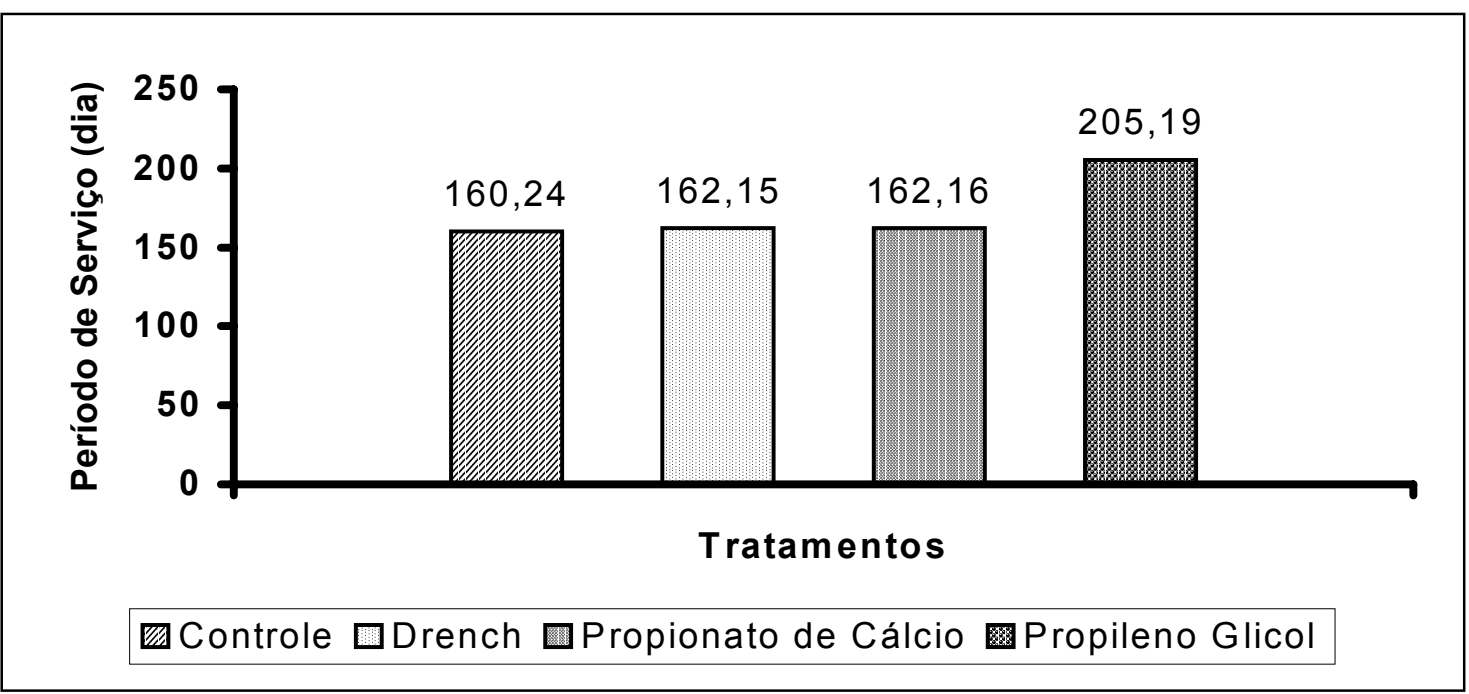

Figura 7- Efeitos dos tratamentos sobre o período de serviço durante o período experimental

Resultados com, menor período de serviço, foram encontrados por Miyoshi (1995), para o grupo que recebeu $500 \mathrm{~mL}$ de propileno glicol (95,5 dias e para o grupo controle 111,5 dias). Heuwieser et al. (1994), em um levantamento feito em quatro propriedades, encontraram 148,7, 111,5, 120,6 e 104 dias para as propriedades 1, 2, 3 e 4, respectivamente. Da mesma forma, Jorritsma et al. (2000) encontraram 103,4 dias; Gillund et al. (2000) obtiveram 87dias; Staples et al. (1990) verificaram 133 e 88 dias para as vacas que tiveram a retomada da atividade ovariana precoce $(<21$ dias ) e tardia (>22dias), respectivamente. Já, Smith \& Wallace (1998) obtiveram 138,6 e 107,2 dias para as vacas que retomaram a atividade ovariana antes e após o dia 21 pós-parto, respectivamente.

Levantamentos realizados por outros pesquisadores também mostraram menores períodos de serviço em relação ao encontrado no presente experimento. Entre eles estão: Schneider et al. (1981), 88 dias; Schindler et al. (1991), 146 dias para vacas primíparas e multíparas sem complicações reprodutivas no pós-parto, Heuer et al. (1999), 110 dias e os 127 dias de Veerkamp et al.( 2001). 
No Brasil, em um levantamento na Zona da Mata em Minas Gerais, Ferreira et al. (1984) constataram um período de serviço médio de 240 dias em 1.634 vacas sem suplementação.

O período de serviço, em bovinos leiteiros, é influenciado por diversos fatores:

- o aparecimento do cio no pós-parto é uma das condições essenciais para a redução do período de serviço, o qual deve acontecer antes dos 60 dias, valores estes inferiores aos da presente pesquisa.

- o período de serviço está na dependência do período de espera voluntária, eficiência de observação de cio e taxa de concepção (Ferguson, 1995). O período de espera voluntária visa respeitar o período de involução uterina, o qual varia de acordo com a ordem de parição, tipo de parto, infecção uterina e alterações metabólicas, permitindo assim o estabelecimento de uma nova gestação.

- o sucesso de um programa de inseminação artificial se inicia com o uso de métodos eficientes e precisos de observação de cios, técnicas apropriadas de manipulação do sêmen e inseminação em tempo correto em relação à ovulação. No contexto, a detecção do cio é citada como a falha mais comum e onerosa, que se traduz em perdas de produção de leite, menor número de bezerros nascidos/vaca durante a vida produtiva, excesso de dias abertos e aumento da taxa de descarte por reprodução (Walker et al., 1996).

- a aceitação da monta é um dos sinais mais conclusivos de que a vaca está em estro (Esslemont et al.1976). A determinação da concentração de progesterona plasmática, possibilitou a observação de que 5 a $30 \%$ das vacas inseminadas não se encontravam em estro (Senger et al.,1984). Já, Sturman et al. (2000) observaram que $19 \%$ das vacas inseminadas estavam em gestacão inicial. Estas inseminações são responsáveis por $17 \%$ das perdas embrionárias. Enfim, falhas na detecção do estro e/ou na taxa de concepção diminuem a taxa de prenhez, aumentando o período de serviço médio do rebanho e consequentemente, diminuindo a eficiência reprodutiva. 
- o número de serviços/concepção neste experimento foi relativamente elevado, o que pode ter contribuído de forma indireta para o prolongamento deste período. Thatcher \& Wilcox (1973) observaram que o número de serviços/concepção esteve associado ao número de cios observados desde o parto até os 60 dias. Houve um declínio significativo do número de serviços necessários com o aumento de cios observados no pós-parto, com menor taxa de não retorno e também período de serviço menor. A grande variação no número de dias para o aparecimento do primeiro cio pós-parto pode estar mascarando animais em anestro verdadeiro e animais com cios silenciosos. $O$ anestro é um fator de extrema importância na determinação do período de serviço, uma vez que atrasa o intervalo para a primeira inseminação fértil. A incidência de anestro foi de $28 \%, 10 \%$ e $25 \%$ nos estudos de Staples et al. (1990), King et al. (1976) e Thatcher \& Wilcox (1973), respectivamente.

Estes fatores podem ser responsáveis pelo elevado período de serviço das vacas em estudo.

\subsection{Parâmetro sangüíneo}

\subsection{1 Ácidos graxos livres (AGL)}

As concentrações plasmáticas dos ácidos graxos livres analisados das vacas não sofreram interação dos efeitos tempo $x$ tratamento $(P=0,4791)$, conforme pode ser observado na Tabela 18 e Figura 8 . O fornecimento de "drench", propionato de cálcio e propileno glicol não afetaram esta variável $(P=0,4298)$. Entretanto, houve efeito de tempo $(P=0,0001)$, apresentando comportamento linear $(P=0,0001)$ (Tabelas 18 e 19). 
Tabela 17. Efeitos dos tratamentos sobre as concentrações de ácidos graxos livres ( $\mu \mathrm{eq} / \mathrm{L})$ durante o período experimental.

\begin{tabular}{cccccccc}
\hline \multicolumn{7}{c}{ Tratamentos } \\
Semana & C & DR & PC & PG & Média & EPM & P \\
\hline 1 & 521,0 & 464,7 & 470,6 & 440,8 & 474,7 & 18,044 & 0,3118 \\
2 & 449,9 & 433,3 & 428,2 & 369,0 & 420,0 & 15,742 & 0,3186 \\
3 & 377,9 & 405,0 & 386,1 & 352,8 & 380,4 & 15,030 & 0,9228 \\
4 & 317,5 & 385,7 & 331,2 & 274,0 & 327,1 & 15,051 & 0,1791 \\
5 & 291,6 & 312,7 & 267,2 & 248,0 & 279,9 & 11,369 & 0,4900 \\
Média & $\mathbf{3 9 2 , 2}$ & $\mathbf{4 0 1 , 3}$ & $\mathbf{3 7 4 , 4}$ & $\mathbf{3 3 8 , 4}$ & $\mathbf{3 7 6 , 6}$ & $\mathbf{7 , 2 1 8}$ & $\mathbf{0 , 4 2 9 8}$ \\
\hline
\end{tabular}

C=controle; DR="drench"; PC=propionato de cálcio; $\mathrm{PG}=$ propileno glicol; $\mathrm{EPM}=$ erro padrão da média; $\mathrm{P}=$ probabilidade estatística.

Tabela 18. Probabilidades estatísticas dos efeitos de tratamento e tempo e sua interação sobre as concentrações de ácidos graxos livres.

\begin{tabular}{lc}
\hline \multicolumn{1}{c}{ Efeito } & $\mathbf{P}$ \\
\hline Tratamentos & 0,4298 \\
Tempo & 0,0001 \\
$\quad$ Linear & 0,0001 \\
Quadrático & 0,1471 \\
Tratamento x Tempo & 0,4791 \\
\hline
\end{tabular}

Tabela 19. Equações de regressão para efeito de tempo, dentro de cada tratamento, sobre as concentrações de ácidos graxos livres ( $\mu \mathrm{eq} / \mathrm{L})$, coeficientes de determinação e probabilidades.

\begin{tabular}{llccc}
\hline & & & \multicolumn{2}{c}{$\mathbf{P}$} \\
\multicolumn{1}{c}{ Trat } & Equação & $\mathbf{R}^{\mathbf{2}}$ & $\mathbf{L}$ & $\mathbf{Q}$ \\
\hline C & AGL $=569,064-59,172 \mathrm{sem}$ & 0,2028 & 0,0001 & 0,5322 \\
DR & AGL $=505,559-35,042 \mathrm{sem}$ & 0,0799 & 0,0001 & 0,6312 \\
PC & AGL $=528,388-50,524 \mathrm{sem}$ & 0,1579 & 0,0001 & 0,5277 \\
PG & AGL $=481,406-48,085 \mathrm{sem}$ & 0,1939 & 0,0001 & 0,5748 \\
Total & AGL=521,155-48,239 sem & $\mathbf{0 , 1 4 5 2}$ & $\mathbf{0 , 0 0 0 1}$ & $\mathbf{0 , 1 4 7 1}$ \\
\hline
\end{tabular}

Trat.=tratamentos; $\mathrm{C}=$ controle; $\mathrm{DR}=$ "drench"; $\mathrm{PC}=$ propionato de cálcio; $\mathrm{PG}=$ propileno glicol; $\mathrm{R}^{2}=$ coeficiente de determinação; $\mathrm{P}=$ probabilidade; $\mathrm{L}=$ efeito linear; $\mathrm{Q}=$ efeito quadrático; $A G L=$ concentração de ácidos graxos livres; sem=semana 


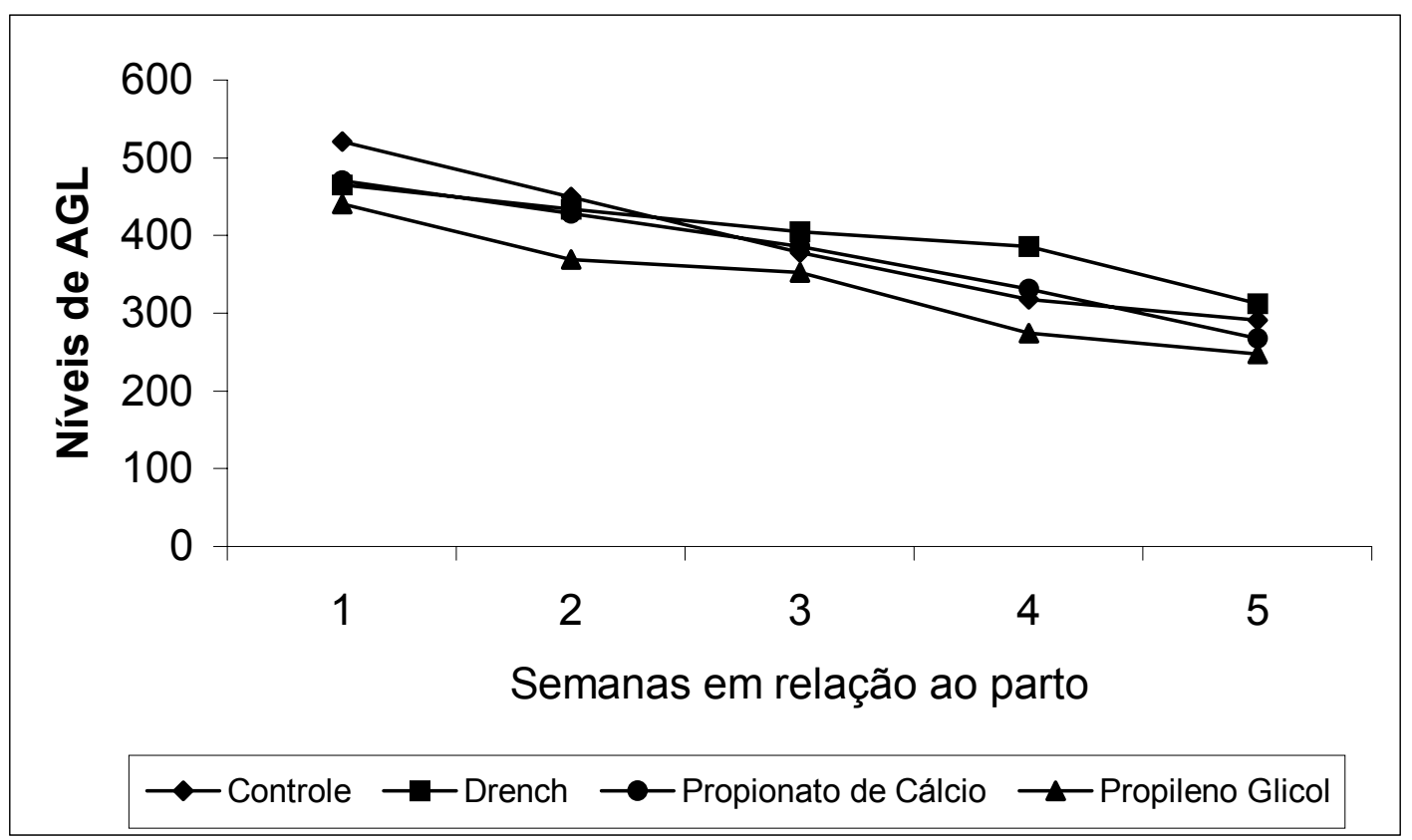

Figura 8- Efeito dos tratamentos sobre as concentrações ( $\mu$ eq/L) de ácidos graxos livres durante o período experimental.

A média de ácidos graxos livres durante o período experimental foi de 376,6 $\mu \mathrm{eq} / \mathrm{L}$ (Tabela 17).

$\mathrm{Na}$ semana anterior ao parto, as vacas apresentaram em média 420 $\mu e q / L$ de ácidos graxos livres. Já na primeira semana pós-parto, a média de AGL subiu para 474,7 $\mu \mathrm{eq} / \mathrm{L}$. Observou-se que a média de AGL durante o experimento decresceu em $41 \%$ da quinta semana pós-parto em relação à primeira, diminuindo por semana 48,24 $\mu \mathrm{eq} / \mathrm{L}$ (equação na Tabela 19).

Estes valores estão dentro dos limites encontrados por outros pesquisadores. Vasquez-Añon et al. (1994) encontraram $300 \mu \mathrm{eq} / \mathrm{L}$ no dia -10 do parto, e 1014, 700, 445, 320 e $300 \mu \mathrm{eq} / \mathrm{L}$ nos dias zero, 5, 10, 20 e 25 pósparto, respectivamente. Blum et al. (1985) encontraram $121 \mu \mathrm{eq} / \mathrm{L}$ no período seco e 378, 386, 263, 222, 213 e $170 \mu \mathrm{eq} / \mathrm{L}$ para primeira, segunda, terceira, quarta, quinta e sexta semanas pós-parto, respectivamente. Staples et al. (1990) não encontraram efeito de interação entre tempo e tratamento e 
observaram uma diminuição nas concentrações de AGL da primeira comparada à nona semana, sendo $612 \mu \mathrm{eq} / \mathrm{L}$ e $237 \mu \mathrm{eq} / \mathrm{L}$, respectivamente. Estes autores relacionaram no mesmo experimento o efeito da concentração de AGL sobre a atividade ovariana e observaram que as concentrações de AGL não foram um bom indicador do "status" energético. As concentrações foram de 348, 351 e $346 \mu \mathrm{eq} / \mathrm{L}$, para as vacas que retornaram precocemente, tardiamente e que não retornaram à atividade ovariana, respectivamente.

Rabelo et al. (2001) trabalhando com vacas alimentadas com dietas de elevada ou baixas concentração energética, 97 dias antes do parto, observaram menores valores plasmáticos de AGL parta os animais recebendo mais energia (76,4 vs. $89,9 \mu \mathrm{eq} / \mathrm{L}$ ) respectivamente. Quando o parto é antecipado, e as vacas não experimentam a diminuição de consumo de matéria seca que ocorre nos dias que antecedem o parto, as concentrações de AGL não são elevadas quando comparadas aos das vacas com parto não induzido. Bremmer et al. (1999) observaram maiores concentrações de AGL (818 $\mu \mathrm{eq} / \mathrm{L})$ no dia do parto para as vacas cujo parto não foi induzido com prostaglandina. As vacas que foram induzidas com prostaglandinas tiveram menores concentrações de AGL (371 $\mu \mathrm{eq} / \mathrm{L}$ ) no pré-parto quando comparadas com as vacas que não foram induzidas (475 $\mu \mathrm{eq} / \mathrm{L})$. Os autores acreditam que possivelmente isto seja devido a um maior consumo de MS.

Em experimento com vacas obesas e vacas com restrição alimentar, Rukkwamsuk et al. (1998) observaram que uma semana antes do parto não houve diferença na concentração de AGL entre os dois grupos (200 $\mu \mathrm{eq} / \mathrm{L}$ vs. $80 \mu \mathrm{eq} / \mathrm{L}$, respectivamente). Entretanto, na metade da semana que antecedia o parto e na semana do parto as vacas obesas aumentaram de forma significativa as concentrações de AGL (900 e $1200 \mu \mathrm{eq} / \mathrm{L}$ ), enquanto as vacas magras passaram de 200 para $300 \mu \mathrm{eq} / \mathrm{L}$. Estas diferenças continuaram maiores na segunda, terceira e sexta semanas pós-parto para as vacas obesas. Já na $12^{a}$ semana, as concentrações diminuíram para valores semelhantes aquelas de 
uma semana antes do parto. Em outro experimento, Rukkwamsuk et al. (2000), estudando vacas sob restrição energética e superalimentadas, não encontraram diferença na concentração de AGL na última semana de gestação (250 vs. 250 $\mu e q / L)$, enquanto que na metade da semana pré-parto, primeira, segunda e terceira semanas pós-parto as concentrações foram de 700 e 1500, 600 e 1400, 600 e 1200, 400 e $800 \mu \mathrm{eq} / \mathrm{L}$ para as vacas com restrição e superalimentadas, respectivamente. Bertics et al. (1992) encontraram $500 \mu \mathrm{eq} / \mathrm{L}$ de $A G L$ no $14^{\circ}$ dia pós-parto em vacas com restrição e 824 para vacas que não tiveram restrição. No $28^{\circ}$ dia as concentrações foram de 395 e $534 \mu \mathrm{eq} / \mathrm{L}$ para as vacas sem ingestão forçada e com ingestão forçada, respectivamente. Veenhuizen et al. (1991) encontraram, em animais sem suplementação, concentrações de AGL de $520,550,600,430,500$ e $380 \mu \mathrm{eq} / \mathrm{L}$, para os dias $-10,0,10,21,28$ e $42 \mathrm{em}$ relação ao parto, respectivamente. Stokes \& Goff (2001) encontraram 533, 465 e $543 \mathrm{meq} / \mathrm{L}$ de AGL para os grupos controle, propileno glicol e propionato de cálcio, respectivamente. Por outro lado, Fonseca (1997) não encontrou diferença entre o grupo controle $(415 \mathrm{meq} / \mathrm{L})$ e o grupo que recebeu propileno glicol (384 meq/L). Juchem (2000) encontrou $330 \mathrm{meq} / \mathrm{L}$ para os animais tratados com propileno e $345 \mathrm{meq} / \mathrm{L}$ para o grupo controle e não observou interação entre tempo e tratamento. Miyoshi (1995) encontrou diminuição dos AGL plasmáticos no grupo tratado com propileno glicol quando comparado com o grupo testemunha (302 vs. $386 \mu \mathrm{eq} / \mathrm{L}$ ). Buckley et al. (2000) não observaram diferença entre vacas de alto e baixo mérito genético para produção de leite em relação aos níveis circulantes de AGL.

Holcomb et al. (2001) obtiveram valores médios (pré e pós-parto) de 908, 799, 650 e $674 \mu \mathrm{eq} / \mathrm{L}$ de AGL, para animais alimentados no pré-parto com dieta à vontade (alto teor de forragem), dieta restrita (alto teor de forragem), dieta à vontade (baixo teor de forragem) e dieta restrita (baixo teor de forragem), respectivamente. Os resultados do presente experimento mostraram que as concentrações de AGL aumentaram nos dias que antecedem o parto e na 
primeira semana de lactação, com uma diminuição nas semanas seguintes. Este aumento acentuado do $A G L$ neste período deve-se a dois fatores principais: primeiro, devido uma diminuição acentuada na ingestão de MS e segundo, ao aumento dos hormônios lipolíticos associados com o parto. Em termos de manejo nutricional está claro que pelas características metabólicas e endócrinas inerentes ao período de transição, a deficiência ou excesso nutricional apresentam resultados indesejáveis. Rabelo et al. (2001) mostraram que houve aumento da IMS e menores níveis de AGL quando aumentaram a densidade energética da dieta. Por outro lado, Rukkwamsuk et al. (1998) encontraram maior concentração de AGL, menor capacidade do fígado em metabolizar ácidos graxos com desenvolvimento de lipidose hepática nas vacas superalimentadas, no período pré-parto. Rabiee et al. (1997) também encontraram problemas reprodutivos em vacas obesas e Holcomb et al. (2001) encontraram pouco aumento de consumo de MS e produção de leite em vacas que tiveram restrição alimentar no pré-parto.

As vacas do presente experimento, nas duas propriedades, tinham um bom manejo nutricional no período pré e pós-parto. Isto pode ser comprovado pelo não aparecimento de animais com cetose clínica pelos níveis de AGL, que foram relativamente baixos quando comparados com outros experimentos. $\mathrm{Da}$ mesma forma também não foram diagnosticados animais com febre do leite.

Provavelmente o manejo nutricional aplicado, a produção de leite obtida (não considerada elevada), e o pequeno número de animais utilizado não permitiram a verificação de diferenças significativas entre os tratamentos, para os parâmetros avaliados. 


\section{CONCLUSÕES}

O uso de propileno glicol, propionato de cálcio ou Dairy Power Drench $\circledast$ como suplementos energéticos não afetou a variação do escore de condição corporal, peso corporal, produção de leite, concentrações de ácidos graxos livres e parâmetros reprodutivos. 


\section{REFERÊNCIAS BIBLIOGRÁFICAS}

ASSOCIATION OF OFFICIAL ANALYTICAL CHEMISTS. Official methods of analysis of the AOAC. 15.ed. Washington: AOAC, 1985. 1015p.

AHIMA, R.S.; PRABAKARAN, D..M. C.; QU, D.L.B.; MARATOS-FILER, E.F. J.S. Role of leptin in the neuroendocrine response to fasting. Nature, v.382, p. 250-252, 1994.

ALLRICH, R. D. Endocrine and neural control of estrus in dairy cows. Journal of Dairy Science, v.77 n.9, p.2738-2744, 1994.

AMSTALDEN, M.; GARCIA, M. R.; WILLIAMS, S. W.; STANKO, R. L.; NIZIELSKI, S. E.; MORRISON, C. D.; KEISLER,D. H.; WILLIAMS, G.L. Leptin gene expression, circulating leptina, and luteinizing hormone pulsatility are acutely responsive to short-term fasting in prepuberal heifer : relationships to circulating insulin and insulin-like growth factor I. Biological of Reproduction, v.63, n.1, p.127-133, 2000.

ANDERSON, L. Subclinical ketosis in dairy cows. Veterinary Clinics of North America, v.4, p.233-252, 1988.

ANDERSSON, L.; EMMANUELSON, $U$. An epidemiological study of hyperketonemia in swedish dairy cows: determinants and the relation to fertility. Preventive Veterinary Medicine, v.3, p.449, 1985.

ANDERSON, L.; GUSTAFSSON, A.H.; EMANUELSON, U. Effect of hiperketonaemia and feeding on fertility in dairy cows. Theriogenology, v.36, p.521-536, 1991.

ANDREW,S. M.; WALDO, D. R.; ERDMAN, R. A. Direct analysis of body composition of dairy cows at three physiological stages. Journal of Dairy Science, v.77, n.10, p.3022-3033, 1994. 
ARAÚJO, P.G.; PIZZELLI, G.N.; CARVALHO, M.R. Involução uterina e atividade ovariana na vaca leiteira após o parto. Pesquisa Agropecuária Brasileira, v.9, n.7,p.1-6, 1974.

ARBEL, R.; BIGUN, Y. ; EZRA, E. ; STURMAN, H. ; HOJMAN, D. The effect of extended calving intervals in hight - yielding lactating cows on milk production and profitability. Journal of Dairy Science, v.84, n.3, p.600-608, 2001.

ARTHUR, G. H. Veterinary reproduction and obstetrics. 6.ed. London: Baillieri Tindall, 1989. 641p.

AYALON, N. A review of embrionic mortality in cattle, Journal Reproduction and Fertility, v.54, n.2, p.483-493, 1978.

AYALON, N. The repeat- breeder cow. In: INTERNATIONAL CONGRESS ON ANIMAL REPRODUCTION \& ARTIFICIAL INSEMINATION, 10., Urbana, 1984. Proceedings. Urbana: University of Illinois, 1984. p.317.

BAGNATO, A; OLTENACU, P. A phenotipic evaluation of fertility traits and their association with milk production of Italian friesian cattle. Journal of Dairy Science, v.77, n.3, 874-882, 1994.

BAIRD, G. D. Primary ketosis in the hight producing dairy cow: clinical and subclinical disorders, tretment, prevention and outlook. Journal of Dairy Science, v.65, n.1, p.1-10, 1982.

BALDWIN, R. L. JESSE, B. W. Propionate modulation of ruminal ketogenesis. Journal of Animal Science, v.74, p.1694-1700, 1996.

BALL, L.; OLSON, J.R.; MORTIMER, R.G. Therapeutic consideration for the pospartum bovine uterus. Society Theriogenologist News, v.7, p.4-5, 1984.

BAR, A.; PERRLMAN, R. ; SACHS, M. Observation on the use of alfhahydroxy vitamin $D^{3}$ in the prevention of bovine parturient paresis: the effect of a single injection on plasma 1-Alfhahydroxvitamin $D^{3}, 1,25$ - Dihydroxvitamin $D^{3}$, Calcium, and Hydroxyproline. Journal of Dairy Science, v.68, n.8,19521958, 1985.

BARR, H. L. Influence of estrus detection on days open in dairy herds. Journal of Dairy Science, v.58, n.2,p.246, 1975. 
BATAJOO, K. K.; SHAVER, R. D. Impact of non-fiber carbhydrate on intake, digestionn and milk production by dairy cows. Journal of Dairy Science, v.77, n.6, p.1580-1588, 1994.

BAUCHART, D. Lipid absorption and transport in ruminants. Journal of Dairy Science, v.76, n.12, p.3864-3881, 1993.

BAUMAN, D. E. ; CURRIE, W. B. Partitioning of nutrients during pregnancy and lactation: A review of mechanisms involving homeostasis and homeorhesis. . Journal of Dairy Science, v.63, n.9, p.1514-1529, 1980.

BEAL, W. E.; SHORT, R. E.; STAIGMILLER, R. B.;BELLOWS, R. A; KALTENBANCHC. C.; DUNN,T. G. Influence of dietary energy intake on bovine pituitary and luteal function. Journal of Animal Science, v.46, p.181-188, 1978.

BEAM, S. W.; BUTLER, W. R. Energy balance and ovary follicle development prior to first ovulation pospartum in dairy cows receiving three levels of dietary fat. Biology Reproduction, v.56, p.133-142, 1997.

BEAM, S. W.; BUTLER, W. R Energy balance, metabolic hormones, early pospartum follicular development in dairy cows fed prilled lipid. Journal of Dairy Science, v.81, n.1, p.121-131, 1998.

BELL, A W. Regulation of organic nutrient metabolism during transition from late pregnancy to early lactation. Journal of Animal Science, v.73, n.9, p.2804-2819, 1981.

BENDIXEN, P. H.; VILSON, B.; EKESBO, I. ASTRAND, D. B. Disease frequencies in dairy cows in Sweden. IV. Ketosis. Preventive Veterinary Medicine, v.5, p.99-109, 1987.

BERGER, P. J. ; SHANKS, R. D.; FREEMAN, A .E. Genetics aspects of milk yield and reproductive performance. Journal of Dairy Science, v.64, n.1,p.114, 1981.

BERTICS, J. S.; GRUMMER, R. R.; CADORNIGA - VALINO, C.; STODDARD, E. E. Effect of prepartum dry matter intake on liver triglyceride concentration and early lactation. Journal of Dairy Science, v.75, n.7, p.1914-1922, 1992.

BIGRAS-POULIN, M. A .; MEEK, A .H.; MARTIN, S. W. Interrelationships of health problems and age on milk production in selected Ontario holstein cows. Preventive Veterinary Medicine, v.8, p.3-13, 1990. 
BIRCHEN, M.; FADL-ALLA, B. A .; MURPHY, M. R.; McCOY, G. C.; HUTJENS, M. F. Metabolic effects of propylene glycol in transition diets of jersey cows. Journal of Animal Science, v.78, suppl.1, p.253, 2000.

BLACHE, D.; CELI, P. ; BLACKBERRY, A ; DYNES R. A ; MARTIN, G. B. Decrease in voluntary feed intake and pulsatile luteinizing hormone secretion after intracerebroventricular infusion of recombinant bovine leptine in mature male sheep. Reproduction Fertility and Development, v.12, n.7,8, p.373381, 2000.

BLANC, F.; MARTIN, G. B.; BOCQUIER, F. Modelling reproduction in farm animals: A review. Reproduction Fertility and Development, v.13, n.5,6, p.337-353, 2001.

BLOCK, E. Manipulating dietary anions and cations for prepartum dairy cows to reduce incidence of milk fever. Journal of Dairy Science, v.67, n.12, p.2939-, 1984.

BLUM, J. W.; REDIN, T.; JANS, F.; WANNER,, M.; ZEMP, M.; BACKMANN, K. Variations of 3-methylhistidine in blood of dairy cows. Journal of Dairy Science, v.68, n.10, p.2580-2587, 1985.

BONCZECK, R.R.; YOUNG, C. W.; WHEATON, J.E.; MILLER, K.P. Response of somatotropin, insulin, prolactin, and thyroxine to selection for milk yield in holsteins. Journal of Dairy Science, v.71, n.9, p.2470-2478, 1988.

BOYD, G. W.; KISER, T. E.; COWREY, R. S. Effect of prepartum energy intake on steroid during late gestation and on cow and calf performance. Journal of Animal Science, v.64, n.3, p.1703-1709, 1987.

BREMMER, D.R.; CHRISTENSEN, J.O.; GRIMMER, R.R.; RASMUSSEN, F.E.; WILTBANK, M.C. Effects of induced parturition and estradiol on feed intake, liver triglyceride concentration, and plasma metabolites of transition dairy cow. Journal of Dairy Science, v.82, n.7, p.1440-1448, 1999.

BRITT, J. H. Influence of nutrition and weight loss on reproduction and early embryionic death in cattle.In: WORLD BUIATRICS CONGRESS, 17., 1992. Proceedings. v.2, p.143-149.

BRITT, J.H. Follicular development and fertility: Potential impacts of negative energy balance. In: NATIONAL REPRODUCTION SYMPOSIUM, Pittsburgh, 1994. v.2, p.103-112 
BRITT, J.H; SCOTT,R. G.; ARMSTRONG, J. D.; WHITACRE, M. D. Determinants of estrus behavior in lactating Holstein cows. Journal of Dairy Science, v.62, p.2195-2202, 1986.

BROSTER,W.H.; BROSTER, V. J. Reviews of the progress of dairy science: long term effects of plane of nutrition on the performance of the dairy cow. Journal of Dairy Research, v.51, p.149-196, 1984.

BUCLKLEY, F.; DILLON,P.; RATH, M.; VEERKAMP,R.F. The relationship betwen genetic merit for yield and live weight, condition score, and energy balance of spring calving holstein friesian dairy cows on grass based system of milk production. Journal of Dairy Science, v.3, n.8, p.1878-1886, 2000.

BUTLER, W. R. Nutitional interaction with reproductive performance in dairy cattle. Animal Reproduction Science, v.60, n.1, p.449-457, 2000.

BUTLER, W. R.; CANFIELD, R. W. Interrelationships between energy and postpartum reproduction. In: CORNELL NUTRITION CONFERENCE, ITHACA,1989. Proceedings. p.66.

BUTLER, W. R.; SMITH, R. D. Interrelationships between energy balance and pospartum reproductive function in dairy cattle. Journal of Dairy Science, v.72, p.762-783, 1989.

BUTLER, W. R.; EVERETT,R. W.; COPPOK, C. E. The relationship between energy balance, milk production and ovulation in pospartum holstein cows. Journal of Animal Science, v.53, n. 3, p.742-748, 1981.

CANFIELD, R. W.; BUTLER, W. R. Energy balance and pulsatile luteinizing hormone secretion in early postpartum dairy cows. Domestics Animal Endocrinology, v.7, p.323- 1990.

CANFIELD, R. W.; SNIFFEN, C. J.; BUTLER, W. R. Effects of excess degradable protein on postpartum reproduction and energy balance in dairy cattle. Journal of Dairy Science, v.73, n.9, p.2342-2349, 1990.

CARSTAIRS,J.A.; MORROW,D, A.; EMERY, R. S. Postpartum reproductive function of dairy cows as influencied by energy and phosphorus status. Journal of Animal Science, v.51, n.5, p.1122- 1130, 1980.

CASIDA, L. E. Present status of the repeat- breeder cow problem. Journal of Dairy Science, v.44, n.2, p.2323-2329, 1961. 
CASTILLO, O. A. C. Aspectos bioquimícos do sangue e do leite de vacas leiteiras no início da lactação. Belo Horizonte, 1994. Dissertação (Mestrado)- Universidade Federal de Minas Gerais.

CHASE, L. A. Developing nutrition programs for high producion dairy herds. Journal of Dairy Science, v.76, n.10, p.3287-3283, 1993.

CHEW, D.P.; ERB, R.E.; FESSLER, J.F., CALLAHAM, C.J. MALVEN, P.V. Effect of ovarioectomy during pregnancy and prematurely induced parturition on progesterone, estrogens and calving traits. Journal of Dairy Science, v.62, p.557, 1979.

CHRISTENSEN, J. O.; GRUMMER, R.R.; RASMUSSEN, F. E.; BERTICS, J.S. Effect of method of delivery of propylene glycol on plasma matabolites of feed - restricted cattle. Journal of Dairy Science, v.80, n.3, p.563-568, 1997.

$\mathrm{CHURCH}, \mathrm{D}$. C. The ruminant animal digestive physiology nutrition. New York: Prentice Hall, 1988. 564p.

COLEMAN, D.A.; THAYNE, W.V.; DAILEY, R.A. Factors affecting reproductive performance of dairy cows. Journal Dairy Science, v.68, n.7, p.1793-2003, 1985.

COLLARD, B.L.; BOETTCHER, P.J.; DEKKERS, J.C.M.; PETICLERC, D.; SCHAEFFER, L. R Relationships between energy balance and health traits of dairy cattle in early lactation. Journal of Dairy Science, v.83, n.11, p.2683-2690, 2000.

CONSIDINE, R.V.; SINHA, M.K.; HEIMAN, M. L.; KRIAUCIUNAS,A.; STEPHENS, T.W.; NYCE, M.R.; OHANNESIAN, J.P.; MARCO, C.C.; McKEE, L. J.; BAUER, T.L.; CARO, J.F. Serum immunoreactive - leptin concentration in normal- weight and obese humans. New England Journal of Medicine, v.334, p.292-295, 1996.

COPPOCK, C.E.; NOLLER, C.H.; WOLFE, S.A; CALLAHAN, C.J.; BACKER, J.S. Effect of forage: concentrate ratio in complete feeds fed ad libitum on feed intake prepartum and the occurence of abomasal displacement in dairy cows. Journal of Dairy Science, v.55, n.6, p.783-, 1972. 
CUMMING, I.A; MOLE, B.J.; OBST, J.; DE, M.A; BLOCKEY, B.; WINFIELD, C. G.; GODING, J.R. Increase in plasma progesterone caused by undernutrition during early pregnancy in the ewe. Journal Reproduction and Fertility, v.24, n.1, p.146-147,1971.

CUNNINGHAN, M.J.; CLIFTON, D.K. ; STEINER, R.A. Leptin's action on the reproductive axis: perspectives and mechanisms. Biological of Reproduction, v. 60, p.216-222, 1999.

CURTIS, C.R.; ERB, H.N. Path analysis of dry period nutrition, pospartum metabolics and reproduction disorders, and mastitis in holstein cows. Journal of Dairy Science, v.68, n.9, p.2347-2360, 1985.

CURTIS, C.R. ; ERB, H.N.; SNIFFEN, C.J.; SMITH, R.D. Epidemiolgy of parturient paresis: predisposing actors with mphasis on dry cow feeding and management. Journal of Dairy Science, v.67, n.4, p.817, 1984.

CURTIS, C.R.; ERB, H.N.; SNIFFEN, C.J.; SMITH, R.D.; POWERS, P.A.; SMITH, M.C.; WHITE, M.E.; HILLMAN, R.B.; PEARSON, E.J. Association of parturient hypocalcemia with eight periparturient disorders in Holstein cows. Journal of American Veterinary Medicine Association, v.183, p.559, 1983.

DARWASH, A.O.; LAMMING, G.E.; WOOLLIAMS, J.A. Estimation of genetic variation in the interval from calving to postparrtum ovulation of dairy cows. Journal of Dairy Science, v.80, n.6, p.1227-1234, 1997.

DE KRUIF, A . Factors influencing the fertility of a catle population. Journal of Reproduction and Fertility, v.54, n.2, p.507-518, 1978.

DE KRUIF, A. The fertility of a cattle population. In: ONGRESSO BRASILEIRO DE REPRODUÇÃO ANIMAL, 10., Belo Horizonte, 1993. Anais. Belo Horizonte: Colégio Brasileiro de Reprodução Animal. 1993.

DE VRIES, M.J. ; VEERKAMP, R.F. Energy balance of dairy cattle in relation to milk production variables and fertility. Journal of Dairy Science, v.83, n.1, p.62-69, 2000.

DE VRIES, M.J.; VAN DER BEEK, S.; KAAL-LANSBERGEN, L.M.T.E; OWELTJES, W.; WILMINK, J.B.M. Modeling of energy balance in early lactation and the effect on energy deficits in early lactation on first detected estrus pospartum in dairy cows. Journal of Dairy Science, v.82, n.9, p.1927-1934, 1998. 
DELL'ORTO, V.; AGAZZI, A.; MANCINI, G.; SAVOINI, G. Transition cow: adminitration of glucose precursors and probiotics. Journal of Animal Science, v.78, suppl. 1, p.253, 2000.

DEWHURST, R.J.; MOORBY, J.M.; DHANOA, M.S.; FISHER, W.J. Effects of level of concentrate feeding during the second gestation of holstein-frisian dairy cows. 1. Feed intake and milk production. Journal of Dairy Science, v.85, n.1, p.169-177, 2002.

DHALIWAL, G.S.; MURRAY, R.D.; DOBSON, H. Effects of milk yield, and calving to first service interval, in determining herd fertility in dairy cows. Animal Reproduction Science, v.41, n.2, p.109-117, 1996.

DHALIWAL, G.S.; MURRAY, R.D.; WOLDEHIWET, Z. Some aspects of immunology of the bovine uterus related to tratments for endometritis. Animal Reproduction Science, v.67, n.1,2, p.135-152, 2001.

DIJKHUIZEN, A.A.; STELWAGEN, J.; RENKEMA, J.A. Economic aspects of reproductive failure in dairy cattle. I. Financial loss at farm level. Preventive Veterinary Medicine, v.3, p.251-263, 1985.

DIRKSEN, G.U.; LIEBICH, H.G.; MAYER, E. Adaptive changes of the ruminal mucosa and their functional and clinical significance. Bovine Practitioner, v.20, p.116-120, 1985.

DISHINGTON, I.W. Prevention of milk fever (hypocalcemic paresis puerperalis) by dietary salt supplements. Acta Veterinaria Scandinavica, v.16, p.503, 1975.

DOHI, H.; YAMADA,A; TSUDA,S.; SUMIKAWA,T.; ENTSU, S. Thecnical Note: A pressure sensitive sensor for measuring the caracteristics of standing mounts of cattle. Journal of Animal Science, v.71, n.2, p.369-372, 1993.

DOHOO, I.R., MARTIN, S.W. Subclinical ketosis: Prevalence and ssociations with production and isease. Canadian Journal of Comparative Medicine, v.48, p.1-15, 1984.

DOMECQ, J.J.; SKIDMORE, A.L.; LLOYD, J.W.; KANEENE, J.B. Relationship between body condition scores and milk yield in large dairy herd of high yielding Holstein cows. Journal of Dairy Science, v.80, n.1, p.101-112, 1997. 
DON ASLSUP; SCHALATTER, L. Parity differences in a controlled nutrocal study in a California dairy. Des Moines: Kemin Industries 1998. p.1-4 (Technical Information).

DRACKLEY, J.K. What about testing for blood NEFA levels in fresh cows? Hoard's Dairyman. v.144, n.19, p.783, 1999.

DRACKLEY, J.K. Biology of dairy cows during the transition period: The final frontier? Journal of Dairy Science, v.82,n.11, p.2259-2273, 1999.

DRACKLEY, J.K; RICHARD, M.J.; BEITZ, D.C.; YOUNG, J.W. Metabolic changes in dairy cows with ketonemia in response to feed restriction and dietary 1,3-butanediol. Journal of Dairy Science, v.72, n.6, p.1622-1634, 1992.

DRANSFIELD, M B.; NEBEL,R.L.; PEARSON, R.E.; WARNICK, L.D. Timing of insemination for dairy cows identified in estrus by a radiotelemetric estrus detection systems. Journal of Dairy Science, v. 81, n.7, p.1874-1882, 1998.

DUBOIS, M.; SCHLATTER, L. Efficacy of nutroCAL feed to a herd whose pre-fresh ration in formulated to minimize certain metabolic disorder at transition. Des Moines: Kemin Industries, 1997. p.1-4 (Thecnical Information).

DUCKER, M.J.; HAGGET, R.A; FISHER, W. J.; MORANT, S.V.; BLOOMFIELD, G.A Nutritional and reproductive performance of dairy cattle. 1. The effect of level of feeding in late pregnancy and around the time of insemination on the reproductive performance of first lactating dairy heifers. Animal Production, v.41, n.1, p.1-12, 1985.

DUFFIELD, T.F.; SANDALS, D.; LESLIE, K.E.; LISSEMORE, K.; McBRIDE, B.W.; LUMSDEN, J.H.; DICK, P.; BAGG, R. Efficacy of monensine fo the prevention for the prevention of subclinical ketosis in lactating dairy cows. Journal Dairy Science, v.81, n.11, p.2866-2873, 1998b.

DYK, P.B.; EMERY, R.S.; LIESMAN, J.L.; BUCHOLTS, H.F.; VANDERHAAR, M.J. Prepartum non-esterified fatty acids in plasma are higher in cows developing peripartum health problems. Journal of Dairy Science, v.75, suppl. 1, p.279, 1995. 
EDGERTON, L.A.; HAFS, H.D. Serum luteinizing hormone, prolactin, corticoid, and progestin in dairy cows from calving to gestation. Journal of Dairy Science, v. 56, n.4, p.451-458, 1973.

EDUVIE, L.O. Factors affecting pospartum ovarium activity and uterine involution in Zebu cattle Indigeneous of Nigeria. Animal Reproduction Science, v.8, p.123-128, 1985.

EMANUELSON, U.; OLTENACU, P.A.; GROHN, Y.T. Non linear mixed model analyses of five production disorders of dairy cattle. Journal of Dairy Science, v. 76, n. 9, p.2765-2772, 1993.

EMERY, R.S. Energy needs of dry cows. In: TRI-STATE DAIRY NUTRITION CONFERENCE, 35., Ames, 1993. Proceedings. Wayne: PURDUE UNIVERSITY, 1993.

EMERY, R.S.; BURG, N.; BROWN, L. D.; BLANK, G. N. Detection, occurence and prophylatic treatment of borderline ketosis with propylene glycol feeding. Journal of Dairy Science, v.47, n.2, p.1074- 1079, 1964.

ERB, R.E.; GOODWIN, M.M.; MORRISON, R.A.; SHAW, A.O. Lactation studies. Effect of gestation. Journal of Dairy Science, v.35, p.224, 1952.

ESSLEMONT, R.J.; BRYANT, M.J. Oestrus behavior in a herd of dairy cows. Veterinary Record, v.99, p.472, 1976.

ESSLEMONT, R.J.; KOSAIBATI, M.A. Decision support systems for fertility management in dairy herds: past, present and future. In: NOTTINGHAN CATTLE FERTILITY CONFERENCE,1996. Controlling fertility in dairy cows: proceedings. Journal of Animal Breeding, v.2, p.17-35, 1998.

ETHERTON, T.D.; BAUMAN, D.E. Biology of somatotropin in growth and lactation of domestic animals. Physiology Review, v.78, p.745-761, 1998.

FAUST, M.A.; McDANIEL, B.T. ; ROBINSON, O.W.; BITT, J.H. Environmental and yield effects on reproduction in primiparous Holsteins. Journal of Dairy Science, v.71, n.11, p.3092- 1988.

FERGUSON, J.D. Nutrition and reproduction in dairy cows. In: The Veterinary Clinics of North America: Food Animal Practice- Dairy Nutrition Management, v. 7, n.2, p.483-507, 1991. 
FERGUSON, J.D. Yield and reproduction in dairy cows. Bovine Practice, v.28, p.79-82, 1994.

FERGUSON, J.D. Componentes de um programa reprodutivo para rebanhos leiteiros. In: SIMPÓSIO INTERNACIONAL SOBRE PRODUÇÃO INTENSIVA DE LEITE, São Paulo, 1995. Anais. São Paulo, 1995. p.25-44.

FERGUSON, J.D.; CHALUPA, W. Impact of protein nutrition on reproduction in dairy cows. Journal of Dairy Science, v.72, n.3, p.746-766, 1989.

FERREIRA, A.M. Novos conceitos sobre o anestro pós-parto. In: CONGRESSO BRASILEIRO DE REPRODUÇÃO ANIMAL,10.,Belo Horizonte, 1995. Belo Horizonte, 1995. p.62-70

FERREIRA, A.M.; SÁ, W.F.; VILA, C.H.A.; ASSIS, A.G. Diagnóstico da situação produtiva e reprodutiva em rebanhos leiteiros da zona da Mata-MG. Congress. Bras. Medicina Veterinária, Belém, PA. v.19, p.61, 1984.

FERREL, C.L. Nutritional influences on reproduction. In : Cupps, P. T. Reproduction in domestics animals. 4. ed. New York: Academic Press, 1991. 567-603.

FINN, P.D.; CUNNINGHAN, M.J.; PAU, K.Y.F.; SPIES, H.G.; CLIFTON, D.K.; STEINER, R.A. The stimulatory effects of leptin on the neuroendocrine reproductive axis of the monkey. Endocrinology, v.139, p. 4652-4662, 1998.

FISCHER, L.J.; ERFLE, J.D.; LODGE, G.A.; SAUER, F.D. Effects of propylene glycol or glicerol supplementation of the diet of dairy cows on feed intake , milk yield and composition, and incidence of ketosis. Canadian Journal of Animal Science, v.53, n.2, 289-296, 1973.

FONSECA, F.A.; BRITT, J.H.; McDANIEL, B.T.; WILK, J.C.; RAKES A.H. Reproductive traits of holsteins and jersey. Effects of age, milk yield, and clinical abnormalities on involution of cervix and uterus, ovulation, estrous cycles, detection of estrus, conception rate, and days open. Journal of Dairy Science, v.66, n.5, p.1128-1147, 1983.

FONSECA, L.F.L. Suplementação de propileno glicol para vacas leiteiras periparturientes: Efeitos sobre o metabolismo, condição corporal, produção e reprodução. São Paulo, 1997. 114p. Dissertação (Doutorado)-Faculdade de Medicina Veterinária Universidade de São Paulo. 
FOOTE, R.H.; RIEKC, P.M. Gonadotropin-releasing hormone improve reproductive performance of dairy cows with slow involution of the reproductive tract. Journal Animal Science, v.77, n.1, p.12-16, 1999.

FORMIGONI, A.; CORNIL, M.C., PRANDI, A., MORDENTI, A. , ROSSI, A., PORTETELLE, D.; RENAVILLE, R. Effect of propylene glycol supplementation around parturition on milk yield, reproduction performance and some hormonal and metabolic characteristics in dairy cows. Journal of Dairy Research, v.63, p.11-24, 1996.

FRICKE, P.M.; WILTBANK, M.C. Effect of milk production on the incidence of double ovulation in dairy cows. Theriogenology, v.52, p.1133-1143, 1999.

FRONK, T.J.; SCHULTZ, L.H.; HARDIE, A.R. Effect of dry period overfeeding on subsequent metabolic disorders and performance of dairy cows. Journal of Dairy Science, v.63, n.7, p.1080-1090, 1980.

FULKERSON, W.J. Reproduction in dairy cattle: effect of age, cow condition, production level, calving-to-first service interval and the male. Animal Reproduction Science, v.7, p.305-314, 1984.

FUNK, D.A. Optimal genetic improvement for the high producing herd. Journal of Dairy Science, v.76, n.10, p.3278 - 3286, 1993.

FUNK, D.A.; FREEMAN, A.E.; BERGER, P.J. Effects of previous days open, previous days dry, and present days open on lactation yield. Journal of Dairy Science, v.70, n.11, p.2366- 2373, 1987.

GARCIA, M.; LARSSON, K. Clinical findings in pospartum dairy Cows. Nordisk Veterinary, v.34, p.255-263, 1982.

GARNSWORTHY, P.C. The effect of energy reserves at calving on performance of dairy cows. In: Garnsworthy, P.C., Nutrition and lactation in the dairy cow. London: Butterworth, 1988.

GARNSWORTHY, P.C.; JONES, G.P. The influence of body condition at calving and dietary protein supply on voluntary food intake and performance in cows. Animal Production, v.44, n.3, p.347- 353, 1987.

GARNSWORTHY, P.C.; TOPPS, J.H. The effects of body condition of dairy cows at calving on their food intake and performance when given complete diets. Animal Production, v.35, p.113-119, 1982. 
GARVERICK, H.A.; SMITH, M.F. Female reproductive physiology and endocrinology in cattle. Veterinary Clinic of North America, v.9, p. 223, 1993.

GAYNOR, P.J.; ERDMAN, R.A .; TETER, B.B.; SAMPUGNA, J.; CAPUCO, A.V.; HAMOSH, M. Milk fat yield and composition during abomasal infusion of cis or trans octadecenoatos in holstein cows. Journal of Dairy Science, v.77, p.157-165, 1994.

GEARHART, M.A.; CURTIS, C.R.; ERB, H.N.; SMITH, R.D.; SNIFFEN, C.J.; CHASE, L.E.; COOPER, B.D. Relationship of changes in condition score to cow health in holsteins. Journal of Dairy Science, v.73, n.11, p. 31323140, 1990.

GERLOFF, B.J.; HRDT, T.H.; EMERY, R.S. Relationship of hepatic lipidosis to health and performance in dairy cattle. Journal of American Veterinary Medical Association, v.188, p.845, 1986.

GIBB, M.J.; IRVINGS, W.E.; DANOA, M.S.; SUTTON, J.D. Changes in body components of autumm-calving holstein friesan cows over the first 29 weeks of lactation. Animal Production, v.55, n.3, p.339-360, 1992.

GILLUND, P.; REKSEN, O.; GRÖHN, Y.T.; KALBERG, K. Body condition related to ketosis and reproductive performance in Norwegian dairy cows. Journal of Dairy Science, v.84, n.6, p.1390-1396, 2001.

GOFF, J.P.; HORST, R.L. Effect of subcutaneously released 24f-1, 25hydroxyvitamin $D^{3}$ on incidence of parturient paresis in dairy cows. Journal of Dairy Science, v.73, n.2, p.406, 1990.

GOFF, J.P.; HORST, R.L. Calcium salts for treating hypocalcemia: Carrier effects, acids-base balance, and oral versus rectal administration. Journal of Dairy Science, v.77, n.7, p.1451, 1994.

GOFF, J.P.; HORST, R.L. Physiological changes at parturition and their relationship to metabolic disorder. Journal of Dairy Sience, v.80, p.126068, 1997.

GOFF J.P.; LITTLEDIKE, E.T.; HORST, R.L. Effect of synthetic bovine parathyroid hormone in dairy cows: prevention of hypocalcemic parturient paresis. Journal of Dairy Science, v.69, p.2278, 1986. 
GOFF, J.P.; HORST, R.L.; JARDON, P.W.; BORELLI, C.; WEDAM, J. Field trials of an oral calcium propionate paste as an aid to prevent milk fever in periparturient dairy cows. Journal of Dairy Science, v.79, n.3, p.378-383, 1996.

GOMBE, S.; HANSEL, W. Plasma luteinizing hormone (LH) and progesterone levels in heifers on restricted energy intakes. Journal of Animal Science, v.37, n.3, p.728-733, 1973.

GONZALEZ, S.W.J.P.; SOBRINHO, B.E.; GONÇALVES, A.A.M. Involução uterina de um rebanho Gir leiteiro segundo o período pós-parto e o número de parições. Arquivo Brasileiro de Medicina Veterinária e Zootecnia, v.51, n.4, p.345-351, 1999.

GRANOWITZ, E. Transforming growth factor-beta enhanced and proinflamatory citkines inhibit ob gene expression in the 3t3-LI adipocytes. Biochemical and Biophysic Research Community, v.240, p.382-385, 1997.

GRANT, R.J.; ALBRIGHT, J.L. Feeding behavior and management factors during the transition period in dairy cattle. Journal of Animal Science, v.73, n.9, p.2791-2803, 1995.

GREEN, B.L.; McBRIDE, B.W.; SANDALS, D.; LESLIE, K.E.; BAGG, R.; DICK, $P$. The impact of a monensin controlled-realease capsule on subclinical ketosis in the transition dairy cow. Journal of Dairy Science, v.82, n.2, p.333-342, 1999.

GREEN, H.B.; HORST, R.L.; BEITZ, D.C.; LITTLEDIKE, E.T. Vitamin D metabolites in plasma of cows fed a prepartum low calcium diet for prevention of parturient hypocalcemia. Journal of Dairy Science, v.64, n.2, p.217, 1981.

GREENFIELD, R.B.; CECAVA, M.J. ; JHONSON, T.R.; DONKIN, S.S. Impact of dietary protein amount and rumen undegradability on intake, peripartum liver triglyceride, plasma metabolites, and milk production in transitional dairy cattle. Journal of Dairy Science, v.83, n.4, p.703-710, 2000.

GRIFFIN, J.F.T.; HARTIGAN, P.J.; NUNN, W.R. Non-specific uterine infection and bovine fertility. 1.Infection patterns and endometritis during the first 7 weeks postpartum. Theriogenology, v.1, p.91-106, 1974. 
GRUMMER, R.R. Etiology of lipid-related metablic disorders in periparturient dairy cows. Journal of Dairy Science, v.76, n.12, 3882-3886, 1993.

GRUMMER, R.R. Impact of changes in organic nutrient metabolism on feeding the transition dairy cow. Journal of Animal Science, v.73, p.2820$2833,1995$.

GRUMMER, R.R. Transition cow energy, protein nutrition examined. Feedstuffs, Sept., 1998.

GRUMMER, R.R.; BERTICS, S.J.; HACKBART, R.A. Short communication: Effects of prepartum milking on dry matter intake, liver triglyceride, and plasma constituints. Journal of Dairy Science, v.83, n.1, p.60-61, 2000.

GRUMMER, R.R.; WINKLER, J.C.; BERTICS, S.J.; STUDER, V.A. Effect of propylene glycol dosage during feed restrition on metabolites in blood of prepartum holstein heifers. Journal of Dairy Science, v.77, n.12, p.36183628, 1994.

GUARD, C. Metabolic diseases : A herd approach. In: REBHUM, W. C.; GUARD, C.; RICHARD, C. M. Disease of dairy cattle. New York: Williams \& Wilkins, 1995. p.497-510.

GUSTAFSSON, A.H.; ANDERSSON, L.; EMANEELSSON, U. Effect of hiperketonemia, feeding frequency and intake of concentrate and energy on milk yeld in dairy cows. Animal Production, v.56, n.1, p.51-60, 1993.

HAFEZ, E.S.E. Reprodução animal. 6.ed., São Paulo: Editora Manole, 1995 $582 p$.

HALLGREN, W. Profhylaxis of milk fever using oral calcium chloride solutions. Tieraerstl, v.52, p.359, 1965.

HANSEN, L.B. ; FREEMAN, A.E.; BERGER, P.J. Yield and fertility relationship in dairy cattle. Journal of Dairy Science, v.66, n.2, p.293, 1983.

HENSON, J.E.; SCHINGOETHE, D.J.; MAIGA, H.A. Evaluation of protein supplement of varying ruminal degradabilities. Journal of Dairy Science, v.80, p.385-392, 1997.

HARDIN, D.K. Fertility and infertility assessement by review of records. Veterinary Clinic of North America, v.9, p.389, 1993. 
HARMON, D.L. Impact of nutrition on pancreatic exocrine and endocrine secretion in ruminants: a review. Journal of Animal Science, v.70, p.12901301, 1992.

HARRISON, L.M.; RANDEL, R.D. Influence of insulin and energy intake on ovulation rate, luteinizing hormone and progesterone in beef heifers. Journal of Animal Science, v.63, p.1228-1235, 1986.

HARRISON, R.O.; YOUNG, J.W.; FREEMAN, A.E.; FORD, S.P. Effect of lactation level on reactivation of ovarian function and intervals from parturition to first visual oestrus and conception in higt producing holstein cows. Animal Production, v.49, p.23-28, 1989.

HARRISON, R.O.; FORD, S.P.; YOUNG, J.W.; CONLEY, A .J.; FREEMAN, A. $E$. Increasing milk production versus reproductive energy status of high milk producing dairy cows. Journal of Dairy Science, v.73, p.2759, 1990.

HERDET, T.H. Fuel homeostasis in the ruminant. metabolic diseases of ruminant livestock. Veterinary Clinics of North America, v.4, n.2, p.213, 1988.

HEUER, C.; Van STRAALEN, W.M.; SCHUKKEN, Y.H.; DIRKZWAGER, A.; NOORDHUIZEN, J.P.T.M. Prediction of energy balance in high yielding dairy cows with test- day information. Journal of Dairy Science, v.84 , n.2, p.471-481, 2001.

HEUER, C.; SCHUKKEN, Y.H.; DOBBELAAR, P. Pospartum body condition score and results fro the first test day milk as predictors of disease, fertility, yield, and culling in commercial dairy herds. Journal of Dairy Science, v.82, n3, p.295-304, 1999.

HEUWUIESER, W.; FERGUSON, J.D.; GUARD, C.L.; FOOT, R.H.; WARNICK, L.D.; BREICKNER, L.C. Relationship betwen administrattion of $\mathrm{GnRH}$, body condition score and fertility in holstein dairy cattle. Theriogenology, v.42, p.703-714, 1994.

HEW, B. P.; ERB, R. E.; FESSLER, J.F.; CALLAHAN, C. J.; MALVEN, P.V. Effect of ovariectomy during pregnancy and prematurrely induced parturition on progesterone, estrogens, and calving trait. Journal of Dairy Science, v. 62, p.557, 1979.

HIBBIT, A.G. Bovine ketosis and its prevention. Veterinary Record, v.7, p.1315, 1979. 
HOLCOMB, C.S.; VAN HORN, H.H. ; HEAD, H.H.; HALL, M.B. ; WILCOX, C.J. Effects of prepartum dry matter intake and forage percentage on pospartum performance of lactating dairy cows. Journal of Dairy Science, v.84, n.9, p.2051-2058, 2001.

HOLMANN, F.J.; SHUMWAY, C.R.; BLAKE, R.W.; SCHWART, R.B.; SUDWEEKS, E.M. Economic value of days open for holstein cows of alternative milk yield with varying calving intervals. Journal of Dairy Science, v.67, n.3, p.636-643, 1984.

HOLTER, J.B.; SLOTNICK, M.J.; HAYES, H.H.; BOAK,C.K.; URBAN JR, W.E.; McGILLARD, M.L. Effect of prepartum dietary energy on condition score, pos partum energy, nitrogen partition, and lactation production responses. Journal of Dairy Science, v.73, n.12, p.3502-3511, 1990.

HORINO, M.J.; MACHLIN,F.; HERTELENDY, F.; KIPNIS, D.M. Effect of shortchain fatty acids on plasma insulin in ruminant and não ruminant species. Endocrinology, v.83 p.118, 1968.

HORST, R.L. , GOFF, J.P., REINHARDT, T.A. Calcium and vitamin D metabolism in the dairy cow. Journal of Dairy Science, v.77, n.7, p.19361951, 1994.

HUSSAIN, A.M.; DANIEL, R.C. W.; O'BOYLE, D. Postpartum uterine flora folowing normal and abnormal puerperium in cows. Theriogenology, v.34, p.291-302, 1990.

JASTER, E.H.; WEGNER, T.N. Beta-Adrenergic receptor involvement in lipolysis of dairy cattle subcutaneous adipose tissue during dry and lactating state. Journal Dairy of Science, v.64, n.8, p.1655-1663, 1981.

JOHNSON, G.; PEHRSON, B. Trials with prophylactic treatment of parturient paresis. Veterinary Record, v. 87, p.575, 1970.

JOHNSON, R. B. The treatment of ketosis with glycerol and propylene glycol. Cornell Veterinarian, v.40, p. 6-11, 1954.

JORDAN, E.R. ; FORUDRAINE, R.H. Characterization of the management practices of the top milk producing herds in the country. Journal of Dairy Science, v.76, n.10, p.3247-3256, 1993. 
JORRITSMA, R.; JORRITSMA, H.; SCHUKKEN, Y.H.; WENTINK, G.H. Relationship between fatty liver and fertility and some periparturient diseases in commercial dutch dairy herds. Theriogenology, v.54, p.1065-1074, 2000.

JOURMENT, M.; REMOND, B. Physiological factors affecting the voluntary intake of feed by cows: a review. Livestock Production Science, v.3, p.129, 1976.

JUCHEM, S.O. Suplementação de propileno glicol e monensina sódica para vacas no período de transição. Piracicaba, 2000. 99p. Dissertação (Mestrado) - Escola Superior de Agricultura "Luiz de Queiroz", Universidade de São Paulo.

KADOKAWA, H.; BLACHE, D.; YAMADA, Y.; MARTIN, G.B. Relationship between changes in plasma concentration of leptina before and after parturition and the timing of first postpartum ovulation in high producing holstein dairy cows. Reproduction Fertility and Development, v.2, n.7,8, p.405-411, 2000.

KAMIMURA, S.; OHGI, T.; TAKAHASHI, M.; TSUKAMOTO, T. Post-partum resumption of ovarian activity and uterine involution monitored by ultrasonography in holstein cows. Journal Veterinary Medicine Science, v.55, p.643-647, 1993.

KEADY, T.W.J. ; MAYNE, C.S. ; FITZPATRICK, D.A. ; McCOY, M.A. Effect of concentrate feed level in late gestation on subsequent milk yield, milk composition, and fertility of dairy cows. Journal of Dairy Science, v.84, n.6, p.1468-1479, 2001.

KEPPLE, B.B.; AIELLO, R.J.; GRUMMER, R.R.; ARMENTANO, L.E. Triglyceride accumulation and very low density lipoprotein secretion by rat and goat hepatocyte in vitro. Journal of Dairy Science, v.71, n.7, p.18131822, 1988.

KLINGBORG, D.J. Normal reproductive parameters in large "california-Style" dairies. Veterinary Clinics of North America: Food Animal Pracrice, v.3, n.3, p.483-494, 1987.

KOMARAGIRI, M.; ERDMAN, R.A. Prediction of body tissue mobilization in the dairy cow. In: MARLAND NUTRITION CONFERENCE FOR FEED MANUFECTURERS, Maryland, 1995. Proceedings. 
KUNZ, P.L.; BLUM, J.W.; HART, I.C.; BICKEL, H; LANDIS, J. Effects of different energy intakes before and after calving on food intake, perfomance and blood hormones and meta bolites in dairy cows. Animal Production, v.40, n.2, p.219-224, 1985.

KUZMA, R.; ROMANUIK, J. Treatment of cystic ovarian disease ( COD ) in cows with low fertility. II. The influence of some factors on the treatment efficacy. Bulletin of the Veterinary Institute in Pulawy, v.38, n.1, p.31-37, 1994.

LABEN, R.C.; SHANKS, R.D.; BERGER, P.J.; FREEMAN, A.E. Factors affecting milk yield and reproductive performance. Journal of Dairy Science, v.65, n.6, p.1004-1015, 1982.

LAGO, E.P. Avaliação da incidência de cetose em vacas leiteiras. Piracicaba, 1997. 88p. Dissertação (Mestrado) - Escola Superior de Agricultura "Luiz de Queiros", Universidade de São Paulo.

LAMMING, G.E.; DARWASH, A.O. The use of milk progesterone profiles to characteristic components of subfertility in milked dairy dairy cows. Animal Reproduction Science, v.52, n.3,4, p.175-190, 1998.

LAMMING, G.E.; WHATHYES, D.C.; PETERS, A.R. Endocrine patterns of the pospartum cow. Journal Reproduction and Fertility. v.30, p.155, 1982. Supplement.

LAMOND, D.R. The influence of undernutrition on reproduction in the cow. Animal Breeding Abstracts, v.38, p.359-372, 1970.

LARA, J.L.R. Alguns aspectos reprodutivos de um rebanho leiteiro no período pós-parto. Arquivo Brasileiro de Medicina Veterinária Zootecnia, v.38, p.228-231, 1986.

LEAN, I.J.; BRUSS, M.L.; BALDWIN, R.L.; TROUTT, H.F. Bovine ketosis: 1 Epidemiology and pathogenesis. Veterinary Bulletin, v.61, p.1209-1218, 1991.

LEE, J.K.; Van RADEN, P.M.; NORMAN, H.D.; WIGGANS, G.R.; MEINERT, T.R. Relationship of yield during early lactation and days open during current with 305 - day yield. Journal of Dairy Science, v.80, n.4, p.771776, 1997. 
LEWIS, G.S.; THATCHER, W.W.; BLISS, E.L.; DROST, M.C.R.J. Effects of heat stress during pregnancy on pospartum reproductive changes in Holstein Cows. Journal of Animal science, v.58, n.1, p.174-186, 1984.

LODGE, G.A.; FISHER, L.J. , LESSAD, J.R. Influence prepartum feed intake on performance of cows fed ad libitum during lactation. Journal of Dairy Science, v.58, n.5, p.696- 1975.

LOEFFLER, S.H.; DE VRIES, M.J.; SCHUKKEN, Y.H. The effects of time of disease ocurrence, milk yield, and body condition on fertility of dairy cows. Journal of Dairy Science, v.82, n.12, p. 2589-2604, 1999.

LUCY, M.C. Regulation of ovarian follicular growth by somatotropin and insulinlike growth factors in cattle. Journal of Dairy Science, v.83, p.1635-1647, 2000.

LUCY, M.C. ADSA foundation Scholar Award. Reproductive loss in highproduction dairy cattle: Where will it end ?. Journal of Dairy Science, v.84,n.6, p.1277-1293, 2001.

LUCY, M.C.; BOYD, C.K.; KOENIGSFELD, A.T.; OKAMURA, C.S. Expression of somatotropin receptor messenger ribonucleic acid in bovine tissues. Journal of Dairy Science, v.81, p.1889-1895, 1998.

LUCY,M.C.; STAPLES; C.R.; MICHEL, F.M.; THATCHER, W.W. Energy Balance and zise and number of ovarian foliicles detected by ultrasonography in early pos partum dairy cows. Journal of Dairy Science, v.74, n.2, p.473-482, 1991.

LUCY, M.C.; STAPLES, C.R.; THATCHER, W.W.; ERICKSON, P.S.; CLEALE, R.M.; FIRKINS, J.L.; CLARCK, J.H.; MURPHY, M.R.; BRODIE, B.O. Influence of diet composition, dry-matter intake, milk production and energy balance on time of pospartum ovulation and fertility in dairy cows. Animal Production, v. 54, p.323-331, 1992a.

LUNDEEN, T. Selenium injection innefective long term, NEFA monitors body score. Feedstuffs, p.8, June 2001.

MACLACHAN, N.J.; CULEN, J.M. Fígado, sistema biliar e pâncreas exócrino. In: THOMPSON, R. G. Patologia veterinária especial. São Paulo: Manole, 1990. cap. 5, p.265-308. 
MAGALHÃES, A.C.M.; BELÉM, P.A.D. Estudo preliminar sobre ocorrência de cetose subclínica em rebanho leiteiro. In: ENCONTRO NACIONAL DE PATOLOGIA VETERINÁRIA, 7., Goiania,1995. Anais. 1995.

MALVEN, P.V. Pathophysiology of the puerperium: definition of the problem. In: INTERNATIONAL CONGRESS ON ANIMAL REPRODUCTION \& ARTIFICIAL INSEMINATION, 10., Urbana, 1984. Proceedings. Urbana: University of Illinois, 1984. p.317.

MANN, G.E.; LAMMING, G.E.; ROBINSON, R.S.; WATHES, D.C. The regulation of interferon-tau production and uterine hormone receptors during early pregnancy. Journal Reproduction and Fertility. v.54, p.317-328, 1999. Supplement.

MANNS, J.G.; HUMPHREY, W. D.; FLOOD, P.F.; MAPLETOFT, R.J.; RAWLINGS, N.; CHENG, K. W. Endocrine profiles and functional characteristics of corpora lutea following onset of postpartum ovarian activity in beef cows. Canadian Journal of Animal Science, v.63, n.2, p.331-347, 1983.

MANNS, J.G.; BODA, J.M. Insuline release by acetate, propionate, butyrate, and glicose in lambs and adult sheep. American Journal of Physiology, v.212, p.747, 1967.

MOALLEN, U.; KAIM, M.; FOLMAN,Y.; SKLAN, D. Effect of calcium soaps of fatty acids and administration of somatotropin in early lactation on preoductive and repeoductive performance of high producing cows. Journal of Dairy Science, v.80,n.9, p.2127-2136, 1997.

MAPLEDSEN, D.D. Propylene glycol in the treatment of ketosis. Canadian Journal of Comparative Medicine and Veterinary Science, v.18, p.287293, 1954.

MARION, G.B.; GIER, H.T. Factors affecting bovine ovarian activity after parturition. Journal of Animal Science, v.27, p.1621-1626, 1968.

MARION, G.B.; NORWOOD, J.S., GIER, H.T. Uterus of the cow after parturition: fators affeting regression. Animal Journal Veterinary Research, v.29, p.71-75, 1968.

MARKUSFELD, O ; GALON, N. ; EZRA, E. Body condition score, health, yield and fertility in dairy cows. Veterinary Records, v.141, p.67-72, 1997. 
MASHEK, D.G.; BEEDE, D.K. Peripartum responses of dairy cows to partial substituition of corn grain in diet fed during the late period. Journal of Dairy Science, v.83, n.10, p.2310-2018, 2001.

MASHEK, D.G.; RODRIGUEZ, L.; BEEDE, D.K. We're learning more about fresh cow strategy. Hoard's Dairyman, v.142, n.18, p.737, 1997.

MCENTEE, K. Reproductive pathology of domestic mammals. San Diego: Academic Press, 1990.

McMILLAN, K.L.; LEAN, J.J.; WEASTWOOD, C.T. The effects of lactation on the fertility of dairy cows. Australian Veterinary Journal, v.73, p.141-147, 1996.

MENGE, A.C.A.C.; MARES, S.E.; TYLER, W.J.; CASIDA, L.E. Variation and association among post partum reproduction and production caracteristics in holstein friesian cattle. Journal of Dairy Science, v.45, n.1, p.233-241, 1962.

MERTENS, D.R. Predicting intake and digestibility using mathematical models of ruminant function. Journal of Animal Science, v.64, p.1548-1558, 1987.

MIYOSHI, S.; PATE, J.L.; PALMQUIST, D.L. Effects of propylene glycol drenching on energy balance, plasma glucose, plasma insulin, ovarian function and conception in dairy cows. Animal Reproduction Science, v.68, n.1,2, p.29-43, 2001.

MIYOSHY, S. Role of energy balance, plasma glucose and insulin on ovarian function and conception of dairy cows. Ames, 1995. 82p. Thesis (M.S.)-Ohio State University.

MORROW, D.A. Programed dairy herd health. Journal of Dairy Science, v.7, n.51, 1966.

MORROW, D.A. Fat cow syndrome. Journal of Dairy Science, v.59, n.9, p.1625-1629, 1975.

MORROW, D.A.; ROBERTS, S.J.; McENTEE, K. Postpartum ovarium activity and involution of the uterus and cervix. Cornell Veterinary, v.59, p.190-198, 1969. 
MUINGA, R.W.; THORPE, W.; TOPPS, J.H. Voluntary food intake, live weight change and lactation performance of crossbred dairy-cows ad-libitum pennisetum-purpureum. Animal Production, v.56, n.3, p.284-289, 1993.

NAGATANI, S.; ZENG, Y.; KEISLER, D.H.; FOSTER, D.L.; JAFFE, D.A. Leptin regulates pulsatile luteinizing hormone and growth hormone secretion in the sheep. Endocrinology, v.141, p.3965-3975, 2000.

NAGATANI, S.; GUTHIKONDA, P.; THOMPSON, R.C.; TSUKAMURA, H.; MAEDA , K.I.; FOSTER, D.L. Evidence for $\mathrm{GnRH}$ regulation by leptin: Leptin administration prevent reduced pulsatile $\mathrm{LH}$ secretion during fasting. Neuroendocrinology, v.67, p.370-376, 1998.

NATIONAL RESEARCH COUNCIL. Nutrient requeriments of dairy cattle. Washington: National Academy of Science, 2001. 381p.

NEBEL, L.R.; McGILLARD, M.L. Interaction of hight yield and reproductive performance in dairy cows. Journal of Dairy Science, v.76, n.10, p.32573268, 1993.

NOGUEIRA, L.A.G.; PINHEIRO, L.E.L.; NORTE, A.L. Involução uterina e retorno a atividade ciclica ovariana em vacas Bos taurus indicus. Revista Brasileira de Reprodução Animal, v.17, n.1,2, p.49-56, 1993.

OLDS, D.; COOPER, T.; THRIFT, F.A. Effects of days open on economic aspects of current lactation. Journal of Dairy Science, v.62, n.7, p.11671170, 1979.

OLSON, D.J., SCHATTER, L. Field trial of nutrical in a Colorado dairy. Des Moines. Kemin industries, 1997. p.1-4(Technical information)

OLSON, J.D.K.; BRETZLAFF, N.; MORTIMER, R.G.; BALL, L. The metritispyometra complex in current therapy in theriogenology 2: diagnosis, treatment and prevention of reproductive diseases in small and large animals.., Philadelphia: W. B. Saunders, 1986. 735p.

OLSON.K. E. Economic, political, and global demands on the United States Dairy industry. Journal of Dairy Science, v.76, n.10, p. 3133-3142, 1993.

OLTENACU, P.A.; MILLIGAN, R.A.; ROUNSAVILLE, T.R.; FOOTE, R.H. Modelling Reproduction in a herd of dairy cattle. Agricutural Systems, v.5, p.193-205, 1980. 
OTT, R.L. An introduction to statistical methods and data analysis. Wadsworth: 1983.

OTTO, K.L.; FERGUSON, J.D.; FOX, D.G.; SNIFFFEN, C.J. Realtionship between BCS and composition of ninth to eleventh rib tissue in holstein dairy cows. Journal of Dairy Science, v.74, n.3, p.852-859, 1991.

OVERTON, T.R. You can manage the metabolism of fresh cows. Hoard's Dairyman, v.146, n.9, p.33, 2001.

PAISLEY, L.G.; MICKELSON, W.D.; ANDERSON, P.B. Mechanism and therapy for retained fetal membranes and uterin infection cows: a review. Theriogenology, v.25, p.353-381, 1986.

PEDRON, O., CHELI, F., SENATORE, E., BAROLI, D., RISSI, R. Effect of body condition score at calving on performance, some blood parameters, and milk fatty acid composition in dairy cows. Journal of Dairy Science, v.76, n.9, p.2528-2535, 1993.

PETERS, A.R.; LAMMING, G.E. Endocrine changes in the pospartum period. In: INTERNATIONAL CONGRESS ON ANIMAL REPRODUCTION \& ARTIFICIAL INSEMINATION, 10., Urbana, 1984. Proceedings. Urbana: University of Illinois, 1984. p.332.

PHILIPSON, J. Impact of international trade in cattle, semen and embryos on genetics evaluation. In: INTERNATIONAL DAIRY CONGRESS., 23., Montreal, 1990. Brussel: Int. Dairy Fed., 1990. p.644.

PULLEN, D.L.; PALMQUIST, D.L.; EMERY, R.S. Effect of days in lactation and methionine hydroxy analog on incorporation of plasma fatty acids into plasma triglycerides. Journal of Dairy Science, v.72, n.1, p.49, 1989.

RABELO, E.; BERTICS, S.J.; MACKOVIC, J.; GRUMMER, R.R. Strategies for increasing energy density of dry cow diets. Journal of Animal Science, v.84, n.10, p.2240-2249, 2001.

RABIEE, A.R.; LEAN, I.J.; GOODEN, J.M.; MILLER, B.G.; SCARAMUZI, J.R. An evaluation of transovarian uptake of metabolites using arterio-venous difference methods in dairy cattle. Animal Reproduction Science, v.48, n.1, p.9-25, 1997. 
RABIEE, A.R.; MACMILLAN, K.L.; SCHWARZENBERGER, F. The effect of level intake on progesterone clearence rate by measuring faecal progesterone metabolites in grazing dairy cows. Animal Reproduction Science, v.67, n.3-4, p.205-214, 2001.

RAO, C.C.; RAO, A.R. Invulation of genitalia of ongole crossbred cows. Indian Journal Animal Science, v.50, p.834-837, 1980.

REECE, W.O. Fisiologia dos animais domésticos. São Paulo: Ed. Roca, 1996.

REID, I.M., ROBERTS, C.J., TREACHER, R.J., WILLIAMS, L.A. Effect of body condition at calving on tissue mobilization, developement of fatty liver and blood chemistry of dairy cows. Animal Production, v.43, n.1, p.7, 1986.

REIST, M.; KOLLER, A.; BUSSATO, A.; KUPFER, U.; BLUM, J.W. First ovulation and ketone body status in the early postpartum period of dairy cows. Theriogenology, v.54, p.685-701, 2000.

REYNOLDS, C.K.; HARMON, D.L.; CECAVA, M.J. Absorption and delivery of nutrients for milk protein syntesis by portal-drained viscera. Journal of Dairy Science, v.77, n.9, p.2787-2808, 1994.

REYNOLDS, C.K.; HUNTIGNTON, G.B.; TYRRELL, H.F.; REYNOLDS, P.J. Net portal- drained visceral and hepatic metabolism of glucose, L-lactate and nitrogenous compounds in lactating holstein cows. Journal of Dairy Science, v.71, n.7, p.1803-1812, 1988.

RICHARDS, M.W.; SPITZER, J.C.; WARNER, M.B. Effect of varying levels of postpartum nutrition and body condition at calving on subsequent reproductive performance in beef cattle. Journal of Animal Science, v.62, n.1, p.300, 1986.

RINGARP, N.; RYDBERG, C.; DAMBERG, O; BOSTROM, B. The prophylaxis of milk fever in cattle by oral administration of calcium chloride gel. Veterinaermed, v.14, p.242, 1967.

RISCO, C.A.; MOREIRA, F.; THATCHER, W.W. In: AVANÇOS EM PRODUÇÃO E MANEJO DE BOVINOS LEITEIROS, Lavras, 2002. Lavras: UFLA, 2002. p.137-160. 
RISCO, C.A.; REYNOLDS, J.P.; HIRD, D. Uterine prolapse and hypocalcemia in Dairy Cows. Journal Americam Veterinary Medical Association, v.185, p.1517, 1984.

ROBERTS, S.J. Veterinary obstetrics and genital diseases. Theriogenology. Nort Pomfret: David and Charles, 1986. 258p.

ROCHE, J.F.; MACKEY, D.; DISKIN, M.D. Reproductive management of postpartum cows. Animal Reproduction Science, v.60-61, n.2, p.703-712, 2000.

ROSELER, K.D.; FOX, D.G.; DELL, A.N.; CHASE, L.E. Evaluation of alternative of equations for prediction of intake for holstein dairy cows. Journal of Dairy Science, v.80, n.5, p.864-877, 1997.

RUEGG, P.; GOODGER, W.J.; HOLMBERG, C.A.; WEAVER, L.D.; HUFFMAN, E.M. Relation among body condition score, serum urea nitrogen and cholesterol concentrations, and reproductive performance in high- producing holstein dairy cows in early lactation. American Journal of Veterinary Research, v.53, 1992.

RUEGSEGGER, G.J.; SCHULTZ, L.H. Use of a combination of propylene glycol and niacin for subclinical ketosis. Journal of Dairy Science, v.69, n.5, p.1411-1415, 1986.

RUFINO, L.; KREHBIEL, C.; KLOPPENBURG, P. Effects of nutrocal fed in a peripartum period on serum nutrient profiles and milk production in holstein cows. Des Moines: Kemin Industries, 1997. p.1-8. (Technical information)

RUKKWAMSUK, T.; WENSING, T.; MATT, G.J H. Effect of overfeeding during dry period on regulation of adipose of dairy tissue metabolism in dairy cows during the parturient period. Journal of Dairy Science, v.81, n.11, p.29042911, 1998.

RUKKWANSUK,T.; GEELEN, M.J.H.; KRUIP, T.A.M.; WENSING, T. Interrelation of fatty acid composition in adipose tissue, serum, and liver of dairy cows during the development of fatty liver pospartum. Journal of Dairy Science, v.83, n.1, p.52-59, 2000.

RUSSEL, J.M.; GALINA, C.S. Research and publishing trends in cattle reproduction in the tropics: Part 2. A third world prerrogative. Animal Breeding Abstracts, v.55, p.819-828, 1997. 
SAIDUDDIN, S.; RIESEN, J.W.; TYLER, W.J.; CASIDA, L.E. Some carry-over effects of pregnancy on pos-partum ovarian function in the cow. Journal of Dairy Science, v.50, p.1846-1847, 1967.

SANTOS, J. E. P. Efeito da nutrição sobre a reprodução em bovinos, Arquivos da Faculdade de Medicina Veterinária da UFRGS, v.26, Supl.1, p.18-89, 1998.

SANTOS, J.E.P. Effect of degree of fatness prepartum on lactational performance and follicular development of early lactation dairy cows. Tucson, 1996. 107p. Thesis (M.S.). University of Arizona, Tucson.

SANTOS, J.E.P.; SANTOS, F.A.P. Novas estratégias no manejo e alimentação de vacas pré-parto. In: SIMPÓSIO SOBRE PRODUÇÃO ANIMAL, 10., Piracicaba, 1998. Anais. Piracicaba: FEALQ, 1998. p.165-204.

SAS INSTITUTE. SAS user's guide: statistic. 5 ed., Cary, 1985.

SATURNINO, H.M. Puerpério na vaca. In: CONGRESSO BRASILEIRO DE REPRODUÇÃO ANIMAL, 8., Belo Horizonte, 1989. Anais. Belo Horizonte, 1989. p.198-205.

SAUER, F.D. Propylene glycol and glycerol as feed additive for lactating dairy cows: na evaluation of blood matabolite parameter. Canadian Journal of Animal Science, v. 53, n.2, p.265-271, 1973.

SCHAEFER, L.R.; HENDERSON, C.R. Effect of days dry and days open on holstein milk production. Journal of Dairy Science, v.55, n.1, p.107, 1972.

SCHINDLER, H.; EGER, S.; DAVIDSON, M.; OCHOSKI, D.; SCHEMERHORN, FOOTE, R.H. Factors affecting response of groups of dairy cows managed for different calving-conception intervals. Theriogenology, v.36, n.3, p.495503, 1991.

SCHIRAR, R.; MARTINET, J. Postpartum ovarian activity nad its interaction with the uterus in resuming cyclic activity postpartum. In: KARLBERG, H.; SCHALLEMBERGER, E. Factors influencing fertility in the pastpartum cow. The Hague: Martinus Nijhoff, 1982.

SCHLATTER, L. The addition of nutrocal to the diets of periparturient cows: A review. Des Moines: Kemin Industries, 1997. p.1-11. (Technical information) 
SCHNEIDER, F.; SHELFORD, J.A .; PETERSON, R.G.; FISHER, L.J. Effects of early and late breeding of dairy cows on reproduction and production in current and subsequent lactation. Journal of Dairy Science, v.64, n.10, p.1996-2002, 1981.

SENATORE, E.M.; BUTLER, R.W.; OLTENACU, P.A. Relatinships between energy balance and postpartum ovarianactivity and fertility in first lactation dairy cows. Journal of Animal Science, v.62, p.17-23, 1996.

SENGER, P.L. The estrus detection problem: New concepts, tecnologies, and possibilities. Journal of Dairy Science, v.77, p.2745, 1994.

SENGER, P.L.; HILLER, K.L.; MITCHELL, J.R.; FLEMING, W.N.; DARLINGTON, R.L. Effects of serum treated semen, bulls and herdsmeninseminator on conception to first service in large commercial dairy herds. Journal of Dairy Science, v.67, n.3, p.686-692, 1984.

SHAVER, R.D. Nutritional risk factors in the etiology of left displaced abomasum in dairy cows: A review. Journal of Dairy Science, v.80, n.10, p.2449-2453, 1997.

SINHA, M.K.; OPENTONAOVA, I.; IHANNESIAN, J.P.; KOLACZYNSKI, J.W.; HEIMAN, M.L.; HALE, J.; BECKER, G.W.; BOWSHER, R.R.; STEPHENS, T.W.; CARO, J.F. Evidence of free and bound leptin in human circulationstudies in lean and obese subjects and during short-term fasting. Journal Clinical Investigation, v.98, p.1277-1282, 1996.

SKLAN, D.; KAIM, M.; MOALLEM, U.; FOLMAN, Y. Effect of dietary calcium soaps on milk ybody weight, reproductive hormones, and fertility in first parity and older cows. Journal of Dairy Science, v.77, n.6, p.1652-1660, 1994.

SLAMA, H.; WELLS, M.E.; ADAMS, G.D.; MORRISON, R.D. Factors affecting calving interval in dairy herds. Journal of Dairy Science, v.59, n.7, p.13341339, 1976.

SMITH, G.D.; JACKSON, L.M.; FOSTER, D.L. Leptin regulation on reproductive function and fertility. Theriogenology, v.57, n.1, p.73-86, 2002.

SMITH, M.C.A.; WALLACE, J.M. Influence of early post partum ovulation on the re establishment of pregnancy in multiparous and primiparous dairy cattle. Reproduction Fertility and Development, v.10, n.2, p.207-216, 1998. 
SNIJDERS, S.E.M.; DILLON, P.G.; O'COLLAGHAN, D.; BOLAND, M.P. Effect of merit, milk yield, body condiction and lactation number on in vitro oocyte development in dairy cows. Theriogenology, v.53, p.981-989, 2000.

SNIJDERS, S.E.M.; DILLON, P.G.; O'FARRELL, K.J.; DISKIN, M.; WILIE, A.R. G.; O'CALLAGHAN, D.; RATH, M.; BOLAND, M.P. Genetic merit for production and reproductive success in dairy cows. Animal Reproduction Science, v.65, n.1-2, p.17-31, 2001.

SOBERANES, J.A. Reproductive activity of the cows in the pós- partum period. I Factors the lenght of the post-partum acyclic period. British Veterinary Journal, v.140, p.76-84, 1989

SON, J.; GRANT, R.J.; LARSON, L.L. Effect oftallow and escape protein on lactation and reproductive performance of dairy cows. Journal of Dairy Science, v.79, n.5, p. 822-830, 1996.

SPALDING, R.W.; EVERETT, R.W.; FOOTE, R.H. Fertility in New York artificial inseminated holstein herds in dairy herd improvement. Journal of Dairy Science, v.58, n.5, p.718, 1975.

SPICER, L.J.; ENRIGHT, W.J. Concentration of insuline-like growth factor I and esteroids in follicular fluid of preovulatory bovine ovarian follicles: effects of daily injection of growth hormone-releasing hormone. Journal of Dairy Science, v.69, p.1133-1139, 1991.

SPICER, L.J.; TUCKER, W.B.; ADAMS, G.D. Insulin-like growth factor-I in dairy cows: Relationships among energy balance, body condition, ovarian activity, and estrous behavior. Journal of Dairy Science, v.73, n.4, p.929937, 1990.

SPICER, L.J.; ALPIZAR, E.; ECHTERNKAMP, E. Effects of insulin, insulin like growth factor I,and gonadotropins on bovine granulosa cell proliferation, progesterone production, estradiol production, and ( or ) insulin - like growth factor I production In Vitro. Journal of Animal Science, v.71, n.5, p.1232$1241,1993$.

STAPLES, C.R.; BURKE, J.M.; THATCHER, W.W. Influence of suplemental fats on reproductive tissues and performance of lactating cows. Journal of Dairy Science, v.81, n.3, p.856-871, 1998. 
STAPLES, C.R.; THATCHER, W.W.; CLARK, J.H. Relationship between ovarian activity and energy status during the early pospartum period of high producing dairy cows. Journal of Dairy Science, v.73, n.4, p.938-947, 1990.

STAPLES, C.R., THATCHER, W.W. Interactions between energy, production, and reproduction: today and tomorrow. In: TECHNICAL DAIRY SYMPOSIUM- DAIRY NUTRITION \& PRODUCTION, Phoenix, 1997. Proceedings. p.15-24.

STEPHENES, T.W.; BASINSKI, M.B.P.K.; BUE-VALLESKEY, J.M.B.S.G.; CRAFT, L.; HALE, J.H.J.; HSIUNG, H.M.; KRIAUCIUNAS, A.M.W.R.; Jr, P.R.S.; SMITH, D.T.F.C.; ZHANG, X.Y.; HEIMAN,M. The role of neuropepitide $\mathrm{Y}$ in the antiobesity action of the gene product. Nature, v.377, n.6549, p.530-532, 1995.

STEVENSON, J. Can you have good reproduction and high milk yield? Hoard's Dairyman, v.144, n.13, p. 536,1999.

STEVENSON, J.S.; BRITT, J.H. Relationship among luteinizing hormone, estradiol progesterone, glucocorticoids, milk yield, body weight and pospartum ovarian activity in holstein cows. Journal of Animal Science, v.48, n.3, p.570-577, 1979.

STEVENSON, J.S.; SCHMIDT, M.K.; CALL, E.P. Factors affecting reproductive performance of dairy cows first inseminated after five weeks postpartum. Journal of Dairy Science, v.66, n.5, p.1148-1154, 1983.

STOKES, R.S.; GOFF, J.P. Case study: evaluation of calcium propionate and propylene glycol administred in to esophagus of dairy cattle at calving. The Professional Animal Scientist, v.17, p.115- 122, 2001.

STUDER, V.A.; GRUMMER, R.R.; BERTICS, S.J. Effect of prepartum propylene glycol administration on periparturient fatty liver in dairy cows. Journal of Dairy Science, v.76, n.10, p.2931-2939, 1993.

STURMAN, H.; OLTENACU, E.A; FOOTE, R.H. Importance of insemination only cows in estrus. Theriogenology, v.53, p.1657-1667, 2000.

SVENNERSTEN-SAUNJA, K.; SJAUNJA, J.; BERTILSSON, J.; WIKTORSSON, $\mathrm{H}$. use of regular milking records versus daily records for nutrition and other kinds of management. Livestock Production Science, v.48, p.164-167, 1997. 
SWANSON, L.V. Discussion, interaction of nutrition and reproduction. Journal of Dairy Science, v.72, n.3, p.805-814, 1989.

TAMINGA, S.; LUTEIJN, P.A.; MEIJER, R.G.M. Changes in composition and energy content of liveweight loss in dairy cows with time after parturition. Livestock Production Science, v.52, p.31-38, 1997.

TESFA, A.T.; TUORI, M.; SYRJALA-QVIST, L.; POSO, R.; SALONIEMI, H.; HEINONEM, K.; KIVILAHTI, K.; SAUKKO,T; LINDBERG, L.A. The influence of dry period feeding on liver fat and pospartum performance of dairy cows. Animal Feed Science and Technology, v.76, p.275-295, 1999.

THATCHER, W.W.; WILCOX, C.J. Pospartum estrus as an indicator of repeodutive status in the dairy cow. Journal of Dairy Science, v.56, n.5, p.608-610, 1973.

TREACHER, R.J.; REID, I.M.; ROBERTS, C.J. Effect of body condition at calving on the health and performance of dairy cows. Animal Production, v.43, n.1, p.1-6, 1986.

USMANI, R.H.; AHMAD, N.; SHAFIQ, P.; MIRZA, M.A. Effect of subclinical uterine infection on cervical and uterine involution, estrous activity and fertility in postpartumk buffaloes. Theriogenology, v.55, p.563-571, 2001.

VAN SAUN, R.J. Dry cow nutrition; the key to improving fresh cow performance. Veterinary Clinics of North America, v.7, p.599, 1991.

VAN SAUN, R.J.; IDLEMAN, S.C. ; SNIFFEN, C.J. Effect of undegradable protein amount fed prepartum on pospartum production in first lactational holstein cows. Journal of Dairy Science, v.76, n.1, p.236-244, 1993.

VANDEPLASSCHE, M.; BOUTERS, R. Puerperal metritis in the bovine. In: INTERNATIONAL CONGRESS ON ANIMAL REPRODUCTION AND ARTIFICAL INSEMINATION, 4., Krakow, 1976. Proceedings. p.660-666. 
VANN DEN TOP, A .M.; WENSING, T.; GEELEN, M.J.H.; WENTINK, G.H.; VAN'KLOOSTER, A.T.; BEYNEM, A.C. Time trends of plasma lipids and enzimes synthesizing hepatic triacylglycerol during poatpartum development of fatty liver in dairy cows. Journal of Dairy Science, v.78, n.10, p.22082220, 1995.

VASCONCELOS, J.L.M.; SILVA, H.M.; REIS, R.B. Involução do sistema genital pós-parto de vacas Holandesaa cruzadas e puras por cruza. Arquivo Brasileiro de Medicina Veterinária e Zootecnia, v.45, n.4, p.405-418, 1993

VASCONCELOS, J.L.M. ; BUNGERT, K.A.; TSAI, S.J.; WECHSLER, F.S.; WILTBANK, M.C. Acute reduction in serum progesterone concentrations due to feed intake. Journal of Dairy Science, v.81, suppl.1, p. 226, 1998.

VASCONCELOS, J.L.M.; ESPER, C.R.; SANTOS, R.M.; VASCONCELOS, C. G.C.; WECHSLER, F.S. Detecção de subfertilidade em vacas leiteiras por meio de medidas anatômicas da região pélvica e do aparelho genital. Arquivos Brasileiro Medicina Veterinária e Zootecnia, v.52, n.5, p.468474, 2000.

VAZQUEZ-AÑON, M., BERTICS, S., LUCK, M., GRUMMER, R.R. Peripartum Liver Triglyceride and Plasma Metabolites in Dairy Cows. Journal of Dairy Science, v.77, n.6, p.1521, 1994.

VEENHUIZEN, J.J. ; DRACKLEY, J.K. ; RICHARD, M.J. SANDERSON, T.P.; MILLER, L.D.; YOUNG, J.W. Metabolic changes in blood and liver during development and early treatment of experimental fatty liver and ketosis in cows. Journal of Dairy Science, v.74, n.12, p.4238-4253, 1991.

VEENHUIZEN, J.J. Nutrition during dry period and hepatic Ipids metabolism of pre parturient dairy cows. Journal of Dairy Science. v.79, p.1850, 1996.

VEERKAMP, R.F.; BROTHERSTONE, S. Genetic correlations between linear type traits, food intake, live weight and condition score in Holstein Friesian dairy cattle. Animal Science, v.64, n.3, p.385-392, 1997

VEERKAMP, R.F.; KOENEN, E.P.C.; JONG, G. De. Genetic correlations among body condition score, yield, and fertility in first-parity cows estimated by random regression models. Journal of Dairy Science, v.84, n.10, p.2327-2335, 2001. 
VILLA-GODOY, A.; HUGHES, T.L.; EMERY, R.S.; CHAPIN, L.T.; FOGWEL, L. Association between energy balance and luteal function in lactating dairy cows. Journal of Dairy Science, v.71, n.4, p.1063-1072, 1988.

WALDO, D.R.; SCHULTZ, L.H. Blood and rumen changes following the intraruminal administration of glycogenic materials. Journal of Dairy Science, v.43, n.4, p.496-505, 1960.

WALKER, W.L.; NEBEL, R.L.; McGILLARD, M.L. Time of ovulation relative to mounting activity in dairy cattle. Journal of Dairy Science, v.79, n.9, p.1555-1561, 1996.

WEAVER, L.D. Managing body condition scores to maximize milk yield and reproduction. In: ANNUAL CONVENTION AABP, 24., Orlando, 1991. Proceedings.

WELSER, J.; SCHLATTER, L. Nutrocal's efficacy in reducing metabolic disorders in a michigan dairy; return on investment. Des Moines: Kemin Industries, 1997. p.1-4. (Technical information)

WEST, J.W. Body scoring tracks herd health and nutrition. Hoard's Dairyman, v.140, n.13, p.511, 1995

WETTEMAN, R.P. Postpartum endocrine funciton of cattle, sheep, and swine. Journal of Animal Science, v.51, p.2, suppl.2, 1980.

WIGGANS, G.R.; ERNST, C.A. Effects of genetic merit of sire for milk yield and herd yield level on reproductive traits. Journal of Dairy Science, v.70, Suppl.1, p.232, 1987.

WILDMAN, E.E., JONES, G.M., WAGNER, P.E., BOWMAN, R.L.,Jr.; TROUTT, H.F.; LESCH, T.N. A dairy cow body condition scoring system and its relationship selected production characteristics. Journal of Dairy Science, v.65, n.3, p.495-501, 1982.

WILTBANK, M.C. Regulation of the ovary in cattle. In: NOVOS ENFOQUES NA PRODUÇÃO E REPRODUÇÃO DE BOVINOS, Passos: CONAPEC Jr., 1998. p.1-13.

WILTBANK, M.C. Relação entre reprodução e nutrição em vacas de leite. In: NOVOS ENFOQUES NA PRODUÇÃO E REPRODUÇÃO DE BOVINOS, Uberlândia: CONAPEC Jr., 2002. p.15-23. 
WRIGHT, I.A.; RUSSEL, A.J.F. Partition of fat, body composition and body condition score in mature cows. Animal Production, v.38, n.1, p.23-32, 1984.

WRIGHT, I.A.; RHIND, S.M.; WHYTE, T.K. Effect of body condition at calvind and feeding level after calving on $\mathrm{LH}$ profiles and the duration of the pospartum anestrus period in beef cows. Animal Production, v.55, n.1, p.41-46, 1992.

YOUNG, J.W. Gluconeogenesis in cattle: significance and methodology. Journal of Dairy Science, v.60, n.1, 1977.

ZAMET, C.N.; COLEMBRANDER, V.F.; CALLAHAN, C.J.; CHEW, B.P.; ERB, R.E.; MOELLER, N.J. Variables associated with peripartum traits in dairy cows. I. Effects of dietary forages and disorders on voluntary intake of feed, body weight and milk yield. Theriogenology, v.11, p.229, 1979.

ZAMMITH, V.A. Ketogenesis in the liver ruminants- adaptation to a challenge. Journal of Agriculture Science, v.115, n.2, p.155-162, 1990.

ZHANG, Y.P.M.; BARONE, M.; LEOPOLD, L.; FRIEDMAN, J.M. Positional cloning of the mouse obese gene and its human homologue. Nature, v.372, p.425-432, 1994.

ZUREK, E.; FOXCROFT, G.R.; KENNELLY, J.J. Metabolic status and interval to first ovulation in postpartum cows. Journal of Dairy Science, v.78, n.9, p.1909-1920, 1995. 